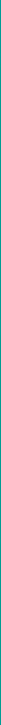

\title{
GEOPEDAGOGIA
}

A escola em mapas mentais de estudantes brasileiros, bolivianos e haitianos

Rosa Martins Costa Pereira Solimária Pereira Lima Zuíla Guimarães Cova dos Santos (Orgs.)

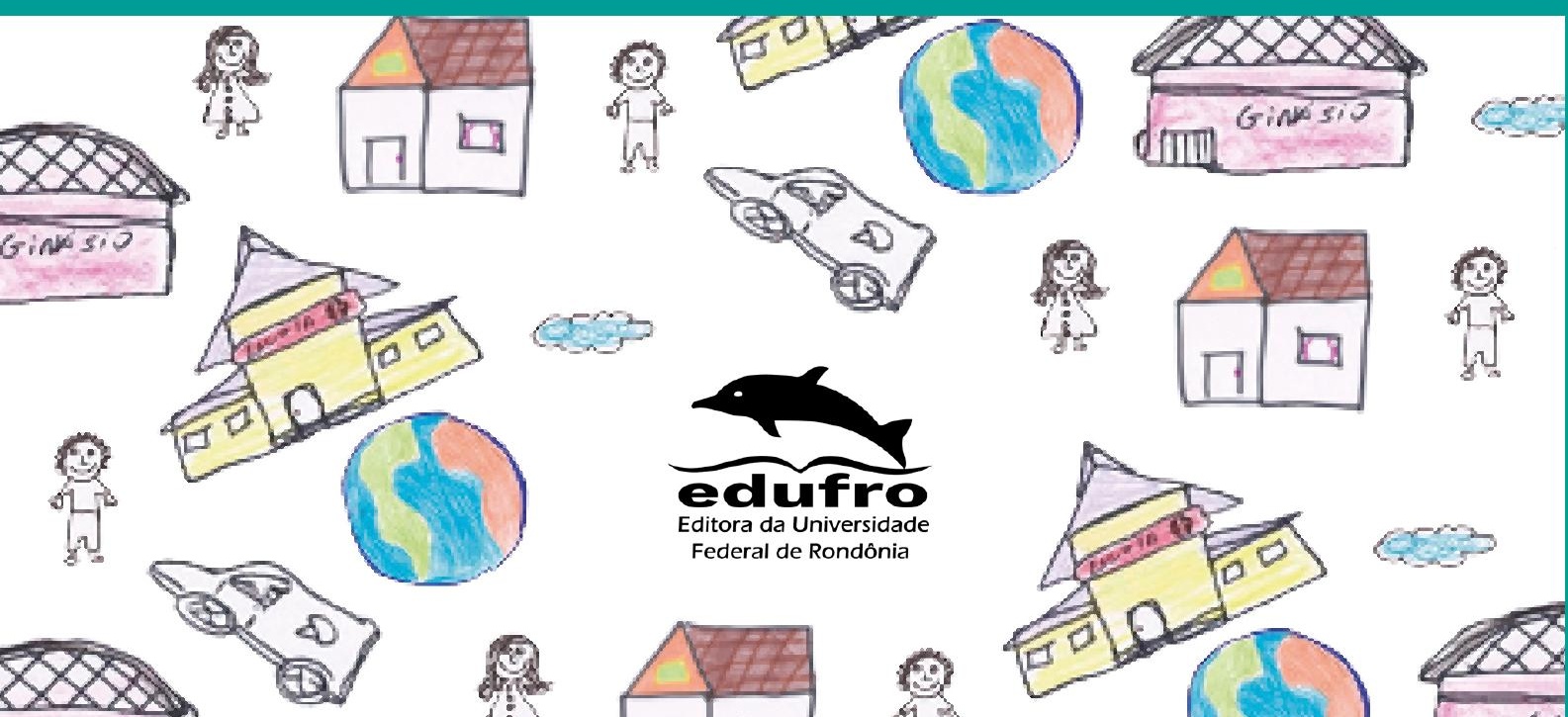




\section{GEOPEDAGOGIA: A ESCOLA EM MAPAS MENTAIS DE ESTUDANTES BRASILEIROS, BOLIVIANOS E HAITIANOS}

Rosa Martins Costa Pereira

Solimária Pereira Lima

Zuila Guimarães Cova dos Santos

(Organizadoras) 
Reitor Ari Miguel Teixeira Ott

Vice-Reitor José Juliano Cedaro

EDITORA DA UNIVERSIDADE FEDERAL DE RONDÔNIA

$\begin{array}{ll} & \text { CONSELHO EDITORIAL } \\ \text { Presidente } & \text { Lou-Ann Kleppa } \\ & \text { Ariana Boaventura Pereira } \\ \text { Carlos Alexandre Trubiliano } & \text { Eliane Gemaque Gomes Barros } \\ & \text { Gean Carla Silva Sganderla } \\ \text { Leandro Soares Moreira Dill } & \text { Márcio Secco } \\ & \text { Marli Lúcia Tonatto Zibetti } \\ & \text { Pedro Ivo Silveira Andretta } \\ & \text { Ricardo Gilson da Costa Silva } \\ & \text { Xênia de Castro Barbosa }\end{array}$

Editora Filiada
Edufro - Editora da Universidade Federal de Rondônia BR 364, Km 9,5
Campus Unir
76801-059 - Porto Velho - RO
Tel.: (69) 2182-2175
www.edufro.unir.br edufro@unir.br




\section{GEOPEDAGOGIA: A ESCOLA EM MAPAS MENTAIS DE ESTUDANTES BRASILEIROS, BOLIVIANOS E HAITIANOS}

Rosa Martins Costa Pereira

Solimária Pereira Lima

Zuila Guimarães Cova dos Santos

(Organizadoras)

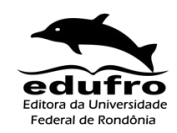

Porto Velho - RO 
(C) 2020 by Rosa Martins Costa Pereira, Solimária Pereira Lima, Zuila Guimarães Cova dos Santos (Organizadoras)

Esta obra é publicada sob a Licença Creative Commons Atribuição-Não

Comercial 4.0 Internacional.

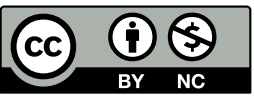

Capa:

Vitoria Gonçalves Morão

Revisão:

Dra. Jeane Mari Spera

Projeto gráfico:

Edufro - Editora da Universidade Federal de Rondônia

\author{
Diagramação: \\ Guilherme André de Campos \\ Impressão e acabamento: \\ Seike \& Monteiro Editora
}

Aprovado no Edital 02/2018/EDUFRO

Dados Internacionais de Catalogação na Publicação

Fundação Universidade Federal de Rondônia (UNIR)

Ficha Catalográfica elaborada pela Biblioteca Central da UNIR

F981 Fundação Universidade Federal de Rondônia.

Geopedagogia: a escola em mapas mentais de estudantes brasileiros, bolivianos e haitianos / organização Rosa Martins Costa Pereira; Solimária Pereira Lima; Zuila Guimarães Cova dos Santos. - Porto Velho, RO: EDUFRO, 2020.

182 p.; il.

ISBN: 978-65-87539-21-8 (físico)

ISBN: 978-6587539-13-3 (digital)

1. Escola. 2. Formação de professores. 3. Alunos imigrantes. 4. Mapas mentais. I. Pereira, Rosa Martins Costa. II. Lima, Solimária Pereira. III. Santos, Zuila Guimarães Cova dos. IV. Fundação Universidade Federal de Rondônia.

CDU 376-054.57 


\section{Sumário}

7

APRESENTAÇÃO

11

PARTE I

13

1. A REPRESENTAÇÃO DA ESCOLA: ESPAÇO DE SUBJETIVIDADES E ESCOLHAS

Zuila Guimarães Cova dos Santos

Irisneide Moraes da Silva Araújo

33 2. A ESCOLA NO HAITI EM MAPAS MENTAIS DE CRIANÇAS

Rosa Martins Costa Pereira

Patrícia Pereira da Silva

Samuel Dorvilus

Budiene Martins da Silva

Cledenice Blackman

55 PARTE 2

57 3. MAPAS MENTAIS E FORMAÇÃO DE PROFESSORES: REPRESENTAÇÕES DOS OLHARES DOS DISCENTES PARA A MATEMÁTICA

Gislaina Rayana Freitas dos Santos

77 4. A PERCEPÇÃO DA ESCOLA PELO ALUNO ATRAVÉS DOS MAPAS MENTAIS: VISANDO A SUPERAÇÕES E OPORTUNIDADES

Glauciane Sanches da Silva

Rosenete Salvatierra Marinho Niederauer

Elaine Márcia Souza Rosa 
99 5. ESPAÇO ESCOLAR E IDENTIDADE: ANÁLISE DE MAPAS MENTAIS DE ALUNOS DE UMA ESCOLA MUNICIPAL EM PORTO VELHO/RO

Solimária Pereira Lima

Ednalva Oliveira Silva

Geiza dos Santos Mendonça

Iza Reis Gomes Ortiz

123 6. A ESCOLA NA PERSPECTIVA DE ESTUDANTES: UM OLHAR SOB A LENTE DE MAPAS MENTAIS

Cláudia Gonçalves Barroso

Luanna Freitas Johnson

Thaís Alicea Brito

135 7. A ESCOLA E O PROCESSO DE HUMANIZAÇÃO DO ESTUDANTE

Beatriz Lima Costa

Iracema Neno Cecilio Tada

Luanna Freitas Johnson

149 8. A EDUCAÇÃO ESCOLAR DE ALUNOS IMIGRANTES EM DISSERTAÇÕES E TESES BRASILEIRAS E PORTUGUESAS: 0 DESAFIO DA INCLUSÃO DAS DIFERENÇAS

Lineu Norio Kohatsu

Maria da Conceição Pereira Ramos

Natália Ramos

177 Sobre as organizadoras

179 Sobre os/as autores/as 


\section{APRESENTAÇÃO}

Essa obra é fruto de um trabalho integrado entre pesquisadores de diferentes lugares e apresenta resultados do Projeto de Pesquisa "Geopedagogia: a escola em mapas mentais de alunos brasileiros, haitianos e bolivianos”, coordenado pela pesquisadora Dra. Rosa Martins Costa Pereira e vinculado ao Programa Institucional de Pesquisa do Instituto Federal de Educação, Ciência e Tecnologia de Rondônia (IFRO/CNPq), ciclo 2014-2015.

O objetivo da pesquisa foi conhecer representações sobre a escola de estudantes brasileiros, bolivianos e haitianos por meio de mapas mentais. $\mathrm{O}$ projeto envolveu duas formas de inserção de campo: o suporte teórico-metodológico da aplicação de mapas mentais, proposto pela pesquisadora Dra. Salete Kozel (UFPR) e a pesquisa de campo em Porto Velho com observação participante em uma escola estadual de ensino fundamental que acolhe imigrantes, em 7 (sete) salas de aula, durante 3 meses. Foram aplicados um total de 79 mapas mentais nos países Brasil, Bolívia e Haïti, sendo: 40 mapas em escolas brasileiras, nos municípios de Porto Velho e Guajará-Mirim; 20 mapas em uma escola boliviana, na cidade de Guayaramerín e 10 mapas em uma escola haitiana, nos arredores de Porto Príncipe, no Haiti.

A pesquisa é classificada como estudo de opinião pública com participantes não identificáveis, conforme Art. 1, Parágrafo Único, I da Resolução CNS N. 510/2016, sendo, portanto, dispensada apresentação de termos de consentimentos, o que a inviabilizaria, considerando ser um estudo internacional com execução em países e públicos distintos com os quais não se teria mais contato e, em muitas ocasiões, os responsáveis legais não seriam encontrados.

O principio teórico-metodológico foi a Teoria das Representações Sociais. As Representações Sociais se articulam à vida social de um grupo e também à construção simbólica do indivíduo em particular. É assim que damos sentido ao mundo, passamos a entendê-lo e buscamos encontrar o nosso lugar nele. 
A questão norteadora do estudo foi: o que é a escola para você? A partir dessa questão, os estudantes produziram mapas mentais e depois falavam sobre eles aos pesquisadores. Os estudantes receberam materiais para desenho e pintura.

O trabalho de campo e análises foi organizado em quatro grupos de trabalho cujos resultados compõem a estrutura desta obra.

Ao longo da presente obra, vinte e três autores trazem suas reflexões acerca dos mapas mentais produzidos. São autores comprometidos com estudos e ações no campo da educação e da imigração. Dentre as atividades que desenvolvem, há um ponto comum, que agrega os pesquisadores na proposta de conhecer e analisar as representações de diferentes nacionalidades sobre a educação escolar.

A obra é organizada em duas partes. A primeira parte é composta por dois capítulos que abordam questões mais amplas sobre educação e migração e sobre a função social da escola. A segunda parte expõe os resultados das análises de mapas mentais do Projeto Geopedagogia.

$\mathrm{Na}$ abertura da obra, o Capítulo I abre espaço para um novo contexto de análise, os mapas mentais produzidos no Estado Plurinacional da Bolívia, em específico, uma escola da cidade de Guayaramerín, no departamento do Beni. O texto traz uma reflexão acerca do mundo vivido da escola boliviana da periferia urbana à luz da percepção do aluno matriculado nos anos finais da Educación Secundária. Os mapas mentais imprimem sentimentos, ações e valores, são instrumentos catalizadores das relações sociais vividas no espaço. Quando aplicado em pesquisas educacionais, por exemplo, contribuem para compreendermos as relações entre os sujeitos escolares e seus processos de aprendizagem. A análise dos mapas mentais aplicados aos alunos bolivianos nos revelou a importância da formação técnica para estes jovens. Uma formação que para muitos alunos é o único caminho para uma melhor condição de vida.

No Capítulo II, o leitor terá a experiência de conhecer um pouco mais sobre a educação escolar haitiana e descobrir representações da escola na análise de mapas mentais de crianças, aplicados nos arredores de Porto Príncipe no ano de 2015. A pesquisa possibilitou, assim, a experiência de 
cartografar o que é a escola. No caso das crianças haitianas, ficou evidente que essa cartografia se expressa por meio das dificuldades de acesso à escola, assim como pelas experiências diversificadas em salas de aula multisseriadas, do pertencimento nacional em meio a ingerências de outras nacionalidades no território haitiano e da expectativa de inclusão social por meio da escola.

Ao longo do Capítulo III, os Mapas Mentais de alunos bolivianos são destaque. A autora traz o seu olhar sobre a formação docente e a educação matemática, apontando a importância da matemática no espaço escolar, como elo na formação profissional e cidadã do educando. No Capítulo IV, são analisados mapas mentais elaborados por alunos do município de Guajará-Mirim.

O Capítulo V aborda os mapas mentais de alunos haitianos matriculados em uma escola pública de Porto Velho, capital do estado de Rondônia. As autoras destacam que as representações construídas por estes alunos revelam o sentimento de alegria e pertencimento em relação ao ambiente escolar do qual fazem parte.

Ainda nesse caminho da análise dos mapas produzidos por alunos matriculados em instituições de ensino brasileiras, em específico nos municípios de Porto Velho e Guajará-Mirim no estado de Rondônia, temos o Capítulo VI, que apresenta a análise de cinco mapas produzidos por estudantes do ensino médio, brasileiros residentes em Guajará-Mirim. Os resultados foram analisados à luz das concepções de Saviani (1982; 2012) e das concepções de Mészáros (2005), os quais defendem que a escola tem função transformadora da sociedade, equalizando a desigualdade social. No entanto, observam que, desde sua origem, tem servido à ideologia dominante, reforçando o maquinário capitalista. A análise dos mapas aponta que, na perspectiva dos estudantes, a escola é um meio de ascensão social, um espaço de preparação para o futuro profissional, mas também de interação e aprendizagem, ou seja, eles não concebem a escola no mesmo contexto defendido pelos autores.

No Capítulo VII, as autoras apresentam um panorama da educação no Brasil, explicando como a escola é vista de maneira deturpada, apenas como um espaço para aprender conteúdos específicos que irão resultar 
no ingresso no mercado de trabalho. Destacam o papel do professor na formação crítica do aluno. Destacam as forças que estão além da escola, mas que interferem no seu dia-a-dia. $\mathrm{E}$ ainda, a interferência de acordos internacionais na elaboração destas políticas que pouco contribuem para o enfrentamento do fracasso escolar na educação básica.

Finalmente, o Capítulo VIII tem como objetivo comparar a produção acadêmica de universidades brasileiras e portuguesas sobre a educação escolar de alunos imigrantes. O levantamento bibliográfico foi realizado nos bancos de dissertações e teses da Universidade de São Paulo, da Pontifícia Universidade Católica de São Paulo, da Universidade do Porto, da Universidade Aberta e na Coleção de Teses do Observatório das Migrações - Alto Comissariado para as Migrações - ACM.

A leitura da obra pode ser realizada de forma pontual, com a alternância de capítulos. Contudo, na leitura de todas as partes, em um processo linear, o sentido dos textos fica melhor compreendido.

O Projeto GeoPedagogia nos aproximou de textos e contextos de estudantes de diferentes países em situação de migração ou com a experiência de morar em uma fronteira internacional.

As representações dos estudantes nos dizem que seu maior sonho é que a escola seja um espaço de interação e de inclusão social. Para muitos deles, representa a única esperança de melhorar suas condições de vida e de sua família por meio da formação técnica profissional, criando expectativa de aprender coisas que tenham sentido e de ser acolhido e respeitado em sua dignidade.

\author{
Rosa Martins Costa Pereira \\ Solimária Pereira Lima \\ Zuila Guimarães Cova dos Santos \\ Organizadoras
}


PARTE I 



\title{
1. A REPRESENTAÇÃO DA ESCOLA: ESPAÇO DE SUBJETIVIDADES E ESCOLHAS
}

\author{
Zuila Guimarães Cova dos Santos \\ Irisneide Moraes da Silva Araújo²
}

\section{Introdução}

O estudo aqui apresentado tem como referência as representações de alunos bolivianos sobre a escola. Esses alunos são residentes na cidade de Guayaramerín, que pertence ao Departamento do Beni na Bolívia e localiza-se na fronteira com a cidade brasileira de Guajará-Mirim, em Rondônia. As duas cidades são consideradas cidades-gêmeas devido à semelhança em seus processos históricos de criação, visto que ambas surgiram do ciclo da exploração da castanha, extração do látex e do processo de Implantação da Estrada de Ferro Madeira Mamoré. Ao longo da história das duas cidades, as relações políticas, econômicas, culturais e educacionais sempre estiveram presentes no modo de vida dessas comunidades fronteiriças.

É nesse espaço geográfico que a escola ganha atenção. Entender como os alunos pensam a escola foi o objetivo do projeto de pesquisa que deu origem a este artigo. Nesse sentido, optamos por desenvolver a metodologia dos Mapas Mentais para compreender as múltiplas relações entre o sujeito (educando) e a escola.

\footnotetext{
${ }^{1}$ Doutora em Geografia pela Universidade Federal do Paraná -UFPR, Mestre em Ciências da Linguagem pela Universidade Federal de Rondônia - UNIR, Pedagoga, Professora do Departamento de Ciências da Educação do campus de Guajará-Mirim-UNIR. Pesquisadora do Grupo de Pesquisa em Educação, Filosofia e Tecnologias GET/IFRO. Líder do Grupo de Estudos Interdisciplinares das Fronteiras Amazônicas - GEIFA/UNIR.

${ }^{2}$ Graduada em Pedagogia, Licenciatura Plena, pela Universidade Federal de Rondônia UNIR. Pós-Graduada em: Supervisão, Orientação e Gestão Escolar com ênfase Psicologia Educacional; Psicopedagogia Clínica e Institucional. Estudante pesquisadora do Grupo de Pesquisa em Educação, Filosofia e Tecnologias GET/IFRO
} 
Os mapas mentais são enunciados que apresentam uma interação verbal intensa, razão pela qual são representações que têm como base a inter-relação do indivíduo com o outro. Conforme Kozel e Galvão (2008), os mapas mentais são de fundamental importância como ferramenta na construção de diagnóstico relacionado a situações que envolvem a educação. São instrumentos catalisadores da manifestação do desenvolvimento cognitivo, social e cultural dos alunos.

Inicialmente apresentaremos uma breve caracterização histórica do surgimento das cidades-gêmeas. Descreveremos de forma breve o sistema de ensino público boliviano e, posteriormente, destacaremos o mundo vivido da escola boliviana, com base na análise das principais categorias que surgiram nas representações.

\section{A fronteira das cidades-gêmeas de Guajará-Mirim (Rondônia/Brasil) e Guayaramerín (Beni/Bolívia)}

O Brasil é um país que possui uma extensa área de fronteira com países da América do Sul; ao todo são dez países, ficam fora apenas o Chile e o Equador. A Bolívia possui a maior extensão de fronteira com o Brasil, no total são $3.126 \mathrm{~km}$ de fronteira que se localizam em diferentes estados: Acre, Rondônia, Mato Grosso e Mato Grosso do Sul.

O Tratado de Madri (1750), firmado entre espanhóis e portugueses, definiu, amistosamente, os limites entre as partes. Portugal abriu mão da Colônia de Sacramento (atual região do Uruguai) e a Espanha, por sua vez, entregou a região dos Sete Povos das Missões, atualmente o território correspondente aos estados de Santa Catarina, Mato Grosso do Sul, Amazônia e Rio Grande do Sul.

Entretanto, a fronteira de Rondônia (Brasil) foi delimitada um pouco mais tarde, através de acordos entre os colonizadores da América do Sul. Inicialmente, o Tratado de Ayacucho (1867) fixou os limites entre o Brasil e a Bolívia, e nesse acordo valia o princípio de uti possidetis, ou seja, as terras pertenciam a quem estivesse ocupando-as. Com esse acordo, os Portugueses demarcaram o limite territorial brasileiro, assentando, em 20 de 
junho de 1776, a pedra fundamental da construção do Real Forte Príncipe da Beira, situado às margens do rio Guaporé.

O rio Guaporé e o rio Mamoré representam o marco divisório da fronteira entre Rondônia, no território brasileiro, e o território boliviano. Os dois rios juntos fazem aproximadamente $1400 \mathrm{~km}$ de leito navegável nos limites entre o Brasil e a Bolívia. A cidade de Guajará-Mirim (Rondônia/ Brasil) situa-se à margem direita do rio Mamoré, e Guayaramerin (Beni/ Bolívia), à margem esquerda, conforme podemos observar no Mapa 1.

Mapa 1 - Localização geográfica da fronteira da cidades-gêmeas de Guajará-Mirim (RO/BR) e Guayaramerín (Beni/Bol).

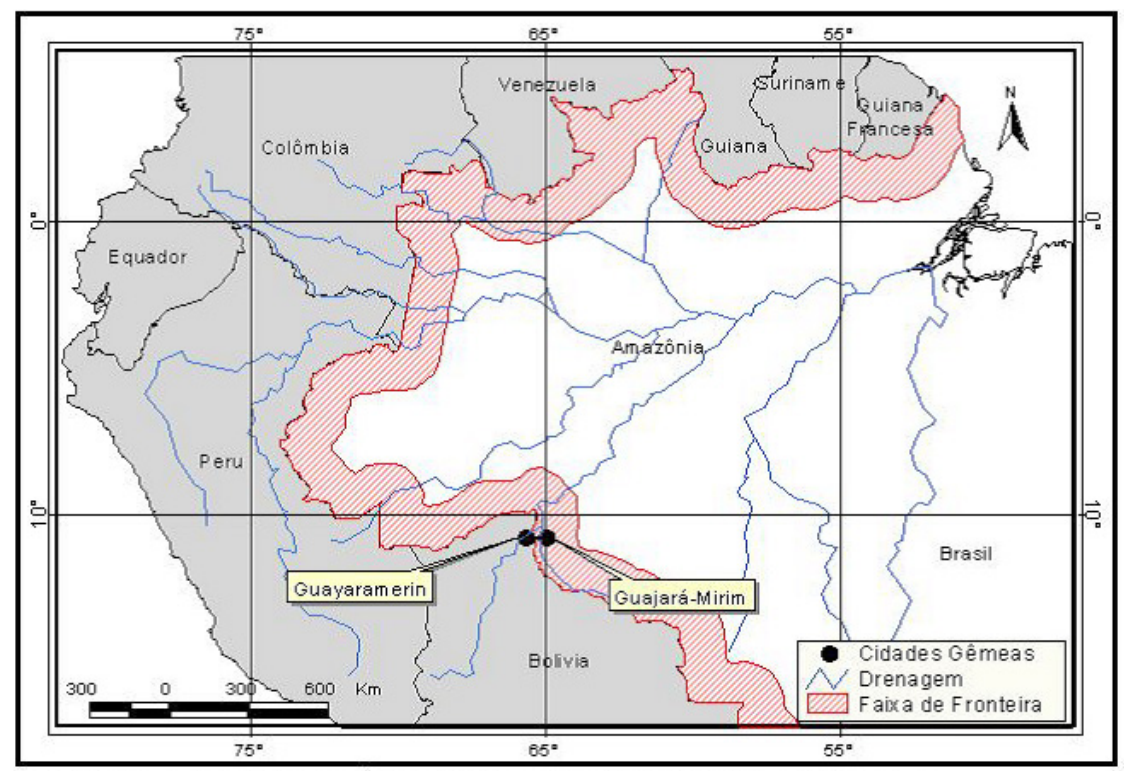

Fonte: Adaptado do gupo RETIS, disponível em http://www.ig.e.o.ufrj.br/fronteiras/mapas/zfoidgemr.jpg

Nota: Projeto cartográfico: Iranilda Moraes; Execução: Patricia Oliveira, 1/4/2008

Guajará-Mirim, o segundo município mais antigo do Estado de Rondônia, passou por todas as etapas de colonização que marcaram a ocupação do estado. Até o início do século XIX, "Guajará-Mirim era apenas uma indicação geográfica para designar o ponto brasileiro à povoação boliviana de Guayaramerin" (Vítor Hugo - Os Desbravadores). Naquela época, a povoação era conhecida como Esperidião Marques. Em 17 de 
novembro de 1903, com a assinatura do Tratado de Petrópolis entre o governo brasileiro e o governo boliviano, o Brasil se comprometia a construir uma estrada de ferro para escoamento dos produtos bolivianos, ligando o porto de Santo Antônio do Rio Madeira em Porto Velho, ao porto de Guajará-Mirim, no rio Mamoré. Os direitos sobre tarifas seriam recíprocos e a cidade de Guajará-Mirim foi se tornando conhecida no país e ganhou repercussão no exterior. O município foi oficialmente instalado em 10 de abril de 1929.

Já a cidade boliviana Guayaramerín faz parte do departamento do Beni. O território boliviano é subdividido em nove departamentos, a saber: Beni, Chuquisaca, Cochabamba, La Paz, Oruro, Pando, Potosi, Tarija e Santa Cruz, as entidades subnacionais maiores do país. Em 4 de abril de 2010, receberam autonomia reconhecida pela Constituição boliviana, contemplando os níveis executivo e legislativo, porém não judicial. Assim, o departamento tem sob sua jurisdição e responsabilidade distritos, cidades e povoados. A cidade de Guayaramerín, que em espanhol é "cachuela chica", foi fundada pelos pioneiros da borracha no ano de 1892. No período de 1905 a 1915 foi chamada de Puerto Sucre e posteriormente recebeu o nome atual. As cidades de Guayaramerin, Riberalta e Cachuela Esperanza, possuem mais de um século de existência e se desenvolveram com a produção da borracha e castanha. Os primeiros habitantes dessas cidades migraram do interior da Bolívia para trabalharem nos seringais próximos a fronteira. Naquela época tinham esperança de que a ferrovia Madeira-Mamoré cruzasse o rio Mamoré para escoar a borracha produzida naquele país. No entanto, o projeto ferroviário de ligação entre os dois países não foi concretizado, e a ferrovia permaneceu apenas em solo brasileiro.

Contudo, apesar do compromisso diplomático assumido no passado não ter sido concretizado, as duas cidades se desenvolveram e possuem atualmente uma relação amistosa. Destacamos que a população de Guajará-Mirim é formada por muitos descendentes de famílias bolivianas. Essa realidade está interligada ao processo migratório que sempre esteve presente na fronteira das respectivas cidades, porém com fluxos menores ou maiores. Temos ainda o fluxo de migração pendular: os profissionais 
liberais, comerciantes e estudantes que circulam diariamente pela fronteira. Nesse sentido, as relações políticas, sociais, comerciais, educacionais e culturais que marcam o processo de interação da fronteira passam a ganhar mais atenção.

Compreendemos, pelo processo histórico de desenvolvimento das duas cidades, que a fronteira não teve o peso do limite, pelo contrário, a interação das populações fronteiriças sempre ocorreu, formal ou informalmente, no eixo Guaporé-Mamoré. E, ainda, Becker (2009) destaca o importante papel que o rio Guaporé assume dentro de um esquema de integração da América Latina através da interconexão fluvial das bacias do Amazonas e do Prata, por via dos rios Madeira, Mamoré, Guaporé, Paraguai e Paraná.

Assim, é nesse contexto de inter-relações das populações vizinhas da fronteira Mamoré que o espaço escolar tornou-se nosso objeto de estudo, tendo em vista a quantidade significativa de alunos brasileiros e bolivianos que cruzam a fronteira diariamente para estudar. Dentre os motivos apontados por esses alunos, destaca-se a qualidade do ensino ofertado no país vizinho, porém essa questão não será analisada aqui. Como já apontado, nosso objetivo foi o de conhecermos o mundo vivido da escola boliviana. Assim sendo, nos preocupamos em conhecermos o sistema de ensino boliviano para posteriormente poder refletir e analisar as representações da escola boliviana.

\section{Qual é a função da escola na sociedade atual?}

O ser humano, diferente dos outros animais, precisa ser educado. Necessita do outro ser semelhante e mais desenvolvido para sobreviver. Desde o nosso nascimento somos submetidos a um processo intensivo de aprendizagem que é apenas encerrado quando morremos. Inicialmente, as aprendizagens que vivenciamos são constituídas em nosso núcleo familiar e nas relações estabelecidas em cada tempo e lugar; o indivíduo recebe desde o seu nascimento informações que vão modelando seu comportamento para o tipo de sociedade à qual pertence. Portanto, a família, 
por meio de um processo informal, é responsável pelas nossas primeiras relações, pelas nossas primeiras aprendizagens e pela aquisição dos conhecimentos, normas e valores da cultura onde estamos inseridos. $\mathrm{O}$ mundo da vida cotidiana apresenta-se como uma realidade interpretada pelos homens e subjetivamente dotada de sentido para eles, na medida em que forma um mundo coerente. Para Berger e Luckmamm (2012) "É um mundo que se origina no pensamento e na ação dos homens comuns, sendo afirmado como real para eles".

Com o tempo, passamos a fazer parte de outros grupos e de outras relações. Assim, as aprendizagens conquistadas nas relações familiares são os nossos primeiros parâmetros. É a partir delas que mediamos a nossa convivência com o outro, nos reconstruímos a cada nova experiência e fazemos nossas escolhas. "Até aqui o espaço educacional não é escolar. Ele é lugar da vida e do trabalho, a casa, o templo, a oficina, o barco, o mato, o quintal. Espaço que apenas reúne pessoas e tipos de atividade e onde o viver o fazer faz o saber”. (BRANDÃO, 1989, p.32).

A escola institucionalizada, espaço da educação formal, surgiu no sec. XVI, em um lento processo para responder à necessidade de separar a criança do adulto, exercendo funções que antes eram apenas da família, como cuidar e educar. Ao longo da história da humanidade, a escola passou a exercer, e até hoje exerce, uma forte influência na educação de crianças e jovens por todo o mundo. O tipo de influência que a escola exerce hoje na formação do indivíduo é objeto de investigação para estudiosos em diferentes áreas de pesquisa, mas essa questão também não é o foco deste artigo. Apenas queremos destacar a importância da função social da escola na sociedade atual. Uma função social que pode ser modeladora, opressora e excludente ou uma função social que pode ser de resistência, libertadora, aberta à realidade que a cerca e promotora de uma maior autonomia de seus agentes. Nesse sentido, ressaltamos que nenhuma prática educativa é neutra, descomprometida e apolítica.

A diretividade da prática educativa que a faz transbordar sempre de si mesma e perseguir um certo fim, um sonho, uma utopia, não permite 
sua neutralidade. A impossibilidade de ser neutra não tem nada que ver com a arbritária imposição que faz o educador autoritário a seus educandos de suas opções. (FREIRE, p.37).

Portanto, quando pensamos o espaço escolar, pensamos na consciência que seus agentes têm do papel que desenvolvem nesse espaço, em especial, os professores, porque estão diretamente em contato com os alunos e a eles cabe a imperiosa necessidade de optar, de decidir, de escolher ou romper com modelos autoritários e alienantes.

\subsection{O sistema de ensino boliviano}

De acordo com a Constituição da Bolívia (2008), é garantido a toda pessoa receber educação em todos os níveis escolares de maneira universal, produtiva, gratuita, integral e intercultural, sem discriminação. O sistema educacional boliviano está organizado, assim como o sistema brasileiro, por níveis, etapas e modalidades. Essa organização tem como base o desenvolvimento biopsicossocial dos alunos e as características de cada região. É regido pela Constituição Boliviana (2008) e pela a Lei de la Educación Avelino Siñani - Elizardo Pérez No 0.70. Segundo a referida lei, em seu Artículo 8, a estrutura da educação na Bolívia compreende os: a) Subsistema de Educação Regular; b) Subsistema de Educação Alternativa e Especial; c) Subsistema de Educação Superior de Formação Professional. O subsistema de Educação Regular é uma educação sistemática, normativa, obrigatória e processual, e contempla crianças, adolescentes e jovens. Ele possui as seguintes etapas: A Educación Inicial en Familia Comunitaria acontece em duas etapas com duração de cinco anos. Constitui-se como base fundamental para a formação integral das crianças, com a finalidade de reconhecer e fortalecer a família e a comunidade.

A Primeira Etapa, Educación Inicial en Familia Comunitaria no escolarizada, conforme a lei 070, tem duração de três anos e é a fase da educação de responsabilidade compartilhada entre a família, comunidade e o Estado. Tem como objetivo recuperar, fortalecer e promover a identidade cultural do entorno das crianças, com apoio da família. Prevenir e promover a 
saúde e a boa nutrição para o desenvolvimento psicomotor, sócio-afetivo, espiritual e cognitivo da criança. A Segunda Etapa, nomeada de Educación Inicial en Familia Comunitaria Escolarizada, tem objetivos semelhantes à primeira, acrescendo como finalidades: o desenvolvimento das capacidades e habilidades cognitivas e artísticas que favoreçam a autonomia da criança, a cooperação e tomada de decisões no processo de construção do pensamento para início do processo da aprendizagem sistemática, no nível seguinte, e possui duração de dois anos.

A Educación Primaria Comunitaria Vocacional, que compreende uma etapa da formação básica, possui caráter intracultural, intercultural e plurilíngue. Não só tem princípio formativo qualitativo, como também na formação em relação e afinidades com os saberes, as ciências, as culturas, a natureza e o trabalho de criação, que irão orientar sua vocação, e tem duração de seis anos, conforme texto da lei 070. A Educación Secundária Comunitaria Productiva, com tempo de duração de seis anos, propõe uma educação humana que valorize e desenvolva os saberes e os conhecimentos das diversas culturas em um diálogo intercultural com o conhecimento universal, incorporando a formação histórica, cívica e comunitária. Assim, os processos intracultural, intercultural e plurilíngue vivenciados pelos alunos constituem a ponte fortalecedora da formação recebida na educação. Na Educación Secundária destaca-se também o Técnico Médio, nível em que o aluno é habilitado para dar continuidade na sua formação no nível superior e, paralelamente, possibilitar a sua inserção no mercado de trabalho. Promove a formação técnica humanística com habilitações nas áreas da: agropecuária, indústria, comércio, costura, turismo e assistência social, entre outras oferecidas pela escola.

Por sua vez, a Educación Escolarizada para la Población en Desventaja Social oportuniza a educação integral escolarizada com atenção a meninos e meninas, crianças, adolescentes, jovens trabalhadores desprotegidos e em desvantagem social. Acontece por meio de programas especiais abertos às famílias com serviços integrais de saúde, alimentação, educação, reinserção escolar e sócio laboral entre outros. A Educación Alternativa e Especial, conforme Articulo 17 da Lei 070, pretende garantir às pessoas com 
necessidades especiais uma educação oportuna, relevante e abrangente, sobre a igualdade de oportunidades e equalização das condições, através do desenvolvimento, políticas, planos, programas e projetos de educação inclusiva e exercer seus direitos. A Educação especial é estruturada em três áreas e tem como público alvo pessoas com incapacidade, pessoas com dificuldades de aprendizagem e pessoas com talento extraordinário. Já o Ensino Alternativo compreende as ações educativas destinadas a jovens e adultos que querem continuar seus estudos de acordo com suas necessidades e expectativas de vida e de seu entorno social, por meio de processos educativos sistemáticos e integrais, com o mesmo nível de qualidade e equiparação de condições do subsistema regular. Tem sua atenção voltada para a Educação de Jovens e Adultos, maiores de quinze anos, oferecendo uma educação sistemática de forma gradual. A seguir, apresentamos um organograma simplificado do sistema regular educacional boliviano.

Organograma 1 - Níveis de ensino do sistema boliviano

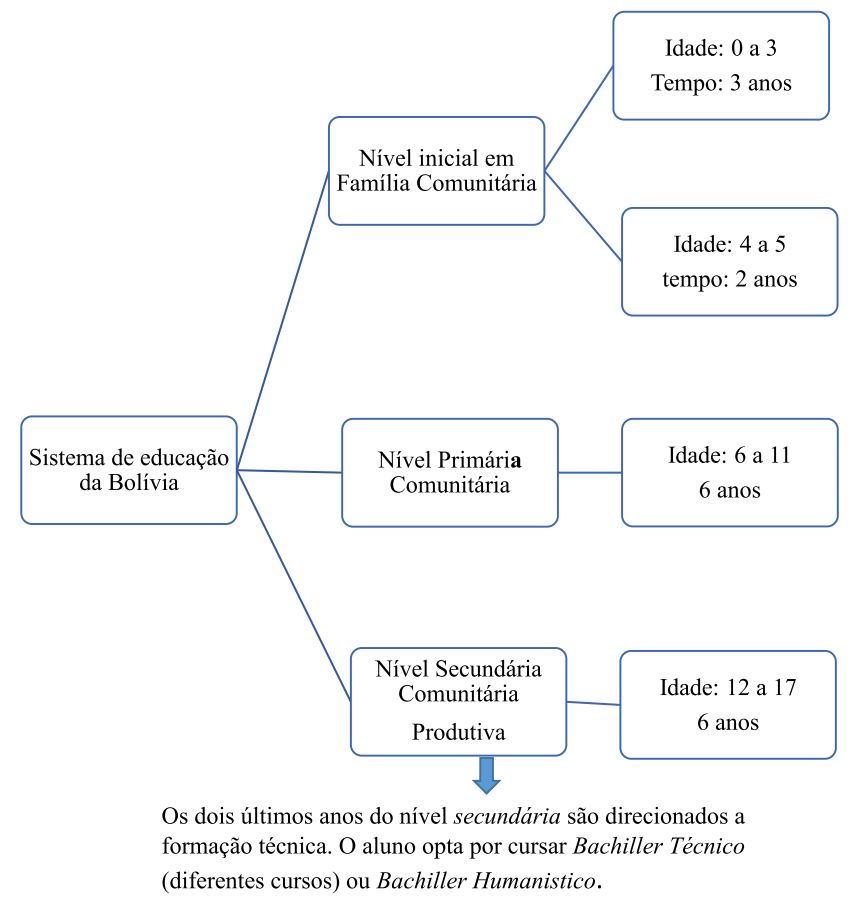

Fonte: Organizado pela autora, (2018) 


\section{$4 \mathrm{O}$ desenho como representação do mundo vivido na escola}

O ser humano está imerso em um mundo cultural e social transmitido pelas experiências diárias de comunicação, da memória coletiva e das instituições. A representação social está na base dos nossos saberes. É constituída pela conexão de processos pessoais, interpessoais e interculturais.

A representação [...] nos fornece a chave para entender a relação que amarra o conhecimento a pessoa, a comunidade e o mundo da vida.É por meio da representação que podemos compreender tanto a diversidade como a expressividade de todos os sistemas de conhecimento. (JOVCHELOVITCH,2008, p.21).

A Representação Social tem sua origem nos estudos sociológicos de Durkheim e nos estudos antropológicos de Lévi-Bruhl. Conforme Moscovici, "Nessas duas ciências [a sociologia e a antropologia] ela serviu de elemento decisivo para elaboração de uma teoria da religião, da magia e do pensamento mítico"(2012, p. 8). Esse autor influenciou ainda a teoria da linguagem de Saussure, a teoria das representações infantis de Piaget e o desenvolvimento cultural de Vygotsky. Destaque-se que estes dois últimos pensadores (Piaget e Vygostsky) tiveram fundamental importância nos desdobramentos do campo de estudos da Educação. No entanto, ainda há uma complexa discussão sobre como as Representações Sociais são geradas. Para psicólogos e sociólogos, não existe divisão entre o mundo individual e o mundo social. No mundo individual, os comportamentos e as percepções são compreendidos como processos íntimos, às vezes de natureza fisiológica, e no mundo social tudo é explicado em função de interações, trocas, estruturas, relação de poder ou outro tipo de relação coletiva.

Entendemos que as representações sociais emergem como resultado da prática social orientada para a compreensão de mundo e para a comunicação. São ainda, segundo Spink (2012), formas de conhecimento com uma estrutura cognitivo-afetiva, não sendo reduzidas apenas aos aspectos cognitivos. As representações sociais devem, 
portanto, ser estudadas articulando-se "[...] elementos afetivos, mentais, sociais, integrando a cognição, a linguagem e a comunicação às relações sociais que afetam as representações sociais e a realidade material, social e ideativa sobre a qual elas intervêm”. (JODELET apud SPINK, 2012, p. 98).

Em nosso estudo, buscamos dar sentido às representações construídas pelos alunos do ensino médio de uma escola boliviana localizada na cidade de Guayaramerín, no departamento do Beni, na Bolívia. Para realizar o processo interpretativo do material produzido, foi necessário conhecermos o sistema educacional boliviano, sua estrutura curricular e a Ley de La Educacón Avelino Siña Elizardo Perez no 070, que normatiza o sistema de ensino da Bolívia.

Para o processo de construção da representação da escola, optamos por seguir a metodologia dos Mapas Mentais, instrumentos valorosos para conhecermos e analisarmos as experiências e as relações que as pessoas têm com um determinado espaço. Tais Mapas são aqui compreendidos como enunciados que apresentam construções sígnicas, os quais estão inseridos em contextos sociais, espaciais e históricos coletivos, apresentando particularidades e singularidades. A imagem é um elemento de estudo, transmite informações sobre um determinado espaço e vai além, dependendo da metodologia, representa o espaço físico ou espaço vivido subjetivo.

Mapas são concebidos não como produtos, mas como processos socioculturais que são capazes de desencadear outros mapeamentos, maneiras de ver e representações do mudo físico, social e imaginário [...] está inserido num processo cultural mais abrangente e complexo, provocando ações ou estimulando outros mapeamentos. (COSGROVE apud KOZEL, 2009, p. 119).

Nesse sentido, os mapas mentais são enunciados que apresentam uma interação verbal intensa, são construções que têm como base a inter-relação do indivíduo com o outro. Portanto, são de fundamental importância como 
ferramenta na construção de diagnóstico relacionado a situações que envolvem a educação, além de serem instrumentos catalisadores da manifestação do desenvolvimento cognitivo, social e cultural dos alunos.

Conforme a metodologia desenvolvida por Salete Kozel (2009), os mapas mentais produzidos no processo de pesquisa são analisados pelos seguintes aspectos:

1- interpretação quanto à forma dos elementos na imagem: observam-se as formas que aparecem nas imagens. Ícones diversos, letras, mapas, linhas, figuras geométricas e outros;

2- Interpretação quanto à distribuição dos elementos na imagem: observa-se como as formas estão dispostas na folha, ou seja, horizontalmente, de forma isolada, dispersa, em quadros e outros;

3 - Interpretação quanto à especificidade dos ícones a serem observados: elementos da paisagem natural, elementos da paisagem construída, elementos móveis, elementos humanos;

4 - Apresentação de outros aspectos particulares: nessa fase se estabelece a codificação das mensagens veiculadas inicialmente pelo olhar do pesquisador e, depois, com a complementação do autor.

4.1 Os mapas mentais da escola boliviana: produção e análise

Para aplicarmos os mapas mentais na escola boliviana, foi necessário realizar contato com o diretor da escola, apresentar nossa proposta de trabalho e definir dia, horário e local para aplicação. Optamos por trabalhar com alunos da Educación Secundária, com idade entre 12 e 17 anos. De cada turma foram escolhidos, aleatoriamente, entre 3 a 4 alunos de cada turma, totalizando 20 alunos, entre homens e mulheres.

Organizamos os alunos em uma sala ampla com mesas, nos apresentamos, explicamos o objetivo do nosso trabalho, e todos aceitaram participar. O processo de aplicação dos mapas mentais ocorreu por um período de 1hora e 30 minutos. Instigamos o processo de produção, solicitando que representassem a escola a partir do seguinte questionamento: $\mathbf{O}$ que é a escola para você? Ao final do processo de construção, os voluntários foram 
convidados a falarem um pouco sobre suas representações. Os comentários contribuíram para a análise final dos mapas mentais.

\subsubsection{Os mapas mentais da escola boliviana}

Optamos por trazer para este artigo duas produções para nossa análise. Os mapas mentais serão apresentados a seguir:

Mapa Mental 1 - aluno de 16 anos

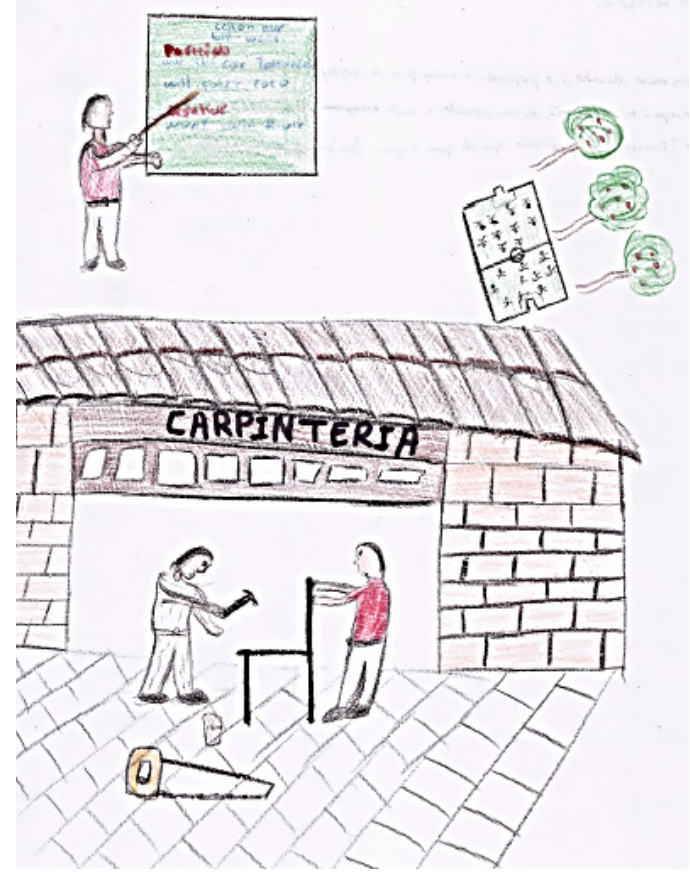

Fonte: Coleta de dados. Projeto Geopedagogia, IFRO/CNPq, ciclo 2014-2015

O Mapa Mental 1 foi feito por um aluno boliviano de 16 anos da Educación Secundária. Nele estão presentes elementos humanos, elementos da natureza e elementos construídos pelo homem. Percebemos que o aluno organizou a representação da escola em três quadrantes. $\mathrm{O}$ primeiro, na parte superior, do lado esquerdo, apresenta um professor expondo um conteúdo na lousa; no segundo quadrante, lado direito, foi representada a quadra da escola bem arborizada, com um grupo de alunos 
jogando. E o terceiro quadrante, bem maior que os anteriores, representa o espaço das aulas de carpintaria. Podemos perceber que as representações dos espaços seguem tamanhos diferentes e, em nossa interpretação, consideramos que o tamanho do desenho deixa emergir a importância desses espaços para o aluno. Assim, pelo desenho, concluímos que o espaço da oficina de carpintaria tem maior importância para esse aluno. E, ainda, a sala da carpintaria é o único espaço onde ele, aluno, está representado. Os outros espaços desenhados apresentam uma perspectiva de observação e não de participação. Nesse sentido, concluímos que a formação técnica-profissional que a escola oferece ganha maior atenção do aluno. Fato que foi comprovado quando fizemos a entrevista sobre o desenho: o aluno afirmou que a marcenaria é a profissão que ele quer seguir.

$\mathrm{O}$ sistema de ensino boliviano inclui no currículo da Educación Secundária a formação técnica. Para a maioria dos alunos bolivianos, a formação técnica é uma das poucas chances que alunos das classes menos favorecidas têm para ingressar no mercado de trabalho. A universidade é um sonho distante. Há poucas vagas públicas, de acordo com a lista de universidades públicas e privadas disponibilizada no site do Estado Plurinacional Boliviano ${ }^{3}$. A Bolívia possui 16 (dezesseis) universidades públicas e 34 (trinta e quatro) privadas. A entrada na Universidade pública boliviana é feita por um processo seletivo, baseado em uma prova de conhecimentos. Situação que contribui para os alunos menos preparados não conseguirem aprovação e, consequentemente, a vaga na universidade pública. Há ainda a distância geográfica dos centros universitários, como, por exemplo, Santa Cruz, Cochabamba e La Paz, onde está concentrado uma boa parte dos cursos de medicina e odontologia. Nessas cidades, o fluxo de estudantes é intenso, e elas possuem um custo de vida mais alto, uma realidade que fica bem distante do poder aquisitivo dos filhos de campesinos, por exemplo.

Portanto, consideramos que, quando o aluno destaca a representação do taller de carpinteria, ele destaca a possibilidade de uma formação que

${ }^{3}$ Disponibilizado em: http: //www.bolivia.gob.bo/ndex4.html, Consultado em 20/02/2018 
pode garantir sua inserção no mundo do trabalho, gerando uma condição de renda e uma melhor qualidade de vida para ele e a família.

Mapa Mental 2 - aluna de 17 anos

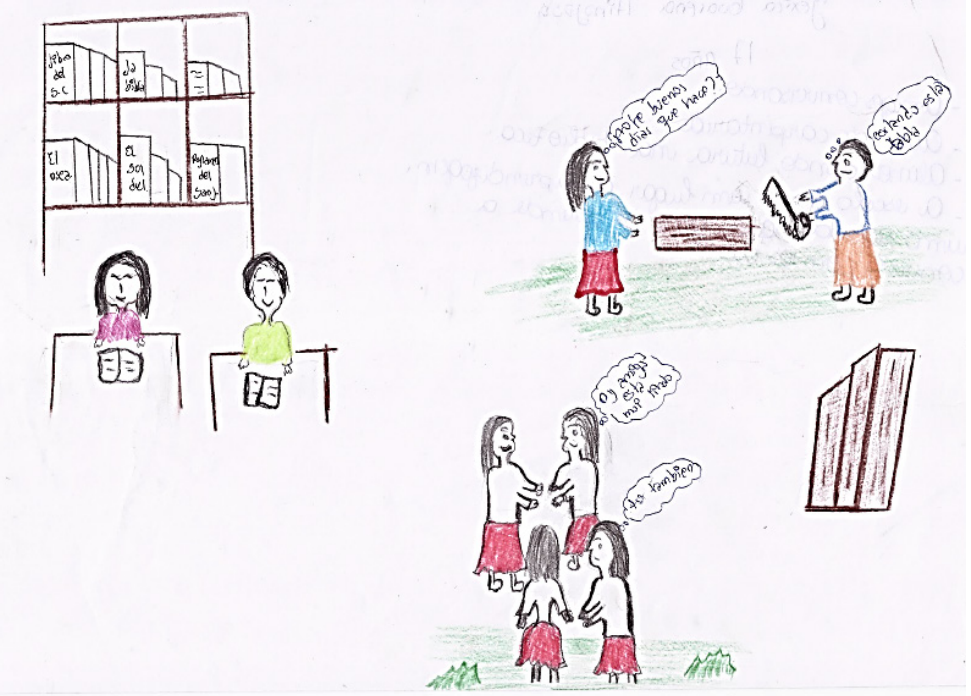

Fonte: Coleta de dados. Projeto Geopedagogia, IFRO/CNPq, ciclo 2014-2015

O Mapa Mental 2 foi construído por uma aluna da etapa final da Educación Secundária. O desenho foi organizado em quadrantes, e os espaços das cenas representadas têm tamanhos similares. Foram representadas figuras humanas, elementos construídos pelo homem, elementos naturais e há também palavras em espanhol representando o diálogo entre uma aluna e um professor e o diálogo entre um grupo de alunas.

No primeiro quadrante, parte superior lado esquerdo, foi representado o espaço de uma sala que serve como biblioteca. Na escola visitada para pesquisa, esse espaço é amplo, porém há poucos livros para consulta e eles ficam disponibilizados em uma estante pequena no fundo da sala. Porém, é um ambiente arejado, amplo, iluminado com mesas e cadeiras.

O segundo quadrante, lado direito superior, o espaço da formação técnica, o Taller de Carpinteria também é representado pela aluna. $\mathrm{Na}$ cena representada temos a aluna e o professor; no diálogo construído ela cumprimenta o professor e pergunta sobre o seu processo de produção. 
Vale destacar, nessa cena, o respeito presente no diálogo construído. $\mathrm{Ou}$ seja, a aluna educadamente cumprimenta o professor antes de questioná-lo e então ele responde. Vale salientar que, nas observações realizadas nas instituições educacionais bolivianas, em espaços familiares e comerciais, o respeito e a educação com as pessoas mais velhas é um aspecto do processo de formação que chama atenção. $\mathrm{O}$ respeito ao maestro (professor) pode ser igualado ao respeito que eles têm aos familiares mais velhos: papá, mamá y aboelos.

Destacamos, também, o interesse da aluna no estudo e na formação técnica, cenas do cotidiano que representam a importância dessas práticas na vida dela. A valorização pelo estudo e pela formação técnica ganha mais sentido quando conhecemos um pouco mais da cultura boliviana. Conforme Silva (2005), é no imaginário da cultura milenar Inca que os bolivianos procuram elementos que norteiam a vida presente. Destacam-se em especial três valores de conduta: ama keilla ( não sejas mentiroso), ama suya ( não sejas preguiçoso) e ama lula ( não sejas ladrão). Então, nesse processo, o ethos "trabalho" está sendo valorizado, porque não sobra espaço para preguiça e, pelo trabalho, é possível uma ascensão econômica.

Entretanto, para alguns bolivianos essa condição de trabalho nem sempre é conquistada dentro do próprio país. Assim, o processo migratório torna-se opção para muitas famílias, e o Brasil é uma das rotas principais. Em Guajará-Mirim, por exemplo, o imigrante boliviano ocupa as vagas de trabalho na construção civil, fabricação de móveis, produção de hortaliças, fabricação de pães, costura, serviços nas fazendas, entre outros. Mas o maior fluxo migratório é direcionado ao Estado de São Paulo, onde está concentrado um grande mercado de confecção de roupas. Famílias inteiras migraram para lá; algumas conseguiram se estabilizar, outras tiveram que retornar ao país de origem, tendo em vista as condições de trabalho e moradia, que muitas vezes eram desumanas.

Portanto, para o aluno boliviano que vem de uma família de baixa renda, ou até mesmo uma renda mediana, ter uma formação técnica na área de corte costura, por exemplo, é ter a possibilidade de uma mobilidade econômica, por um trabalho realizado fora do país de origem. E se a migração 
for bem sucedida, o resultado do trabalho poderá mudar a vida das pessoas que ficaram, em especial dos jovens em idade escolar que, com apoio financeiro, podem seguir os estudos na Universidade particular, em um curso de Medicina, por exemplo.

\section{Tecendo algumas considerações finais}

Quando propomos a representação da escola por alunos da Educación Secundária, criamos a possibilidade de conhecer o mundo escolar vivido por esses alunos. Abrimos espaço para a experiência empírica, dotada de subjetividade e de sentimento.

Para o ser humano, sua consciência e cultura são únicos em sua identidade, todavia, são produtos incorporados de outras consciências, outras culturas, mediadas pela comunicação que se instala no centro das relações. “ [...] os discursos ao serem incorporados se constituem em signos que se transformam em enunciados ou representações nas diferentes formas de linguagem”. (KOZEL, 2009, p.3). Os mapas mentais refletem, portanto, as representações dos indivíduos em relação ao espaço geográfico e ao espaço vivido, cujos signos são construções sociais.

O projeto nos possibilitou ir além dos muros, das paredes, dos limites da sala de aula. Para a leitura dos Mapas Mentais, tivemos que sair da nossa zona de conforto e conhecer a organização do sistema de ensino boliviano e o processo de formação dentro das escolas. E, nesse novo contexto, com uma realidade social, cultural e educacional tão diferente do contexto das escolas brasileiras, percebemos a necessidade de redimensionar o nosso olhar para poder interpretar os desenhos construídos por esses jovens.

Com as representações construídas, podemos apontar que, dos 20 alunos participantes, conforme descrito anteriormente, apenas cinco representaram o espaço da formação técnica, enquanto os outros mapas representaram o espaço de lazer, a quadra de jogos e danças, o espaço da sala de aula e a fachada da escola.

Nossa opção em analisar os Mapas Mentais que representam o espaço de formação técnica tem como base o nosso conhecimento do 
universo social boliviano, em especial, os conflitos vivenciados pelas diferentes classes sociais que compõem a sociedade boliviana. Nesse caminho interpretativo, foi necessário conhecer aspectos importantes da formação do povo boliviano.

A pluralidade étnica e cultural boliviana é uma realidade complexa e desafiadora para quem não é boliviano. $\mathrm{Na}$ Bolívia, a figura do colonizador - representado pelo homem branco que colonizou e impôs sua cultura, seu modo de produção, seus valores religiosos, seu modo de vida entre outras coisas - é vista como um ícone de opressão pela maioria da população. Uma população indígena formada por diferentes grupos étnicos. E, conforme Silva (2005), uma população que não aceita ficar em uma posição de inferioridade na escala da estratificação social.

Em 1977, o Estado Plurinacional Boliviano reconheceu o Quéchua e o Aymará como línguas oficiais, além da língua Castellãna. Foi um avanço a favor do plurilinguismo boliviano, porém, essa ação política não garantiu que o preconceito aos grupos falantes dessas línguas (maioria indígena) fosse eliminado. Há na Bolívia uma divisão étnica muito forte; de um lado temos os descendentes espanhóis, uma minoria branca, e do outro, temos a maioria indígena, campesina, mais pobre. Entre esses dois grupos há os mestiços, “[...] denominados de cholos, termo que significa o resultado da miscigenação entre espanhóis e indígenas. Estes, por sua vez, procuram ascender socialmente investindo na educação de seus filhos, para que estes deixem de ser identificados como índios”. (SILVA, 2005, p.12).

A escola, nesse contexto, torna-se a porta para essa possível ascensão, na medida em que oportuniza a formação técnica em diferentes áreas. Ter uma formação técnica pode ser a única condição para jovens trabalhadores campesinos que sonham em morar na cidade, ter um emprego remunerado, uma melhor condição de trabalho e de vida. Assim, com essa nova condição social, é possível projetar um futuro mais ousado, uma formação superior, por exemplo. "O trabalho permanece como referência dominante não somente economicamente, mas também psicologicamente, culturalmente e simbolicamente, fato que se comprova pelas reações daqueles que não o tem.” (CASTEL,1998, p.37). 
Os conflitos culturais, políticos e sociais da Bolívia e a busca pelo trabalho, um emprego com melhor salário, são fatores que contribuem para que muitos bolivianos migrem para outros países. $\mathrm{O}$ território Boliviano faz fronteira com a Argentina e o Paraguai ao sul, com o Chile e Peru ao oeste, e com o Brasil ao norte e ao leste, sendo esta a maior fronteira. Essa condição geográfica contribui para o constante deslocamento de jovens, homens, mulheres e famílias inteiras bolivianas para outros países. O Brasil, na última década, recebeu bolivianos que deixaram seu país de origem para trabalharem nas fábricas de confecção na cidade de São Paulo. Mas viver a aventura da imigração pode ser muito arriscado e gerar muito sofrimento, tendo em vista que estudos realizados nos últimos anos, sobre a imigração boliviana em São Paulo, denunciaram várias situações desumanas que muitos imigrantes vivem, como por exemplo: moradias precárias, carga horária de trabalho exaustiva, salários baixos, enfim, "um sistema de escravidão", conforme reportagem do G1 São Paulo ${ }^{4}$.

Contudo, há histórias de imigrantes que conseguiram trabalhar de forma digna, recebendo um salário mínimo e horas extras. Assim, conseguiram juntar dinheiro e voltar para Bolívia e investir na formação dos filhos ou iniciar um pequeno negócio. Histórias de migrações de sucesso são contadas e recontadas, e ajudam a manter viva a vontade de migrar para grandes metrópoles, como a cidade de São Paulo.

\section{Referências}

BAENINGER, Rosana. O Brasil na rota das migrações latino-americanas. In:

(Org.). Imigração boliviana no Brasil. Campinas: Núcleo de Estudos de População-Nepo/ Unicamp; Fapesp; CNPq; Unfpa, 2012.

BECKER, Bertha. Amazônia. Geopolítica na virada do III milênio. Rio de Janeiro: Garamond, 2009.

BERGER, Peter L.; LUCKMANN, Thomas. A construção social da realidade. 34.ed. Trad. Floriano de Souza Fernandes. Petrópolis: Vozes, 2012.

4 Fiscais flagram bolivianos em situação semelhante à escravidão. Reportagem publicada em http://g1.globo.com/sao-paulo/noticia/2014/05/fiscais-flagram-bolivianos-em-situacao-semelhante-escravidao-em-sp.html dia 16/05/2014, consultada em 10/10/2018. 
BOLIVIA. Ley de la Educación Avelino Siñanis Elizardo Péres no 070, 2010.

BRANDÃO, Carlos Rodrigues. Pesquisa participante. São Paulo: Brasiliense, 1981

CASTEL, Robert. As transformações da questão social. In: BÓGUS, L.; YAZBEK. M.C.; WANDERLEY, M. (Orgs.). Desigualdade e a questão social em São Paulo: EDUC, 1997.

CAMACHO, Gaby Cuellar. História del beni para estudiantes. Guayaramerin/BOL: Impressiones La maravilla, 2010.

FRANCO, Luiz A. de C. A escola do trabalho e o trabalho da escola. 3.ed. São Paulo: Cortez-Autores Associados, 1991.

FREIRE, Paulo. Pedagogia do oprimido. 17. ed. Rio de Janeiro: Paz e Terra, 1987.

FREIRE, Paulo. A importância do ato de ler em três artigos que se complementam. 23. ed. Coleção polêmicas do nosso tempo. São Paulo: Cortez, 1989.

GUARESCHI, Pedrinho; JOVCHELOVITCH, Sandra. (Orgs). Textos em representações sociais. 9. ed. Petrópolis: Vozes, 2007.

GALVÃO, Wilson; KOZEL, Salete. Representação e ensino de geografia: contribuições teórico-metodológicas. Ateliê Geográfico, Goiânia-Go, v.2, n.5, dez/2008, p.33-48. Disponível em: http://www.revistas.ufg.br/index.php/article/view/5333. Acesso em: 11 abril 2011.

HUGO, Vitor. Desbravadores. Amazonas: Missão Salesiana de Humaitá, 1959.

JOVCHELOVITCH, Sandra. Narratyve, memory and social representations: a conversation between history and social psychology. In: Integrative Psychological and Behavioral Science, v.46, n.4, p. 440-456, 2012.

KOZEL, Salete. As linguagens do cotidiano como representações: uma proposta metodológica possível. Disponível em: http://egal2009.easyplanners.info/area02/2088_KOZEL_ Salete.pdf. Acesso em: 11 abril 2011.

KOZEL, Salete. Representação e Ensino - Aguçando o olhar geográfico para os aspectos didático-pedagógicos. In: SERPA, Angelo. (Org.). Espaços Culturais - vivências, imaginações e representações.. Salvador: Edufba, 2008. p. 71 a 88.

MOSCOVICI, S. Psicanálise, sua imagem e seu público. Petrópolis, RJ: Vozes, 2012.

SILVA, Sidney A. da. Imigrantes no Brasil, Bolivianos: a presença da cultura Andina.

São Paulo: Companhia Editora Nacional, 2005.

SPINK, M, J. Desvendando as teorias implícitas: uma metodologia de análise das representações sociais. In: GUARESCHI, P.; JOVCHELOVITCH, S. (Orgs.). Textos em representações sociais. 13. ed. Petrópolis: Vozes, 2012. 


\title{
2. A ESCOLA NO HAITI EM MAPAS MENTAIS DE CRIANÇAS
}

\author{
Rosa Martins Costa Pereira' \\ Patrícia Pereira da Silva² \\ Samuel Dorvilus ${ }^{3}$ \\ Budiene Martins da Silva ${ }^{4}$ \\ Cledenice Blackman ${ }^{5}$
}

\section{Introdução}

Os direitos culturais não dizem respeito apenas à proteção de autoria, mas ao direito de participar livremente da vida cultural da comunidade, bem como de fruir as artes, contribuir e ser beneficiado pelos processos e resultados da ciência. Educar é um ato que acontece no convívio social.

1 Pedagoga, Especialista em Metodologia do Ensino Superior e em Gestão Escolar, Mestre e Doutora em Geografia. Pesquisadora do Grupo de Pesquisa em Educação, Filosofia e Tecnologias GET/IFRO onde coordena o núcleo de estudo de Educação e Migração. Técnica em Assuntos Educacionais do Instituto Federal de Rondônia - Reitoria.

Email: rosa.martins@ifro.edu.br.

2 Tecnóloga em Gestão Pública e licencianda em Letras Português e suas Respectivas Literaturas. Pesquisadora do Grupo de Pesquisa em Educação, Filosofia e Tecnologias GET/ IFRO.E-mail: patthypds@gmail.com.

3 Pedagogo pela Escola Normal dês Gonaives Saint-Pierre Claver- Artibonite. Especialista em Ensino de Língua Inglesa e Francesa pela Escola Normal dês Gonaives Saint-Pierre Claver-Artibonite. Graduado em Tecnologia de Gestão de Recursos Humanos/UNIRON e Especialista emGestão de Pessoas e Psicologia Organizacional. Pesquisador do Grupo de Pesquisa em Educação, Filosofia e Tecnologias GET/IFRO.

E-mail: dorvilussamuel@gmail.com

4 Licenciado em Letras/Inglês, Especialista em Metodologia do Ensino Superior, Graduação em andamento em Letras/Francês. Pesquisador do Grupo de Pesquisa em Educação, Filosofia e Tecnologias GET/IFRO.E-mail: buddy_martins@yahoo.com.br

5 Licenciada e Bacharela em História, Bacharela em Biblioteconomia, Mestra em História e Estudos Culturais e Doutoranda em Educação pela Universidade Estadual Paulista "Júlio de Mesquita Filho” - UNESP/Marília. Sob a orientação da Prof. a Dra. Tânia Suely Antonelli Marcelino Brabo. Bibliotecária do Instituto Federal de Educação, Ciência e Tecnologia de Rondônia - IFRO. Pesquisadora do Grupo de Pesquisa em Educação, Filosofia e Tecnologias - GET/IFRO. Email: cledenice.blackman@ifro.edu.br 
Nesse sentido, Ferreira (2011) afirma que a educação coincide com os conceitos de socialização e endoculturação, mas não se resume a eles.

Este texto apresenta um recorte dos resultados do Projeto "Geopedagogia: a escola em mapas mentais de alunos brasileiros, haitianos e bolivianos", vinculado ao Programa Institucional de Pesquisa do Instituto Federal de Educação, Ciência e Tecnologia de Rondônia (IFRO). O objetivo da pesquisa foi conhecer representações sobre a escola de alunos brasileiros, bolivianos e haitianos por meio de mapas mentais. O projeto envolveu duas formas de inserção de campo: o suporte teórico-metodológico da aplicação de mapas mentais, proposto por Kozel (UFPR), e a análise de mapas mentais de estudantes. Este estudo tem, pois, como base, a análise de cinco mapas mentais de crianças, aplicados nos arredores de Porto Príncipe, no ano de 2015.

O suporte teórico-metodológico teve como base os campos da Geografia Cultural, especialmente, os trabalhos desenvolvidos por Kozel sobre a metodologia de mapas mentais, e o campo da Psicologia Social, por meio da Teoria das Representações Sociais de Serge Moscovici. A escolha por essa metodologia de análise está ancorada no estudo de aspectos subjetivos de discursos e práticas socioespaciais, e teve como questão norteadora a pergunta “o que é a escola para você?".

A pesquisa possibilitou a experiência de cartografar o que é a escola para o aluno que expressa um modo diferente de falar ao outro, como se o desenho fosse para si mesmo. Entretanto, essa comunicação só se concretiza em um contexto da experiência em que tanto a fala quanto o outro são componentes estruturantes do pensamento. No caso das crianças haitianas, ficou evidente que essa cartografia se expressa por meio das dificuldades de acesso à escola, assim como pelas experiências diversificadas em salas de aula multisseriadas.

\section{Haiti: país de montanha}

De acordo com informações consolidadas por Grondin (1985), o Caribe, também chamado de Caraíbas, é uma região do continente americano formada pelo Mar do Caribe e composto por 27 ilhas e 4 territórios 
em terra firme, que atualmente abrigam 32 países colônia ou departamentos diferentes.

Em 1492, Cristóvão Colombo chega ao território do Haiti e toma posse dessas terras tornando o local uma colônia espanhola e a chama de Hispaniola. Desde então a ilha passa a ser fonte de exploração humana e de recursos naturais, como o ouro. Essa exploração foi feita sem nenhuma preocupação com os nativos, que eram forçados a trabalhar até a exaustão. Em um curto período de 50 anos de colonização e exploração, os autóctones foram quase totalmente dizimados (MARCPHERSON, 1963, p. 22).

Em 1697, o rei da Espanha Charles II cede ao rei da França Luís XIV a parte ocidental da ilha, como consequência da derrota militar da Espanha para a França na Guerra Europeia. Luís XIV passa a chamar a região de São Domingo. Esse período de dominação francesa fez com que a situação da ilha piorasse ainda mais.

No século XVIII, os franceses instalam no Haiti um sistema de exportação agrícola, baseado na cultura do café e cana de açúcar, que naquele período eram muito valiosos, fazendo que o Haiti fosse chamado "A Pérola da Antilhas". A crescente demanda por açúcar fez, consequentemente, que também fosse estabelecido um maior número de mão de obra escrava no país. Os colonos franceses de São Domingo rapidamente ficaram ricos à custa do trabalho da mão de obra escrava africana. Os escravos viviam em situações desumanas, forçados aos duros trabalhos de lavoura e mineração. As mulheres negras escravizadas sofriam com os maus tratos e constantes estupros e, como resultado dessa violência, nasciam os mulatos. Fato curioso é que esses mulatos, apesar de não serem brancos, sentiam-se superiores aos negros e em hipótese alguma admitiam comparações.

Em 1791, com a queda da Bastilha e o implemento da Revolução Francesa, ecoava pelo mundo o famoso lema sob as bandeiras da "liberdade, igualdade e fraternidade", mas esses ecos não chegam a San Domingo, onde os senhores das plantações, sentindo-se ameaçados, rejeitam os três princípios bases da nova ordem mundial, mantendo assim a escravidão. No entanto, os negros e mulatos começam sua própria revolução na ilha, implementando por si mesmos esses princípios. Nessa fase, surge a 
figura do famoso "mulato", que toma a frente da revolução. Toussaint, filho de escrava negra Toussaint Louverture com homem branco, criado por uma família de colonos, encabeça o movimento, declarando uma guerra violenta contra os senhores donos de plantações. Em primeiro de janeiro de 1804, Toussaint Louverture declara a independência do Haiti, após abater o regimento de Napoleão Bonaparte.

O preço pago pelo Haiti por sua independência foi grande, pois os rebeldes, ao atearem fogo em todas as plantações, destruíram não apenas o sistema econômico e comercial dos senhores, mas também toda a estrutura econômica do país, afetando diretamente a população que vivia no Haiti. Outro ponto que dificultou que o Haiti pudesse ascender foi o isolamento político e econômico por parte dos países europeus que não aceitavam que um país colônia fosse governado por um negro. $\mathrm{O}$ golpe de misericórdia veio em 1825, ano em que o Haiti faz um acordo com a França para conseguir definitivamente sua independência. $\mathrm{O}$ acordo feito com o rei da França Charles X estabelecia que o Haiti pagasse 150 milhões de francos em ouro para reparar os danos "sofridos" pelos senhores das plantações, porém esse montante chega a ser novamente acordado em 90 milhões de francos em ouro. Uma longa e penosa dívida assumida para ganhar a liberdade. O Haiti, devastado pela exploração, começa então uma longa caminhada para o reconhecimento internacional do país como uma república independente.

O Vaticano acaba por tomar a frente nesse propósito e, em 1860, reconhece oficialmente o Haiti como uma República Católica de Negros. Em 1862, com o fim da Guerra da Secessão Americana em que ocorreu a abolição dos escravos em solo americano, os Estados Unidos da América reconhecem o Haiti como uma República independente. Mesmo com essas afirmativas internacionais, a França não reconhece o Haiti como um país independente. Apenas em 1934 o Haiti consegue liquidar a absurda dívida contraída para conseguir a liberdade.

$\mathrm{Na}$ tentativa de encontrar uma saída de recuperação para a economia do país, o Haiti propôs, através de sua elite, um projeto de reconstrução nacional. Assim, uma nova classe de poder dirigente se formou no país, 
não modificando as estruturas sociais e mantendo os trabalhadores, que eram maioria, ainda explorados e sem direito de opinar nas decisões que envolviam a política, os direitos sociais e a recuperação do país. Os governos foram se sucedendo, mas nunca permitindo a participação da classe trabalhadora no poder.

Em 1915, os americanos desembarcaram no Haiti como parte do sucesso para a estabilidade, mas na verdade deixaram ao Haiti uma herança aprisionadora, deixaram uma força armada profissional que intensificou a repressão em vez de contribuir para a libertação.

Em 1957, chega ao poder François Duvalier, que faz uso de todo o ressentimento dos negros até então para conseguir se eleger. Duvalier poderia ter feito uma verdadeira democracia, mas, ao contrário do que a população esperava, ele estabelece uma verdadeira ditadura, eliminando todos os que eram contra seu governo ou que pensavam de forma diferente. Esse período fica conhecido como a época dos "Tontons Macoutes" que significa "bichos-papões", grupo de guerrilha armada que aniquilava todos os opositores da presidência vitalícia de Duvalier. Esse grupo dava sustentação ao governo ditador de François Duvalier, chamado pelo povo do Haiti de Papa Doc (papai doutor).

Papa Doc foi o maior ditador das Américas, e sua milícia extorquia dinheiro de estrangeiros e de empresários. Durante seu reinado, mandou prender e matar profissionais da imprensa; expropriou terras para a montagem de academias para seus militares, cobrou dinheiro do povo para a construção da sua Duvalierville, dinheiro esse que desviou para suas contas particulares no Haiti e na Suíça.

Com a morte de Papa Doc em 1971, seu reinado é automaticamente passado para seu filho Jean-Claude Duvalier, o "Baby Doc" que, acostumado ao regime de opressão e violência regido pelo pai por 12 anos, dá continuidade ao governo paterno. Baby Doc é deposto em 1986, após uma revolta popular. Mesmo com a retirada do poder das mãos da família "Doc", a democracia não foi restabelecida como deveria. Sempre que surgia algum grupo nesse sentido, era disseminado. 
O Haiti, ainda mais explorado, em completa miséria, deteriorado economicamente, com a maioria da população vivendo em condições desumanas, estatisticamente entre os maiores índices de pessoas analfabetas do mundo, com uma saúde precária, em que a maioria, se não sofria de tuberculose, tinha desnutrição, passa a ser comandado pelo padre Jean Bertrand Aristides, que prega principalmente uma partilha mais justa de poder e das riquezas.

Infelizmente, Aristides não consegue realizar seu projeto de justiça econômica e social, pois, de um lado, havia os políticos acostumados com facilidades e que não querem mudar o sistema, e de outro lado, um líder carismático que não quer perder o poder. Em 1991, Jean Bertrand sofre um golpe de estado, as eleições são contestadas, e surge, então, um novo grupo armado que passa a substituir os Tontons Macoutes. Essa nova fase de governo militarizado surge principalmente pela total ausência e interferência das comunidades internacionais.

\section{A educação escolar no Haiti}

Em francês, o país é chamado de La Perle des Antilles (A Pérola das Antilhas), por conta de sua beleza natural. O ponto mais alto do país é Pic la Selle, com 2.680 metros de altitude. Tanto em área quanto em população, o Haiti é o terceiro maior país do Caribe (depois de Cuba e da República Dominicana), com 27.750 quilômetros quadrados e cerca de 12,4 milhões de habitantes, sendo que mais de um milhão deles vivem na capital, Porto Príncipe. $\mathrm{O}$ francês e o crioulo haitiano são as línguas oficiais do país.

A posição histórica e etnolinguística do Haiti é única por várias razões. Quando conquistou a independência em 1804, se tornou a primeira nação independente da América Latina e do Caribe, sendo o único país do mundo estabelecido como resultado de uma revolta de escravos bem-sucedida, e a segunda república da América. A Revolução Haitiana, feita por escravos e negros libertos, durou quase uma década; todos os primeiros líderes do governo foram antigos escravos. O país é uma das duas nações independentes do continente americano (junto com o Canadá) que designa 
o francês como língua oficial; as outras áreas de língua francesa no continente são todos departamentos ou coletividades ultramarinos da França.

3.1 O processo de escolarização e a implicação das línguas oficiais no ensino

No Haiti, o sistema educativo é administrado e controlado pelo Ministério da Educação Nacional e da Formação Profissional (MENFP). O modo de funcionamento do sistema é regido pelo Decreto-lei, datado de 8 de maio de 1989, que descreve as funções das diferentes instâncias administrativas nele definidas. A estrutura organizacional agrega um conjunto de direções centralizadas e descentralizadas que operam sob a inspetoria da Direção geral do ministério. A esta última, são subordinadas várias instâncias administrativas e técnicas centrais, como, entre outras, o Bureau de Gestão da Educação Pré-escolar (BUGEP), as Direções do Ensino Fundamental (DEF) e do Ensino Secundário (DES), a Direção da Planificação e da Cooperação Externa (DPCE).

Atualmente, parece que esforços estão sendo feitos para descentralizar mais os serviços. Para isso, mais comissões estão sendo criadas ou remanejadas pelo governo atual via Plano Operacional 2010-2015, com o objetivo de melhorar e reestruturar o sistema da educação.

No Haiti, o sistema educativo abrange a Educação Pré-escolar, a Escola Fundamental, o Ensino Secundário, a Formação Profissional e o Ensino Superior. Atualmente, está sendo incorporado outro setor, dito Informal, que deve ter como responsabilidade a alfabetização e pós-alfabetização das pessoas com 16 anos de idade ou mais, que, aparentemente, não frequentaram a escola como devido. A Educação pré-escolar visa às crianças de 3 a 5 anos de idade, não é obrigatória e não é a cargo do Estado. Todavia, esforços e mobilizações estão sendo desdobrados por parte do Estado, com a ajuda de certos organismos internacionais, para a implantação do ensino público nesse nível de escolaridade. Uma das justificativas é o alto índice de mortalidade infantil no país (às vezes até $50 \%$ das crianças de 0-5 anos de idade). Estar na escola é uma maneira de garantir às crianças, 
especificamente as das famílias mais pobres, o direito de viver e crescer em boa saúde física, emocional e mental. Existe, na verdade, há cerca de uma década, uma preocupação em disponibilizar nas escolas públicas, um núcleo responsável pelo atendimento das crianças de 3 a 5 anos de idade. No entanto, até o momento a maioria das escolas ainda não oferta esse procedimento.

O ensino fundamental é organizado em três (3) ciclos que dura, no total, nove (9) anos e se dirige às crianças de 6-14 anos de idade. $\mathrm{O}$ primeiro ciclo compreende quatro (4) anos de estudos ( $1^{\circ}$ ao $4^{\circ}$ ano), o segundo e o terceiro, respectivamente, são de dois $\left(5^{\circ}\right.$ e $6^{\circ}$ ano $)$ e três $\left(7^{\circ}\right.$, $8^{\circ}$ e $9^{\circ}$ ano) anos.

Até recentemente, o aluno no seu último ano do segundo ciclo deveria passar por uma prova do Estado para entrar no terceiro ciclo. De agora em diante, os alunos do segundo ciclo são isentos dessa prova e só terão prova do Estado no final do terceiro ciclo, para poder ingressar no ensino secundário. $\mathrm{O}$ ensino secundário, por sua parte, é organizado em quatro (4) anos e é direcionado aos jovens de 15-18 anos de idade. Para obter o seu diploma de ensino secundário, o aluno, até o ano passado (2018), precisava passar primeiro o Baccalauréat I (Bacc I), no terceiro ano, prova do Estado que representava grande barreira para os alunos que almejavam terminar os estudos.

Com efeito, muitos alunos, desencorajados, deixavam a escola nesse nível ou costumavam reprovar, às vezes, durante anos, antes de conseguir passar e finalmente ingressar no último ano. No final do último ano, o aluno tem que passar o Bacc II para obter o seu Diploma de Estudo Secundário (DES) e poder então ingressar na faculdade. Todavia, a partir deste ano, os alunos são isentos do Bacc I e só terão de passar um Bacc no final do último ano.

Essa mudança entra no quadro da ideia de reestruturação e inovação do sistema de ensino nesses últimos anos, nesse caso, o ensino secundário tradicional está sendo substituído pelo Novo Secundário, isto é, de agora em diante, os quatro anos do Secundário passarão a ser chamados de Secundário I, II, III e IV. Tal medida parece visar à renovação dos currículos por 
algo mais adaptado ao tempo atual. Essa iniciativa, um pouco atrasada, mas não tarde demais, se realizada como está escrita nos papéis, seria muito benéfica para o futuro da sociedade haitiana em geral e, em particular, para os jovens que pretendam prosseguir os estudos no país ou no exterior.

Das escolas de $1^{\circ}$ e $2^{\circ}$ ciclo recenseadas no país, somente $24,66 \%$ têm acesso à eletricidade; desse número, só 9,77\% são públicas; $13,75 \%$ possuem uma biblioteca, sendo que só $9,06 \%$ são públicas. Isso mostra como a aprendizagem das crianças é bem reduzida ao que se tem de acesso informacional no âmbito dos materiais didáticos e como elas têm um acesso muito limitado aos materiais paradidáticos, à tecnologia, à informação, isto é, a um campo de conhecimentos mais diversificados, adaptados ao tempo em que a criança vive. É óbvio que aquelas crianças que moram nas zonas rurais sofrem mais ainda dessa carência, pois, mesmo nos meios urbanos, somente $22,3 \%$ das escolas no total possuem uma biblioteca.

Como, em tais condições (nas cidades o francês é mais presente), os alunos do interior vão conseguir aprender a língua francesa quando nem recursos têm para facilitar a sua alfabetização? O francês deve ser considerado puramente língua estrangeira, pois existem lugares no interior que nem eletricidade têm; as crianças não têm nenhuma relação com a língua, visto que, nesse caso, não a escutam nem mesmo na TV. Para as crianças cuja família têm TV já é alguma coisa, pois a maioria dos filmes é transmitida em francês, todos os desenhos são transmitidos em francês, então aquelas que moram nas cidades, onde têm eletricidade, podem ter certo contato com a língua francesa desde pequenos. Mas, para as crianças dos meios rurais, a escola é praticamente o primeiro lugar em que elas vão se deparar com a língua francesa e também o único lugar onde vão ter a oportunidade de aprendê-la.

Para responder a tal exigência, a escola tem que ser muito bem preparada, pois o país possui bem arraigado em seu patrimônio o francês. Dessa forma, tem que garantir o direito das crianças a adquiri-lo, pois trata-se de uma das línguas oficiais do país. Então, podemos entender com isso que o sistema nacional de educação no Haiti, além de ser muito limitado na oferta do ensino, constitui um ensino de pouca qualidade, é um sistema que 
não visa à permanência dos alunos na escola até o final do secundário e não garante uma formação adequada do conjunto dos cidadãos.

Apesar da intensidade dos desafios da educação no Haiti, acredita-se numa mudança positiva a partir do momento em que a própria sociedade reconhecer a importância e necessidade de uma educação de qualidade, fazendo parte dela e exigindo os cumprimentos legais previstos nas leis. As previsões teóricas a respeito da educação Haitiana são lineares, contudo, há uma dicotomia muito acentuada em relação à prática.

As possibilidades de melhoria no sistema educacional haitiano existem, desde que haja um investimento planejado na formação dos professores e um olhar de valorização na área e que os recursos previstos e destinados à educação sejam radicalmente fiscalizados, para que deixem de entrar pelos ralos desnorteadores de políticos descompromissados e desinteressados com o desenvolvimento da sociedade.

É admissível afirmar que investir bem na educação é, ao mesmo tempo, apostar em um futuro próspero, de pessoas bem-sucedidas e de cidadãos conscientes, capazes de cumprir com as obrigações que lhes são exigidas e com os direitos que lhe são devidos.

Os desafios da educação haitiana não são, simplesmente, exclusivos dos seus profissionais, mas de toda a sociedade.

A educação haitiana vivencia grandes desafios na atualidade. De um lado a fomentação pela ampliação estatística de uma "educação para todos" e de um país sem analfabetos; do outro, a necessidade, gritante, por maiores investimentos, na formação inicial e continuada dos professores, reparação e adequação das estruturas físicas das escolas e, é claro, maior preocupação e comprometimento com a sua qualidade.

\section{Metodologia e relato de campo}

Essa pesquisa teve como base a Teoria das Representações Sociais. As Representações Sociais se articulam à vida social de um grupo e também à construção simbólica do indivíduo em particular. $\mathrm{O}$ estudo é fruto de um recorte dos resultados do Projeto "Geopedagogia: a escola em mapas 
mentais de alunos brasileiros, haitianos e bolivianos", vinculado ao Programa Institucional de Pesquisa do Instituto Federal de Educação, Ciência e Tecnologia de Rondônia (IFRO).

O objetivo geral do projeto foi conhecer representações sobre a escola de alunos brasileiros, bolivianos e haitianos por meio de mapas mentais. O projeto teve como suporte teórico-metodológico a aplicação de mapas mentais, proposto por Kozel (2007). Esse relato aborda a análise dos dez mapas mentais produzidos por crianças em uma escola haitiana, nos arredores de Porto Príncipe, no ano de 2015.

O mundo cultural, para Kozel (2007), não é uma soma de objetos, mas uma forma de linguagem referenciada nos sistemas de relações sociais. $\mathrm{E}$ os mapas mentais são imagens que apresentam valores, atitudes e vivências que permeiam essas relações. Assim sendo, os mapas mentais são aqui compreendidos como enunciados que apresentam construções sígnicas, as quais estão inseridas em contextos sociais, espaciais e históricos coletivos, apresentando particularidades e singularidades. Consideramos a imagem como um elemento de estudo, que comporta informações de um contexto espacial e, também, pode ser a expressão visual de experiências subjetivas.

O dualismo que distingue a relação da criança com o âmbito escolar em cognitiva e afetiva, defendido por algumas concepções educacionais, é um mito (VASCONCELOS, 2004). É importante destacar a ação do sujeito no mundo em que vive, assim como já propuseram estudos no campo da Psicologia da Educação, sobretudo em Piaget, Wallon e Vygotsky que convergem na visão de que o conhecimento se dá a partir do sujeito em sua ação no mundo e conferem a esse processo sujeito-mundo uma dialeticidade ímpar nas teorizações sobre como conhecê-lo (PEREIRA, 2012).

É nesse aspecto que enfatizamos as contribuições de Vygotsky (1989; 2001). Os estudos vygotskyanos nos ajudaram a perceber as noções de representação e simbolismo com base na experiência da criança. A fala, por exemplo, possui um endereçamento ao outro. "A fala para si mesmo origina-se da fala para os outros” (1989, p. 114). Desse modo não apenas a fala é componente estruturante do pensamento, mas o outro a quem ela se destina também. "A linguagem não serve como expressão de um pensamento 
pronto". Assim, “[...] ao transformar-se em linguagem, o pensamento se reestrutura e se modifica. $O$ pensamento não se expressa, mas se realiza na palavra" (2001, p. 412).

A questão norteadora foi: o que é a escola para você? Para realizar os mapas, os alunos receberam materiais para desenho e pintura. Para interpretar os mapas mentais, conforme já dito, optamos pelos procedimentos descritos por Kozel (2009). De acordo com essa metodologia, os conteúdos são analisados pelos seguintes pontos: 1 - Interpretação quanto à forma dos elementos na imagem; 2 - Interpretação quanto à distribuição dos elementos na imagem; 3 - Interpretação quanto à especificidade dos ícones a serem observados nos elementos da paisagem natural; elementos da paisagem construída; elementos móveis e imóveis; elementos humanos); e, por fim, analisa-se; 4 - Apresentação de outros aspectos particulares.

Para complementar as análises, observam-se ainda os seguintes aspectos: a) como as formas aparecem nas imagens? (letras, em forma de mapas, linhas, figuras geométricas); b) a distribuição dos elementos: (horizontalmente, isolados, forma dispersa, em perspectiva, circular). Identificam-se, assim, as formas, as expressões em forma de letras ou palavras que complementam o desenho com uma explicação na linguagem formal.

Os mapas mentais são desenhos concebidos pelas observações sensíveis da experiência humana no lugar e não se baseiam em informações precisas e rigorosamente estabelecidas, porque "a razão objetiva [...] se refere à existência humana mesmo que esta não possa ser expressa em categorias de quantidade", (HOLZER, 2006, p. 202).

Ao analisar os mapas mentais, é preciso, portanto, não pensar neles como meros desenhos sem sentido, e focar na intenção do que se quis representar, como aponta KOZEL (2007).

Os encontros, as vivências do lugar, gravados na memória das pessoas, possibilitam a construção dos mapas mentais, as ferramentas utilizadas em estudos com mapas mentais (LIMA; KOZEL, 2009).

O trabalho de campo foi realizado de modo informal com crianças haitianas entre 7 a 10 anos, todas em processo de escolarização. 
Foram produzidos dez mapas mentais, mas, para esse estudo, analisamos somente cinco.

Inicialmente, solicitou-se às crianças que pensassem na escola deles. Depois, apresentou-se a questão norteadora com o pedido de que elas desenhassem o que era a escola para elas, a escola delas.

Todas as crianças foram muito participativas. A comunicação foi realizada via professor/mediador haitiano, a fim de nos assegurarmos de que os procedimentos eram bem compreendidos. Ainda assim, não se pode assegurar de que o método foi corretamente aplicado, como foi no Brasil, já que a comunicação se realizou de forma mediada. Outro aspecto a destacar é que a discussão e o relato individual das crianças após a produção dos mapas também foi mediada pelo tradutor, isto significa que a leitura dos mapas mentais não partiu diretamente das crianças, mas da descrição dada por quem mediava o diálogo.

Afora essas dificuldades, a experiência foi bastante enriquecedora, com duração de aproximadamente 40 minutos.

\section{Análise: uma leitura da escola por crianças haitianas}

Foram analisados cinco mapas mentais produzidos por crianças haitianas com a pergunta norteadora "O que é a escola para você?".

$\mathrm{Na}$ intepretação do Mapa 1, considera-se o que Kozel (2007) propõe, na observação dos seguintes aspectos: quanto à forma de representação dos elementos na imagem, observamos letras, ícones diversos, linhas e figuras geométricas. Quanto à distribuição dos elementos na imagem, verificamos que estão dispersas horizontalmente, mais para o lado direito, o lado esquerdo foi pouco preenchido. Quanto às especificidades dos ícones, constatamos elementos da paisagem construída, elementos humanos e elementos móveis. Quanto a outros aspectos ou particularidades, evidenciamos o colorido, várias bandeiras do Haiti, elemento humano com expressão de tristeza, um caminho que expressa o percurso do aluno até chegar à escola, o elemento móvel “ônibus” também com a bandeira. O ônibus está vazio e 
o que se pode enxergar é apenas a cadeira do motorista e o volante. A escola é representada por turmas diferentes em um mesmo espaço.

Um fato curioso é que a escola foi representada sem porta. Esse fato pôde ser constatado durante as visitas às escolas da região de Bom Repos, onde a maioria delas possui apenas a construção de paredes, mas sem portas ou janelas, ficando, assim, abertas o tempo todo, mesmo quando não há atividades na escola.

Figura 1 - Mapa Mental A

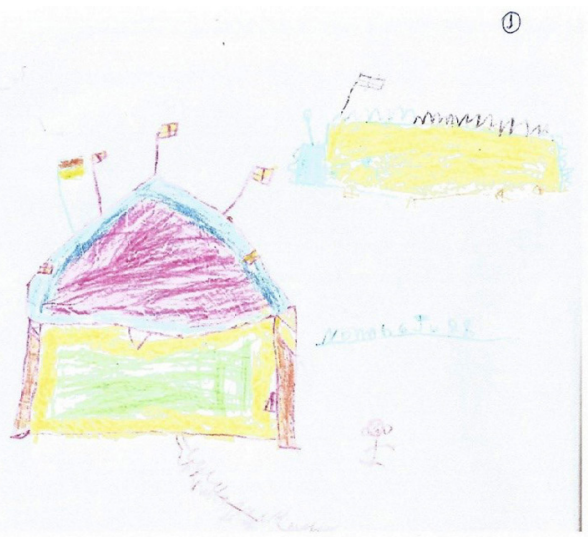

Fonte: Coleta de dados, Projeto Geopedagogia, 2014-2015, estudante haitiano, 5 anos

O aluno haitiano de Porto Príncipe, que fez o Mapa Mental A, retratou sua escola com muitas cores, azul, roxo, amarelo, verde e desenhou quatro bandeiras, uma do seu país - Haiti, do lado externo da escola, e duas em cada lado do telhado; há duas colunas que sustentam a escola e uma área livre em verde e amarelo, um pequeno caminho que vai até a escola, porém não tem uma porta de acesso. O elemento móvel, ônibus, foi retratado logo acima da escola, como se o veículo estivesse distante da escola; também podemos observar a bandeira do Haiti, no lado externo do ônibus. As bandeiras nos mostram a percepção das diferentes nacionalidades que estão presentes no território haitiano. Ainda que as disputas e conflitos possam não ser entendidas em profundidade pelas crianças, o mapa mental nos remete para o fato de que elas possuem a compreensão de que há um jogo de ingerência estrangeira em seu país ou, ao menos, que há a presença de 
elementos diversos que interagem em seu território e que sobre ele exercem algum tipo de poder.

$\mathrm{Na}$ intepretação do Mapa B, a seguir, considera-se o que Kozel (2007) propõe pelos seguintes aspectos: quanto à forma de representação dos elementos na imagem, observamos letras, ícones diversos, linhas e figuras geométricas. Quanto à distribuição dos elementos na imagem, verificamos que está centralizado verticalmente, mais para o lado esquerdo. Quanto às especificidades dos ícones, constatamos elementos da paisagem construída. Quanto a outros aspectos ou particularidades, evidenciamos as cores do Brasil, bandeira do Haiti com as cores do Brasil fora da escola e bandeira do Brasil dentro da escola.

Figura 2 - Mapa Mental B

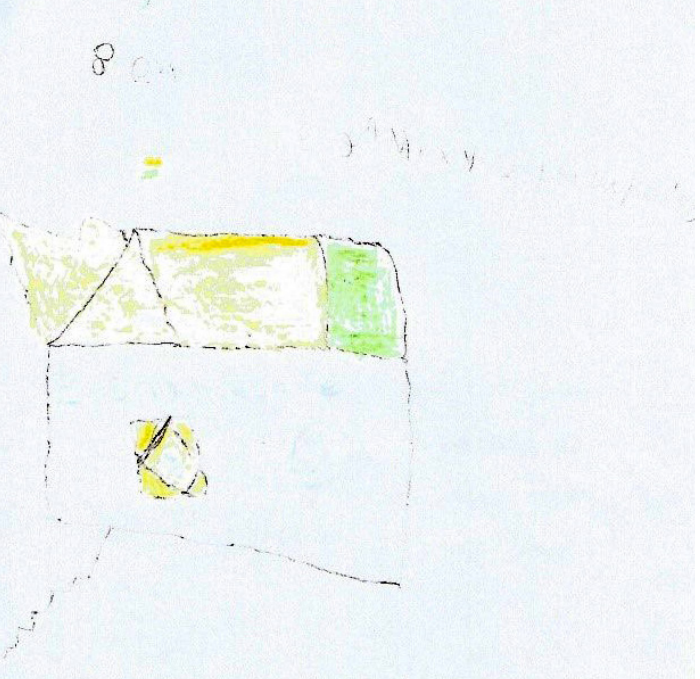

Fonte: Coleta de dados, Projeto Geopedagogia, 2014-2015, estudante haitiano, 8 anos

O aluno haitiano de Porto Príncipe que produziu o Mapa B, representado na Figura 2, retratou sua escola num formato de uma casa mais 'universal', com as cores do Brasil, o verde e o amarelo. Podemos perceber que a bandeira do Brasil está dentro da escola, a bandeira haitiana no lado externo da escola também representada pelas cores verde e amarelo. $\mathrm{O}$ caminho que está ligado à escola também se faz presente nesse mapa. 
Algumas letras grafadas sem a formação de palavras indicam que o estudante está no início do processo de alfabetização.

A escolha das cores verde e amarelo está relacionada à influência da presença da pesquisadora que é brasileira, mas também à presença brasileira em geral no país por meio da Missão das Nações Unidas para a estabilização no Haiti (MINUSTAH). Além disso, a seleção brasileira de futebol foi lembrada na fala do estudante sobre o mapa que desenhou, ainda que considerando seleções de outros países com prestígio crescente à época. Observou-se que o futebol é um elemento de identificação entre as crianças e o Brasil.

$\mathrm{Na}$ intepretação do Mapa $\mathrm{C}$, considera-se: quanto à forma de representação dos elementos na imagem, observamos figuras geométricas; quanto à distribuição dos elementos na imagem, verificamos que está verticalmente em toda a folha; quanto às especificidades dos ícones, constatamos elementos da paisagem construída, elementos humanos; quanto a outros aspectos ou particularidades, evidenciamos que as divisões querem dizer várias turmas, mas, em uma sala só, pois não há paredes na escola, e a bandeira do Haiti está presente no lado externo da escola.

Figura 3 - Mapa Mental C 
A escola foi retratada com várias cores, azul, amarelo, verde, roxo e vermelho. $\mathrm{Na}$ observação in loco, constatamos que a escola é multisseriada. $\mathrm{O}$ estudante fez uma representação das turmas por meio de diferentes cores. Uma divisão que transcende o que existe fisicamente na escola. As bandeiras do Haiti também estão presentes no lado externo da escola. Há um elemento humano que pode ser o próprio aluno, ou o que se parece mais com uma borboleta, está do lado de fora olhando a escola.

$\mathrm{Na}$ intepretação do Mapa $\mathrm{D}$, considera-se: quanto à forma de representação dos elementos na imagem, observamos linhas e figuras geométricas. Quanto à distribuição dos elementos na imagem, verificamos que está verticalmente em toda folha. Quanto às especificidades dos ícones, constatamos elementos da paisagem construída, elementos humanos. Quanto a outros aspectos ou particularidades, evidenciamos uma divisão no meio da escola, com duas portas fechadas; as salas de aula são divididas por cores, sem paredes, e a bandeira do Haiti fica do lado externo da escola.

\section{Figura 4-Mapa Mental D}

Fonte: Coleta de dados, Projeto Geopedagogia, 2014-2015, estudante haitiano, 10 anos

A escola foi retratada com poucas cores e pinturas. Do mesmo modo que o mapa $\mathrm{C}$, o estudante representou sua escola multisseriada, realidade bastante presente no Haiti. Mas, assim como as escolas, o sistema educacional haitiano é marcado pela divisão de classes. 
O sistema educacional haitiano é um sistema com várias velocidades. Cada escola é como um sistema de ensino separado. Há escolas nacionais, congregacionais, presbiterais e comunais. Cada um desses subgrupos é como um sistema educacional formando haitianos diferentes, com diferentes habilidades, objetivos diferentes e quase incapazes de viverem juntos. $\mathrm{O}$ atual sistema de ensino não tem meios de sua política nem meios educacionais, nem recursos humanos para garantir o seu funcionamento adequado (CHARLES, 2015).

$\mathrm{Na}$ intepretação do Mapa E, consideram-se os seguintes aspectos: quanto à forma de representação dos elementos na imagem, observamos linhas e figuras geométricas. Quanto à distribuição dos elementos na imagem, verificamos que está centralizado verticalmente. Quanto às especificidades dos ícones, constatamos elementos da paisagem construída. Quanto a outros aspectos ou particularidades, evidenciamos muitas cores, escola de múltiplas séries e as cores são as turmas. A escola está com a porta fechada, e a bandeira do Haiti está no lado externo da escola.

Figura 5 - Mapa Mental E

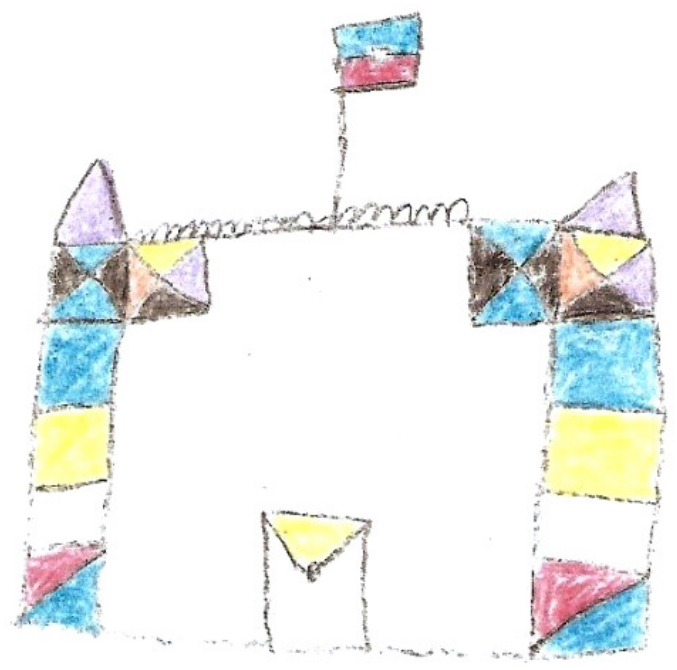

Fonte: Coleta de dados, Projeto Geopedagogia, 2014-2015, estudante haitiano, 8 anos 
Nesse mapa, a escola foi representada com cores mais fortes, azul e vermelho, que são as cores da bandeira haitiana. Cada cor representa séries diferentes, pois a escola, assim como tantas outras escolas no Haiti, é multisseriada; também percebemos que a essa divisão é feita por formas geométricas, o quadrado e o triângulo.

De certo modo, a presença da bandeira haitiana na representação dos mapas mentais da maioria dos estudantes possui relação com a construção da sua identidade, tanto da escola quanto das pessoas. Por muito tempo, não existiu um sistema educacional haitiano e, atualmente, pode-se dizer que cada escola é um sistema, pois suas regras e organização são definidas pela própria escola, conforme descrito por Charles (2015). O difícil acesso até a escola é indiciado nos mapas tanto pelo longo percurso quanto pela presença de ônibus em diferentes mapas, e a organização multisseriada das escolas foi destacada por meio de cores.

\section{Considerações finais}

A educação escolar no Haiti, como vimos, ainda não é um projeto de desenvolvimento nacional, considerando os dados de que apenas $50 \%$ das crianças estão na escola e, destas, $80 \%$ estão em escolas privadas.

Os mapas mentais foram produzidos por crianças entre 5 e 10 anos. A escola, de modo geral, foi representada como ícone de pertencimento nacional por meio da representação da bandeira do Haiti em quase todos os mapas. As dificuldades de acesso à escola foram representadas por meio de condução, essencialmente pelo ônibus. $\mathrm{O}$ ambiente físico da escola foi bem delimitado pelas crianças, demonstrando uma experiência da estrutura e do funcionamento de salas multisseriadas.

Um aspecto importante a destacar é que o elemento humano esteve praticamente ausente dos mapas mentais das crianças haitianas. A percepção da escola esteve muito mais relacionada ao aspecto físico da organização didática e ao percurso até a escola do que à interação social no espaço escolar. Pensar sobre essas e outras ausências que estiveram tão presentes em mapas mentais de outras crianças, das bolivianas e brasileiras e até das 
crianças haitianas no Brasil, por exemplo, requer esforço de análise interessante e deve instigar estudos posteriores.

A pesquisa possibilitou a experiência de cartografar o que é a escola para o aluno que expressa um modo de falar ao outro como se o desenho fosse para si mesmo, entretanto, em um contexto da experiência em que tanto a fala quanto o outro são componentes estruturantes do pensamento. No caso das crianças haitianas, ficou evidente que essa cartografia se expressa por meio das dificuldades de acesso à escola, assim como pelas experiências diversificadas em salas de aula multisseriadas, do pertencimento nacional em meio a ingerências de outras nacionalidades no terrritório haitiano e da expectativa de inclusão social por meio da escola.

\section{Referências}

CHARLES, Vagner. Análise da identidade e da alteridade no sistema educacional haitiano. Dissertação (Mestrado em Educação) - Programa de Pós-Graduação da Faculdade de Educação da Universidade Estadual de Campinas - UNICAMP. Campinas, SP: UNICAMP, 2015. Disponível em: http://repositorio.unicamp.br/bitstream/REPOSIP/254005/1/Charles_Vagner_M.pdf. Acesso em: 10 de mar. de 2019.

GRONDIN, Marcelo. Haiti: cultura, poder e desenvolvimento. São Paulo: Editora Brasiliense, 1985 .

HOLZER, Werther; HOLZER, Selma. Cartografia para crianças: qual é o seu lugar? In: SEEMANN, J. (Org.): A aventura Cartográfica: Perspectivas, pesquisas e reflexões sobre a cartografia humana. Fortaleza - CE, Expressão Gráfica, 2006. p.201-217.

LIMA, Angélica Macedo Lozano; KOZEL, Salete. Lugar e mapa mental: uma análise possível. Geografia, v.18, n.1, jan./jun. 2009 - Universidade Estadual de Londrina, Departamento de Geociências.

KOZEL, Salete; SILVA, Josué da Costa; GIL FILHO, Sylvio Fausto. (Org.). Da percepção e cognição à representação: reconstruções teóricas da Geografia Cultural e Humanista. São Paulo: Terceira Margem: Curitiba: NEER, 2007.

MACPHERSON, John. Caribbean Lands - A geography of West Indies. Longmans, Green And CO LTD. 1963.

MOSCOVICI, Serge. Representações Sociais: investigações em psicologia social. Trad. Pedrinho Guareschi. 7. ed. Petrópolis, RJ: Vozes, 2010

MOSCOVICI, Serge. As linguagens do cotidiano como representações do espaço: uma proposta metodológica possível. In: ENCUENTRO DE GEÓGRAFOS DA AMÉRI- 
CA LATINA: caminando en una américa latina en transformación, 2, 2009, Montevideo, Anais.... Montevideo: Universidad de la República, 2009, CD-ROM. ISBN: 978-99748002-8-1.

PEREIRA, Caciana Linhares. Piaget, Vygotsky e Wallon: contribuições para os estudos da linguagem. Psicologia em Estudo, Maringá, v. 17, n. 2, p. 277-286, abr./jun. 2012. Disponível em: http://www.scielo.br/pdf/pe/v17n2/v17n2a10.pdf. Acesso em: 10 de jul. 2015.

VASCONCELOS, Mário Sérgio. Afetividade na escola: alternativas teóricas e práticas. Educ. Soc., Campinas, v. 25, n. 87, p. 616-620, maio/ago. 2004. Disponível em: http://www. scielo.br/pdf/es/v25n87/21472.pdf. Acesso em: 6 de jul. de 2015.

VYGOTSKY, L. S. Pensamento e linguagem. 2 ed. São Paulo: Martins Fontes, 1989.

VYGOTSKY, L. S. A construção do pensamento e da linguagem. São Paulo: Martins Fontes, 2001. 

PARTE 2 



\section{MAPAS MENTAIS E FORMAČ̃̃ DE \\ PROFESSORES: REPRESENTAČÕES DOS OLHARES DOS DISCENTES PARA A MATEMÁTICA}

Gislaina Rayana Freitas dos Santos

\section{Introdução}

O presente artigo discute o olhar dos alunos bolivianos para a escola, ou seja, sobre as representações que descrevem a escola tendo em vista os conceitos dos educandos do ensino secundário das escolas bolivianas. Nesse sentido, o olhar dos pesquisadores consiste em desenvolver as representações dos alunos no contexto dos mapas mentais como um método de pesquisa.

Conforme Kozel (2005), os mapas mentais constituem-se como instrumentos valiosos para retratar o espaço vivido, com todas as suas nuances e construções sociais. Por esse meio, o educando representa, através de desenho, as suas concepções sobre a escola, constituídas por signos ao longo de toda a sua vida escolar. Por isso, suas representações são consideradas, segundo a teoria de Kozel (2005), uma linguagem impregnada de significados e valores sociais que refletem a realidade ou a vivência social do indivíduo.

Os mapas mentais são produtos de construções sociais e de experiências culturais, das quais os alunos se apropriam ao longo da trajetória escolar. Nesse contexto, iremos refletir sobre a construção da imagem interrelacionada com a apreensão do significado e da subjetividade contidas nos

\footnotetext{
${ }^{1}$ Mestranda do Programa de Pós-graduação Stricto Sensu em Educação pela Universidade Federal de Rondônia-UNIR, Especialista em Metodologia do Ensino Superior e EAD pela Faculdade Educacional da Lapa-FAEL, Pós-graduanda em História e Cultura Afro-Brasileira e Africana pelo Instituto Federal do Amazonas-IFAM, Pedagoga Formada pela Universidade Federal de Rondônia-UNIR, graduanda em Serviço Social pela Universidade Paulista-UNIP, Pesquisadora do grupo GEIFA - Grupo de Estudos Interdisciplinares da Fronteira Amazônica.e-mail: rayana2008@hotmail.com
} 
signos. Sobre esse aspecto, Richter (2011) acrescenta que os mapas mentais materializam as interpretações, os olhares, as reflexões, os avanços, as relações, os limites, as experiências e os sentimentos dos indivíduos. Assim, a pesquisa foi sendo desenvolvida no interesse de conhecer e de compreender as concepções de escola internalizadas pelos alunos bolivianos. Esse processo foi construído em consonância com as perspectivas de Libâneo (2010, p.27) para o qual "[...] a escola precisa articular sua capacidade de receber e interpretar informação com a de produzi-la, a partir do aluno como sujeito do seu próprio conhecimento". Nesse sentido, no contexto em que estabelece os olhares dos alunos, representados pelos mapas mentais, a escola, como a base dessa relação, precisa conceber os mapas mentais como mecanismos decodificadores de signos que demonstram o mundo escolar vivido pelos alunos.

O objetivo deste artigo foi refletir sobre o espaço que a matemática ocupa na formação dos alunos do nível da educação secundária, a partir das representações da escola produzidas, reflexão ancorada na metodologia dos mapas mentais. No que concerne ao processo metodológico, a pesquisa de cunho qualitativo e de natureza descritiva tem como aspecto norteador a observação direta, pela construção e análise de mapas mentais, fazendo as interpretações das imagens e seguindo a metodologia proposta por Kozel (2018). Escolhemos os Mapas Mentais como instrumento metodológico que oferece a coleta de dados e informações necessários para trabalhar de forma concreta. Além disso, essa metodologia oferece uma linguagem privilegiada para a comunicação dos aspectos constitutivos do espaço vivido e percebido pelo aluno no contexto escolar e social.

Nessa condição, a pesquisa buscou descrever os olhares dos alunos bolivianos, representados nos Mapas Mentais, com a perspectiva de buscar compreender o mundo vivido por esse aluno, na dimensão em que o indivíduo imprime, no mundo particular, uma cultura representada pelas relações sociais entre o ser humano e o ambiente. 


\section{Mapa mental como instrumento de pesquisa em educação}

O Mapa Mental constitui-se numa metodologia que visa representar as condições, processos, fatos e o espaço cotidiano do mundo humano. Nesse sentido, a imagem carrega consigo valores socioculturais representados pelo desenho, que constitui a primeira representação gráfica utilizada pelos indivíduos. Desenhar é um ato inteligente de representação que põe forma e sentido ao pensamento, como, também, à constituição do espaço vivido. O desenho é uma ferramenta essencial do processo de desenvolvimento psicomotor e não deve ser entendido como uma atividade complementar, ou de só divertimento, mas como uma atividade funcional. Seguindo as concepções de Piaget (1973), o desenho é uma manifestação semiótica, isto é, uma das formas pelas quais a função de atribuição da significação se expressa e se constrói. O desenho estabelece um elo de participação entre o indivíduo e o mundo, evocando e despertando formas, imagens, significados, através de seus recursos materiais.

Com intenção de representar um objeto, o desenho compõe as representações sígnicas contidas nos signos decodificados nos mapas mentais, seguindo as concepções de Pierce (apud Wanner, 2010, p.38), que considera signo como:

[...] aquilo que, sob certo aspecto ou modo, representa algo para alguém. Dirige-se a alguém, isto é, cria, na mente dessa pessoa, um signo equivalente, ou talvez um signo mais desenvolvido. Ao signo assim criado denomino interpretante do primeiro signo. $\mathrm{O}$ signo representa alguma coisa, seu objeto. Representa esse objeto não em todos os seus aspectos, mas com referência a um tipo de ideia.

Os signos compreendem o processo de intercomunicação e aprendizagem. Um exemplo clássico dessa atividade são as nossas representações mentais, que são desenvolvidas pela composição dos signos, construindo, nesse contexto, os conceitos, as ideias e as crenças, além de construir a compreensão da realidade quanto à ação no mundo. 
Para Vygotsky (1998), o signo constitui um meio da atividade interna dirigida para o controle do próprio indivíduo, orientado internamente. Podemos concluir que signo é algo que representa alguma coisa para alguém em determinada circunstância, como também que o signo está no lugar de algo, não é a própria coisa, mas como ela se faz presente para alguém em certo contexto. Algo pode personificar-se por meio de signos diversos, decodificado pelo desenho na representação do mapa mental.

Entendemos que as representações que compõem o mapa mental, como uma expressão do vivido, de uma maneira não linear ao ato da leitura e compreensão, que possibilita uma visão do conjunto, concedendo ao leitor uma autonomia para seguir diversos caminhos (RICHTER, 2011). Nesse campo, seguimos o caminho do espaço que a matemática ocupa nas concepções dos alunos bolivianos, representados pelos mapas mentais da prática e da vivência da matemática na sala de aula. Para isso, refletimos sobre o significado de espaço, inicialmente, por uma linguagem denotativa, em que espaço vem do latim spat囚um e que admite diversas acepções. Para o dicionário Aurélio (2005), é a distância entre dois pontos, ou área ou o volume entre linhas determinadas, como também lugar mais ou menos bem delimitado, cuja área pode conter alguma coisa. Seguindo as reflexões para Wanner (2010), o conceito de espaço é entendido da seguinte maneira:

[...] etimologicamente, o espaço possui vários significados; para Platão, o espaço chama-se chora, antes do termo topos e na Grécia antiga esse termo também é denominado de caos, bem como vazio. 'As metáforas do Timaeus são obscuras, mas delas se pode extrair que Platão o pensou sobre o espaço como um recipiente e a matéria nesse recipiente como um mero espaço vazio limitado por superfícies geométricas'. [Definição refutada por Aristóteles, que tentou contornar essa dificuldade ao tratar o conceito de espaço como lugar, topos, ou seja,] 'a fronteira interior daquilo que contém a fronteira adjacente de um corpo nele contido. Sua intenção parece ter sido definir lugar em relação ao cosmos como um todo' [...]. [A palavra cosmos foi] 'enunciada pela primeira vez por Homero [...] como um princípio do universo no seu todo', e espaço e 
tempo eram traços da natureza [...] o conceito de espaço passa a ter um estatuto psíquico, social e histórico que apresenta uma multiplicidade transbordante de facetas (WANNER, 2010).

Nessa perspectiva, o espaço ganha diferentes significados e compreensões. Para tanto, seguimos as concepções de Piaget (1967), ao afirmar que a noção de espaço e sua representação não derivam simplesmente da percepção: é o sujeito, mediante a inteligência, que atribui significados aos objetos percebidos, enriquecendo e desenvolvendo a atividade perceptiva. Em síntese, em todos os níveis de desenvolvimento, as informações fornecidas pela percepção - e também pela imagem mental - servem de material bruto para a ação ou para a operação mental. Por sua vez, essas atividades mentais exercem influência direta ou indireta sobre a percepção, enriquecendo-a e orientando o seu funcionamento, à medida que se processa o desenvolvimento mental.

Dessa forma, a percepção não implica uma mera cópia da realidade, mas, sim, um processo construtivo, mediante a interpretação dos sentidos. Falar em "realidade" nos conduz para o espaço da percepção e das experiências humanas (SANTAELLA, apud WAGNER, 2010). Realidade das quais o conceito de espaço passa a ter um estatuto psíquico, social e histórico que apresenta uma multiplicidade transbordante de facetas.

Escolhemos os Mapas Mentais como instrumento metodológico que oferece os elementos necessários para trabalhar de forma concreta, por oferecer uma linguagem privilegiada para a comunicação dos aspectos constitutivos do espaço vivido e percebido pelos alunos na escola, seguindo as reflexões da importância para a decodificação dos signos, representados pelos desenhos que contêm significados objetivos e subjetivos das concepções de escola para os alunos bolivianos.

\section{0 contexto da pesquisa no espaço escolar boliviano}

Este artigo expressa as representações dos alunos bolivianos para o lugar que a matemática ocupa na percepção dos próprios alunos nas atividades e vivências desenvolvidas nas aulas de matemática. Para tanto, 
buscamos compreender, de forma sintética, como funciona o Sistema Educacional boliviano.

O Sistema Educacional boliviano é organizado pela Lei da Educação no 070 (Lei “Avelino Siñani - Elizardo Pérez"), de 20 de dezembro de 2010. Essa lei assegura a educação como um direito universal para todos os habitantes do Estado Plurinacional, constituído na sociedade, com a plena participação de bolivianos no sistema de ensino, respeitando suas diversas expressões sociais e culturais em suas diversas formas de organização.

[Base da Educação] É produtivo e territorial, orientada intelectual e da produção material, o trabalho criativo e a relação harmoniosa dos sistemas e comunidades humanas vivendo na Mãe Terra, o fortalecimento da gestão territorial das nações e dos povos indígenas nativos, comunidades interculturais e afro-boliviano [...] É educação para a vida e na vida, para viver bem. Desenvolver uma educação integral que promove a realização de identidade, emoções, espiritualidade e subjetividade das pessoas e comunidades; É viver em harmonia com a Mãe Terra e da comunidade entre os seres humanos. (BOLÍVIA, 2010, p. 6, tradução nossa).

A Lei estrutura a Educação boliviana como Sistema Educativo Plurinacional, que envolve a Educação Regular - dividida em três níveis: Educação Inicial em Família Comunitária: com cinco anos de duração, sendo: três anos na Educação Inicial em Família não Escolarizada e dois anos na Educação Inicial em Família Escolarizada; Educação Primária Comunitária Vocacional: com seis anos de duração, sendo: a formação qualitativa para a formação básica, fundamental como base para o processo de formação posterior; Educação Secundária Comunitária Produtiva: com seis anos de duração, sendo: grau técnico médio, como formação em Bacharel Técnico Humanístico.

O Sistema da educação boliviana também contempla a Educação Alternativa e Especial - para jovens e adultos com mais de 15 anos que pretendem continuar seus estudos, a Educação Especial assegura o direito ao ingresso e permanência de pessoas com necessidades educativas especiais (na lei são pessoas com incapacidade, com dificuldade de aprendizado 
e com talento extraordinário). E a Educação Superior de Formação profissional - visa ao desenvolvimento de competências e habilidades artísticas, articulando teoria e prática, para fortalecer as expressões culturais e o desenvolvimento de qualidades criativas.

3.1 Comparando a estrutura curricular e o currículo de Matemática

Neste tópico, apresentamos um panorama da estrutura curricular dos países Brasil e Bolívia, para compormos um cenário no qual desenvolveremos as análises dos mapas mentais. No tópico anterior, descrevemos o Sistema Educativo Plurinacional, o qual é regido pela Lei no 070. Neste tópico, vamos apresentar os pressupostos da Educação brasileira, que é regida pela Lei de Diretrizes e bases da Educação Nacional - LDBN no. 9394/96.

O Sistema de Educação Brasileira está dividido em Educação Básica, Educação de Jovens e adultos (EJA), Educação de campo, Educação Especial e Educação Superior. A Educação Básica compreende: 1. Educação Infantil com duração de 4 anos; a Creche atende crianças de 0 a 3 anos de idade, e a Pré-escola, crianças de 4 e 5 anos, com 2 anos de duração. A Educação Infantil tem por objetivo o desenvolvimento integral da criança em seus aspectos físicos, psicológicos, intelectuais e sociais, contidos no artigo 29 da LDB; 2. Ensino fundamental é destinado a crianças e adolescentes com duração mínima de 9 anos, com o objetivo de formação básica do cidadão; 3. Ensino Médio, com estudos de 3 anos, é a etapa final da educação básica, cuja finalidade é preparar os jovens para o ingresso na universidade, por meio da promoção do pensamento crítico, contidos no artigo 35 da LBD "o aprimoramento do educando como pessoa humana, incluindo a formação ética e o desenvolvimento da autonomia intelectual e do pensamento crítico; e 4. Ensino Médio Técnico, em que as escolas podem oferecer cursos técnicos em períodos contra turnos, que são períodos extraclasse para seus alunos. A duração é variável, podendo ser de 1 a 3 anos.

A Educação de Jovens e Adultos (EJA) atende indivíduos que não tiveram a oportunidade de cursar o Ensino Fundamental ou Médio na 
idade prevista. É desenvolvida por meio de módulos, sendo que seis meses equivalem aos anos do ensino regular.

Educação no campo, desenvolvida em escolas que estão longe dos centros urbanos, localizadas nas zonas rurais, em que a escola adapta-se às peculiaridades da vida rural de cada região, compondo seus próprios currículos, métodos didáticos e calendário escolar.

Educação Especial é a modalidade para educandos portadores de necessidade especiais; são escolas que possuem adaptações físicas e materiais que facilitam o ensino dos indivíduos com algum tipo de deficiência física ou mental.

Ensino Superior compreende a graduação, a pós-graduação (Especialização,

Mestrado, doutorado e pós-doutorado), como também as modalidades de ensino a distância. A duração varia, conforme o curso, de 3 a 6 anos, para a graduação; de 2 anos para mestrado e 4 anos para doutorado.

Quadro 1 - Sistema de Educação - Brasil

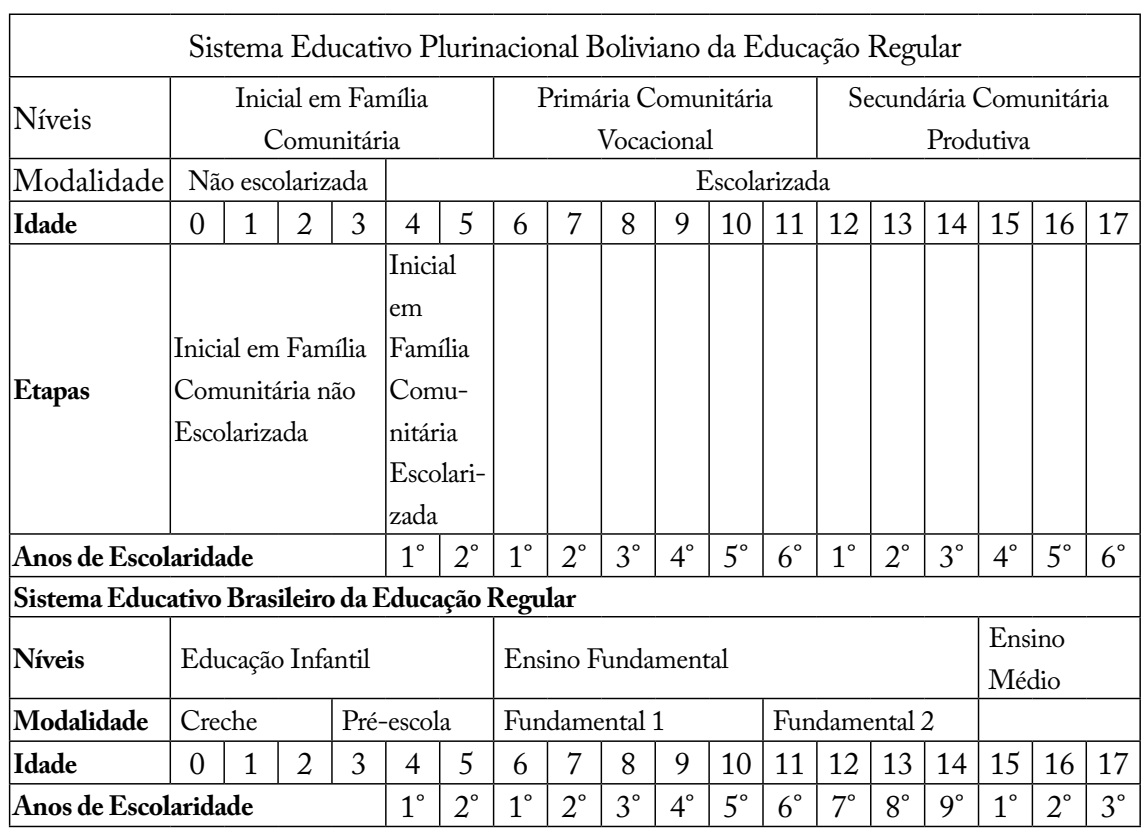

Fonte: Base curricular do Ministério da Educação Boliviana e Mistério da Educação Brasileira, elaborado pela autora 
Como já apresentamos o panorama da educação dos dois países, vamos comparar a estrutura curricular e, com isso, compor um cenário da educação matemática o que contribuirá para as reflexões sobre o currículo de matemática nos países relacionados. A matemática possui em seu contexto contribuições consideradas benéficas e positivas para a educação em geral. Nesse sentido, Godoy (2015) propõe quatro metas para a educação matemática, relacionando-as com as metas gerais da educação e as necessidades da sociedade, tais como:

[...] determinar para cada indivíduo, competências matemática que lhe cabe; preparar cada indivíduo para vida adulta, reconhecendo que alguns requerem mais instrução matemática que outros; estimular o reconhecimento fundamental da utilidade da matemática em nossa sociedade; desenvolver habilidade para usar modelos matemáticos com vista à resolução de problemas. (GODOY, 2015, p.116).

Seguindo as concepções de Godoy (2015), o currículo da educação escolar é organizado com base nas disciplinas escolares, e essas são responsáveis pela distribuição do saber escolar. Nesse sentido, o currículo tem a intenção de oferecer propostas concretas sobre modos de entender o conhecimento, de interpretar a aprendizagem, que constitui um plano de formação para o desenvolvimento e a promoção do aluno. Destacamos que o currículo deve motivar os alunos para o interesse e a capacidade, criando condições para sua inserção num mundo em mudanças e contribuindo para a construção de capacidades que deles serão exigidas em sua vida social e profissional. É nesse contexto que o currículo de matemática precisa ser articulado. A seguir, apresentamos os blocos de conteúdos que poderão ser desenvolvidos nos anos iniciais do Ensino Fundamental (primeiro ciclo) no Brasil e os blocos de conteúdos que poderão ser desenvolvidos no ensino Primário e Secundário na Bolívia. 
Quadro 2 - Blocos de conteúdos dos níveis equivalentes ao Ensino Fundamental 1 Brasil - Primária Comunitária Vocacional - Bolívia

\begin{tabular}{|c|c|c|c|}
\hline & Bolívia & & Brasil \\
\hline & $\begin{array}{l}\text { - Noções de espacialidade, tem- } \\
\text { poralidade, seriação e classificação } \\
\text { com elementos do seu ambiente } \\
\text { imediato } \\
\text { • Noção de conjuntos, com ele- } \\
\text { mentos do seu ambiente imediato } \\
\text { - Figuras geométricas planas na } \\
\text { esfera da comunidade } \\
\text { - Quantidade e representação sim- } \\
\text { bólica de números naturais }\end{array}$ & & $\begin{array}{l}\text { Números e operações } \\
\text { • Números naturais } \\
\text { • números inteiros, positivos e } \\
\text { negativos, } \\
\text { - números racionais } \\
\text { - números irracionais } \\
\text { - Situações problemas envolvendo } \\
\text { adição, subtração, multiplicação, } \\
\text { divisão, potencialização e } \\
\text { radiciação } \\
\text { - Álgebra }\end{array}$ \\
\hline 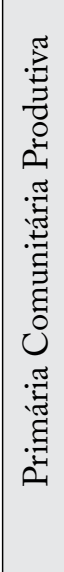 & $\begin{array}{l}\text { - Números naturais na linha } \\
\text { numérica } \\
\text { • Números ordinais na organização } \\
\text { da família e da escola } \\
\text { • Formas geométricas no ambiente } \\
\text { natural e arquitetônico } \\
\text { • Contextualização e descontextua- } \\
\text { lização dos elementos do contexto } \\
\text { com números naturais } \\
\text { - Relação de equivalência com } \\
\text { números naturais }\end{array}$ & 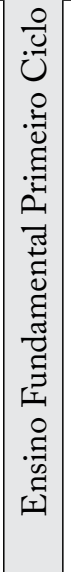 & $\begin{array}{l}\text { Espaço e forma } \\
\text { - conceitos geométricos - O que } \\
\text { permitirá compreender, descrever } \\
\text { e representar, de forma organi- } \\
\text { zada, o mundo em que vive } \\
\text { - Noções geométricas contribuem } \\
\text { para a aprendizagem de números } \\
\text { e medidas, pois estimula a criança } \\
\text { a observar, perceber semelhanças e } \\
\text { diferenças, identificar regularida- } \\
\text { des e vice-versa }\end{array}$ \\
\hline & \begin{tabular}{|l|} 
- Noções de medidas: compri- \\
mentos não convencionais e \\
convencionais, peso, tempo, sis- \\
tema monetário \\
• Operações de adição e subtração, \\
baseadas em problemas simples do \\
contexto de um a dois dígitos \\
• Adição e subtração com grau de \\
dificuldade, relacionado a proble- \\
mas de todos os dias
\end{tabular} & & $\begin{array}{l}\text { Grandezas e medida } \\
\text { - Conceitos relativos ao espaço e } \\
\text { às formas } \\
\text { - Significados dos números e das } \\
\text { operações, da ideia de proporcio- } \\
\text { nalidade e escala }\end{array}$ \\
\hline
\end{tabular}




\begin{tabular}{|c|c|c|c|}
\hline & Bolívia & & Brasil \\
\hline \multirow{10}{*}{ 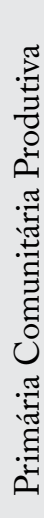 } & - Adição e subtração de números & 요 & Tratamento de informações \\
\hline & naturais no comércio & $\dot{U}$ & - Estatística, organizar, comunicar \\
\hline & - Noções de frações na prática &. & e interpretar dados, utilizando \\
\hline & diária & $\exists$ & tabelas, gráficos e representações \\
\hline & - Figuras geométricas no ambiente: & $\frac{21}{\pi}$ & que aparecem frequentemente em \\
\hline & círculo, triângulo, quadrado, retân- & ت્ّ̇ & seu dia-a-dia \\
\hline & gulo e suas características & $\underline{z}$ & -Combinatória, combinações, \\
\hline & - Medidas de peso do uso diário & $\stackrel{\Xi}{\exists}$ & arranjos, permutações e, especial- \\
\hline & - Forma simbólica, literal e gráfica & 0 & mente, o princípio multiplicativo \\
\hline & de quantidades & & da contagem à probabilidade \\
\hline
\end{tabular}

Fonte: Planificação curricular (Bolívia) 2014 e PCN 1998 (Brasil), elaborado pela autora

Observa-se que o currículo boliviano apresenta os conteúdos de maneira clara e objetiva. Por outro lado, verifica-se que, no currículo brasileiro, prevalece a subjetividade. Podemos também observar que, na disciplina de matemática do currículo boliviano, a noção de cálculos voltados para o trabalho/comércio está contida nos conteúdos desde os anos iniciais.

Quadro 3 - Blocos de disciplinas dos níveis equivalentes ao Ensino Médio - Brasil Primária Comunitária Vocacional - Bolívia

\begin{tabular}{|c|c|c|c|c|c|}
\hline & Área & Bolívia & & Área & Brasil \\
\hline \multirow{4}{*}{ 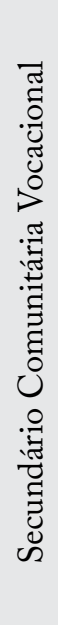 } & \multirow{4}{*}{$\begin{array}{l}\text { Comunidade } \\
\text { e Sociedade }\end{array}$} & \begin{tabular}{|l} 
Comunicação e \\
linguagem: Língua \\
Castellana e \\
originária \\
\end{tabular} & \multirow{4}{*}{ 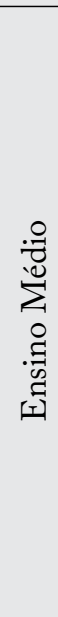 } & \multirow{4}{*}{ Linguagens } & Língua Portuguesa \\
\hline & & Língua extrangeira & & & $\begin{array}{l}\text { Inglês - Língua } \\
\text { Estrangeira } \\
\text { Moderna }\end{array}$ \\
\hline & & Ciências sociais & & & $\begin{array}{l}\text { Espanhol - Língua } \\
\text { Estrangeira } \\
\text { Moderna }\end{array}$ \\
\hline & & $\begin{array}{l}\text { Educação Física e } \\
\text { Esportes }\end{array}$ & & & $\begin{array}{l}\text { Língua Materna } \\
\text { - para População } \\
\text { indígena }\end{array}$ \\
\hline
\end{tabular}




\begin{tabular}{|c|c|c|c|c|c|}
\hline & Área & Bolívia & & Área & Brasil \\
\hline \multirow{10}{*}{ 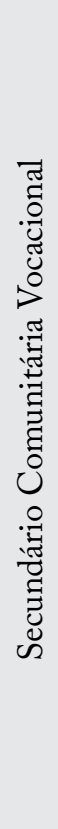 } & \multirow{2}{*}{$\begin{array}{l}\text { Comunidade } \\
\text { e Sociedade }\end{array}$} & Educação Musical & \multirow{7}{*}{ 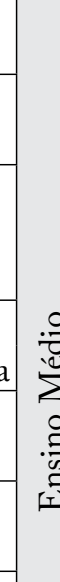 } & \multirow{2}{*}{ Linguagens } & Arte \\
\hline & & $\begin{array}{l}\text { Artes plásticas e } \\
\text { visuais }\end{array}$ & & & Educação Física \\
\hline & $\begin{array}{l}\text { Ciências, } \\
\text { Tecnológica e } \\
\text { Produção } \\
\end{array}$ & Matemática & & Matemática & Matemática \\
\hline & \multirow{4}{*}{$\begin{array}{l}\text { Vida terra } \\
\text { território }\end{array}$} & Ciências naturais: & & \multirow{3}{*}{$\begin{array}{l}\text { Ciências da } \\
\text { Natureza }\end{array}$} & Biologia \\
\hline & & Biologia - Geografia & & & Física \\
\hline & & $\begin{array}{l}\text { Ciências naturais: } \\
\text { Física }\end{array}$ & & & Química \\
\hline & & $\begin{array}{l}\text { Ciências naturais: } \\
\text { Química }\end{array}$ & & \multirow{4}{*}{$\begin{array}{l}\text { Ciências } \\
\text { Humanas }\end{array}$} & História \\
\hline & \multirow{3}{*}{$\begin{array}{l}\text { Cosmos e } \\
\text { Pensamento }\end{array}$} & $\begin{array}{l}\text { Visão de mundo, } \\
\text { filosofia e sociologia }\end{array}$ & & & História (local) \\
\hline & & Valores, & & & Geografia \\
\hline & & $\begin{array}{l}\text { espiritualidade e } \\
\text { religiosidade }\end{array}$ & & & Geografia (local) \\
\hline
\end{tabular}

Fonte: Planificação curricular (Bolívia) 2014 e Resolução CNE/CEB N. 3/1998 (Brasil), adaptado pela autora

O Quadro 3 estabelece o bloco de disciplinas do Ensino Médio e Secundário, no qual podemos observar que no bloco de Linguagem temos a aplicação de línguas estrangeiras nos dois países. Também, no mesmo bloco, está contida na grade boliviana a disciplina de Educação Musical. Nesse sentido, ressaltamos que a matemática está presente no ensino de música, nas utilizações das teorias de conjunto, na álgebra abstrata e na teoria dos números, conforme afirma Ferreira (2010, p.16): "Quando estudamos música, estamos aprendendo as regras dos sons em combinação", o que Pitágoras, Arquitas, Aristóxenes e Erástenes, grandes matemáticos, desenvolviam na antiguidade com as teorias musicais.

\section{$4 \mathrm{O}$ contexto da pesquisa no espaço escolar boliviano}

Os Mapas Mentais como metodologia de pesquisa compõem um significante instrumento para apreensão do mundo vivido representado 
pelos desenhos, referente àquilo que os alunos conhecem do espaço em que está inserido. Nesse contexto, os signos demonstram o que está ao seu redor, as concepções e as percepções reais do mundo apreendido e vivido pelo estudante boliviano para a disciplina de matemática.

4.1 Itinerários metodológicos para a realização da pesquisa

A pesquisa, bibliográfica e de campo, foi desenvolvida em novembro de 2014, com 30 alunos bolivianos do nível secundário, homens e mulheres entre 12 e 17 anos de idade, nas Unidades Educativas da Bolívia, na cidade de Guayaramerín.

$\mathrm{Na}$ coleta e análise dos dados, seguimos a metodologia analítica dos mapas mentais proposta por Kozel (2005), para a qual a metodologia de análise do conteúdo está de acordo com os seguintes requisitos:

1 - Interpretação quanto à forma de representação dos elementos na imagem;

2 - Interpretação quanto à distribuição dos elementos na imagem;

3 - Interpretação quanto à especificidade dos ícones: Representação dos elementos da paisagem natural; Representação dos elementos da paisagem construída; Representação dos elementos móveis; Representação dos elementos humanos.

4 - Apresentação de outros aspectos ou particularidades.

Os sujeitos da pesquisa foram 30 jovens (homens e mulheres), estudantes do nível secundário das escolas bolivianas. A construção dos mapas mentais, com foco em desenvolver um desenho que exemplificasse o que é a escola para esses alunos, foi realizada com duração de 1 h30 (uma hora e trinta minutos); em seguida, foi desenvolvido um diálogo com cada indivíduo, no qual se buscou compreender melhor as particularidade de cada desenho.

Nas representações da escola, para este artigo, buscou-se a perceptiva de identificar nos mapas mentais as contribuições para a formação dos alunos bolivianos e o espaço que a matemática ocupa nas concepções desses alunos. 
4.2 Representação da escola a partir dos mapas mentais produzidos pelos alunos bolivianos

Escola é... O lugar onde se faz amigos

Não se trata só de prédios, salas, quadros,

Programas, horários, conceitos...

Escola é, sobretudo, gente

Gente que trabalha, que estuda,

Que se alegra, que se conhece, que se estima.

(A escola é... Paulo Freire). ${ }^{2}$

A escola, entrelaçada com os agentes socioeducacionais, concerne à capacitação de pessoas para o exercício da cidadania. Nesse aspecto, a importância da escola não se reflete apenas nos conteúdos escolares, mas também nas interações sociais proporcionadas, as quais desempenham papel de grande significância na formação da personalidade. Nesse sentido, Libâneo (2010, p.37) afirma que:

[...] aprender a aprender não é mais que a condição em que o aluno assume conscientemente a construção do conhecimento, aprende como fazê-lo e utiliza os conteúdos internalizados (conceitos, habilidades, atitudes, valores) em problemas e necessidades da vida cotidiana.

De acordo com as concepções do autor, podemos inferir que a escola, hoje, precisa proporcionar respostas educativas e metodológicas em relação às exigências contidas nos contextos da diversidade cultural, conhecendo as interpretações e concepções de seus alunos. Nessa perspectiva, os mapas mentais constituem-se como metodologias das quais emergem as vislumbrações abstratas que os alunos codificam, disponibilizando aos professores, supervisores e pesquisadores, imagens reais e palpáveis sobre a escola.

\footnotetext{
${ }^{2}$ Poesia de autoria de Paulo Freire, disponível no site: Instituto Paulo Freire (http://www. paulofreire.org/)
} 
Nesse contexto, da composição de 30 mapas mentais, foram destacados dois mapas, seguindo as concepções da matemática para os alunos bolivianos. No Mapa 1, podemos analisar a perspectiva de exposição dos objetos no desenho. Ele apresenta desenhos bem definidos em três campos: o primeiro, à esquerda, representa dois alunos que pedem por amor, paz e igualdade a todos; no centro, está o aluno na aula de matemática com o professor explicando; abaixo, está a representação de dois alunos jogando bola.

Figura 1 - Mapa Mental 1 - Escola: matemática, futebol e igualdade.
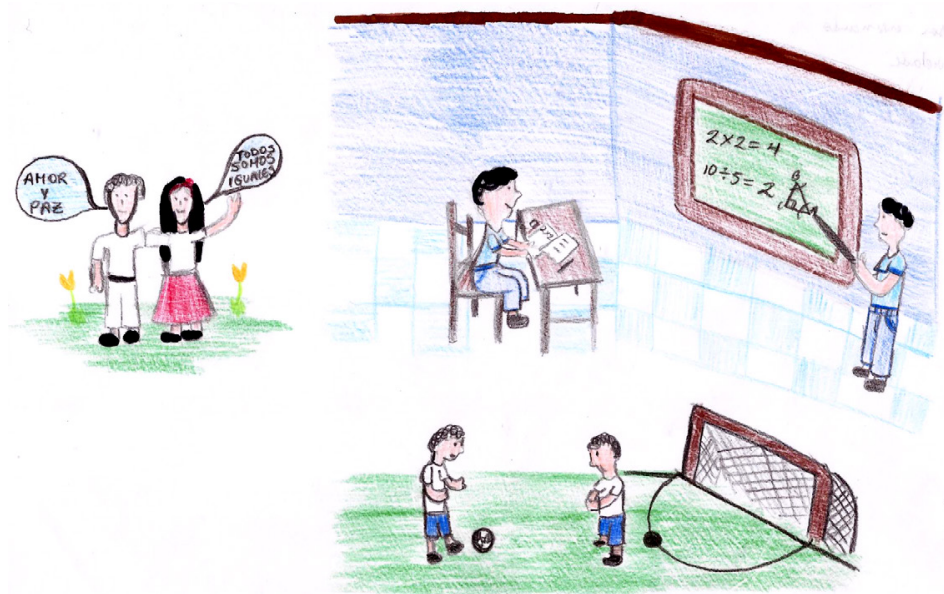

Fonte: Pesquisa de campo, novembro de 2014. Arquivo pessoal GRFS

Podemos refletir sobre o aspecto do espaço físico para chegarmos ao espaço abstrato e inferir que a matemática atrai os alunos bolivianos, visto que o desenho estabelece como a principal atividade desenvolvida por esse aluno, além de o sorriso em seu rosto expressar o gosto pela disciplina. $\mathrm{O}$ professor, em consonância com as teorias de Libâneo, mostra que:

Proporcionar ao aluno uma aprendizagem significativa supõe da parte do professor conhecer e compreender motivações, interesses, necessidades de alunos diferentes entre si, capacidade de comunicação com o mundo do outro, sensibilidade para situar a relação docente no contexto físico, social e cultural do aluno. (LIBÂNEO, 2007, p.44) 
Outro aspecto a ser destacado no desenho é o diálogo entre os alunos, que nos faz refletir sobre o quão importante é o papel da escola, mais precisamente a função do professor na composição da igualdade entre os alunos. Para tanto, cabe respeitar as singularidades existentes em cada indivíduo, observando que “[...] o respeito às diferenças vai mais longe, implica um posicionamento ativo de reconhecer a diversidade que é 'ver em cada indivíduo a presença universal e simultaneamente a do particular." (LIBÂNEO, 2007, p. 77). É nesse contexto que o educador pode construir um caminho harmônico, estabelecendo os elos entre os alunos.

Freire (1996) afirma que devemos trabalhar com as diferenças de modo a reconhecê-las e valorizá-las, para que os educandos possam falar e ser ouvidos. Aos educadores incumbe a tarefa mais importante de conhecer as esperanças, lutas, trajetórias e especificidades culturais que caracterizam os alunos e levar em consideração o respeito presente no senso comum, a fim de estabelecer diálogos pedagógicos mais interculturais, mais reflexivos e menos excludentes.

A Figura 2 apresenta o desenho de uma jovem de 15 anos, que está no terceiro ano da Educação Secundária Comunitária Produtiva. Ela desenhou a escola com o professor de matemática e os alunos assistindo à aula e, no desenho, podemos observar a proporção do espaço para constituição da aula de matemática. Nessa perspectiva, a partir dos elementos contidos no mapa, podemos tecer algumas reflexões:

Figura 2 - Mapa Mental - Escola: matemática
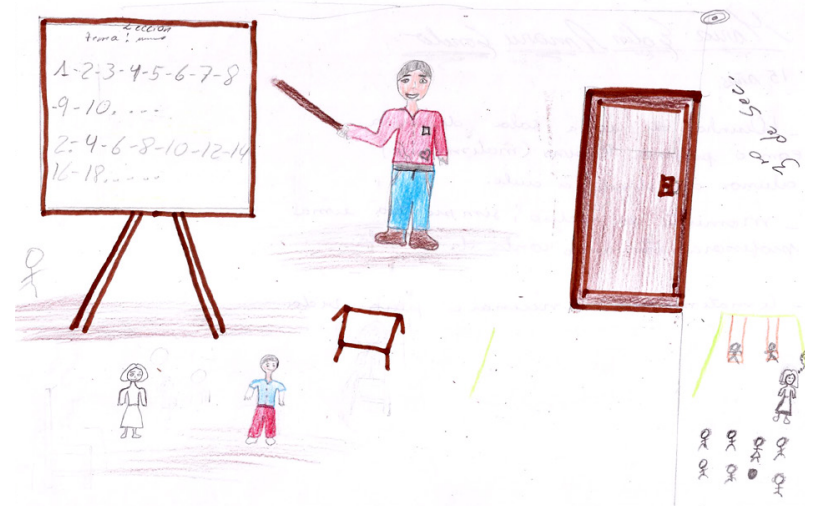

Fonte: Pesquisa de campo, novembro, 2014. Arquivo pessoal GRFS 
A representação da aluna demonstra a aula de matemática e o educador que, ao ensinar, o realiza com alegria. Para Marli (2013), a coisa mais importante que um professor pode almejar é estimular os alunos a se aplicarem ao estudo e, para que isso aconteça, as aulas precisam "ter sabor”, precisam despertar a curiosidade e ter significados para os alunos, preparando-os para o desenvolvimento da cidadania.

As concepções apresentadas pela autora nos remetem à reflexão de que a matemática está relacionada com as necessidades de preparar os indivíduos para viverem como sujeitos ativos na sociedade, por meio de interações com o local no qual habitam. Seguindo essa reflexão, destacamos as ideias de Vygostky (1998), para o qual as interações sociais na perspectiva sócio-histórica permitem pensar um ser humano em constante construção e transformação, mediante as interações sociais e conquistas, as quais conferem novos significados e olhares para a vida em sociedade e para os acordos grupais.

Nesse sentido, podemos afirmar que a matemática nos possibilita alcançar essa finalidade interacionista, envolvidos na situação de ensino construída, e construir situações artificiais, que representam a vivência dos alunos em seus cotidianos. Conforme Godoy (2015, p. 190):

[...] estabelecer as relações entre matemática escolar e as demais áreas do conhecimento e da vida cotidiana não serve para justificar a importância dos saberes matemáticos na educação escolar, mas para desenvolver, entre outras habilidades e competências, o pensamento crítico, a leitura e a interpretação do mundo exterior à escola, com o auxílio do conhecimento matemático.

Outro aspecto mostrado no desenho configura o momento do recreio, em que há crianças estão brincando sob a supervisão de uma professora. Nesse aspecto, tomemos as concepções do brincar para Vygostky (1998), para o qual brincar é um ato social, pois a criança não brinca sozinha: ela tem um brinquedo, um ambiente, uma história, um colega e um professor, que medeia essa relação e que faz do brincar algo criativo e estimulante. A forma como o brincar é mediado no contexto da escola é importante para 
que seja de qualidade e realmente ofereça a oportunidade de diferentes aprendizagens para os alunos. "A memória da criança não somente torna disponível fragmentos do passado como, também, transforma-se num novo método de unir elementos da experiência passada com o presente". (VYGOTSKY, 1998, p.48)

Os aspectos sociais de interação entre os alunos são constituídos de significados, a partir dos quais "A escola precisa deixar de ser meramente uma agência transmissora de informação e transformar-se em um lugar de análise crítica e de produção da informação, onde o conhecimento possibilita a atribuição de significados à informação" (LIBANEO, 2007 p. 26). A escola deve oferecer condições pelas quais as atividades se convertam numa forma particular de entrar em contato com a cultura, em um ambiente que proporciona essa inter-relação cultural.

\section{Considerações finais}

A escola tem um papel único na reprodução das sociedades humanas e na previsão das condições que possibilitam a inovação e as mudanças, por isso, a representação da escola pelos alunos bolivianos tem suma importância para continuarmos a discutir o papel da escola na educação.

Nesse contexto, o professor se constitui como a mola propulsora que motiva seus alunos ao aprendizado, com isso, a natureza do ensino exige que o professor esteja "aprendente" e docente, ou seja, conforme Libâneo (2007) e Feire (1996), a docência é uma profissão que se aprende pela vivência da docência. $\mathrm{O}$ educador, nesse sentido, desempenha o seu papel no processo de despertar no aluno o gosto pelo aprendizado, o que foi observado pela análise dos mapas mentais.

$\mathrm{O}$ uso de mapas mentais como recurso didático auxilia o educador na representação que o educando faz sobre o mundo ao seu redor, possibilitando ao professor maior compreensão na construção das concepções do ato de ensinar e de aprender. Nesta pesquisa sobre o contexto educacional boliviano, ficou nítido que a reflexão da Educação Matemática constituirá subsídios para a formação dos professores e que as representações dos 
mapas mentais materializam a concepções e o gosto pela matemática. Dessa forma, pela comparação feita entre a educação boliviana e a educação brasileira, podemos afirmar que os alunos bolivianos apreciam com maior satisfação a disciplina de matemática. Nesse sentido, verificamos que o professor boliviano tece um emaranhado de concepções, por meio de sua metodologia.

O maior desafio do futuro próximo será, muito possivelmente, o de encontrar formas eficazes de articular a criatividade dos professores na construção de situações e materiais adequados aos seus alunos, com os imperativos sociais de uma formação de base sólida para todos os alunos.

Com isso, os mapas mentais demonstraram como as representações compõem o fazer pedagógico, ou seja, a atuação do profissional emerge sob o olhar dos alunos, o que permite refletir sobre o espaço vivido e representado em diversas nuances, cujos signos são construídos por meio de ações sociais e os estudantes são os sujeitos que as refletem.

Ressaltamos que os mapas mentais construídos pelos alunos oferecem subsídios para desenvolver metodologias concretas, já que esses mapas exprimem - em uma linguagem carregada de significados, refletindo o espaço vivido - as concepções, os gostos e as experiências desenvolvidas ao longo de toda a sua trajetória escolar.

Todavia, todo o esforço aplicado neste trabalho considera proporcionar um caminho de diálogos e discussões teóricas que aguçam a necessidade do aprofundamento das questões referentes à pesquisa do potencial do mapa mental como recurso didático para a aprendizagem de alunos em todos os níveis.

\section{Referências}

BOLÍVIA. Educación secundaria comunitária produtiva. La Paz: Ministerio de Educacion, 2012.

BOLÍVIA. Estrategias de desarrollo curricular socio-productivo: compreendendo la estrutura curricular. La Paz: Ministerio de Educacion, 2014.

BOLÍVIA. Ley de la Educación no 070: “Avelino Siñani - Elizardo Perez”. La Paz: Ministerio de Educacion, 2010. 
BRASIL, Lei de Diretrizes e Base da Educação Nacional. Lei no 9.394/96, de 20 de dezembro de 1996.

BRASIL, Ministério da Educação e do Desporto, Secretaria de Educação Fundamental. Parâmetros curriculares nacionais. Brasília: MEC/SEF, 1998.

BRASIL. Ministério da Educação. Conselho Nacional de Educação. Câmara de Educação Básica. Parecer CEB no 5/2011, de 5 de maio de 2011. Diretrizes Curriculares Nacionais para o Ensino Médio. Diário Oficial da União. Brasília, DF, 24 jan. 2012

BRASIL. Secretaria de Educação Básica. Orientações Curriculares do Ensino Médio. Brasília: MEC/SEB, 2004.

FERREIRA, Martins. Como usar a música na sala de aula. São Paulo: Contexto, 2010.

FREIRE, Paulo. Pedagogia da autonomia: saberes necessários à prática educativa. São Paulo: Paz e Terra, 1996.

GODY, Elenilton Vieira. Currículo, cultura e educação matemática: uma aproximação possível? Campinas, São Paulo: Papirus 201

PIAGET, Jean. Para onde vai a educação? Rio de Janeiro: Livraria José Olympo Editora/ Unesco, 1973.

KOZEL, Salete. Mapas mentais - uma forma de linguagem: Perspectivas metodológicas. In: KOZEL S. et al. (Org.): Da percepção e cognição à representação. São Paulo: Terceira Margem, 2007. p.114-138.

KOZEL, Salete. Resinificando as representações do espaço: as linguagens do cotidiano. In: ENCONTRO DE GEOGRÁFICOS DA AMÉRICA LATINA, 10, 2005, São Paulo. Anais.... 2005. p. 7283-7296. Disponível em: <http://observatoriogeograficoamericalatina. org.mx/egal10/Geografiasocioeconomica/Geografiaespacial/14.pdf $\rangle$

KOZEL, Salete (Org.). Mapas Mentais: Dialogismo e representações. Curitiba: Appris, 2018.

LIBÂNEO, José Carlos. Adeus professor, adeus professora? Novas exigências educacionais e profissão docente. São Paulo: Cortez, 2007

MALI, Taylor. Um bom professor faz toda a diferença. Rio de Janeiro: Sextante, 2013

RICHTER, Denis. O mapa mental no ensino de geografia: concepções propostas para o trabalho docente. São Paulo: Cultura Acadêmica, 2011.

WANNER, Maria Celeste de Almeida. Paisagens sígnicas: uma reflexão sobre as artes visuais contemporâneas. Salvador: EDUFBA, 2010.

VYGOTSKY. L. S. A formação social da mente. São Paulo: Martins Fontes, 1998. 


\section{A PERCEPÇ̃̃O DA ESCOLA PELO ALUNO ATRAVÉS DُOS MAPAS MENTAIS: VISANDO A SUPERAÇÕES E OPORTUNIDADES}

Glauciane Sanches da Silva

Rosenete Salvatierra Marinho Niederauer²

Elaine Márcia Souza Rosa ${ }^{3}$

\section{Introdução}

Os mapas mentais aqui analisados são partes dos mapas aplicados do Projeto "Geopedagogia: a escola e mapas mentais de alunos brasileiros, haitianos e bolivianos, vinculado ao Programa Institucional de Pesquisa do Instituto Federal de Educação, Ciência e Tecnologia do Estado de Rondônia (IFRO)" (1), no ano de 2014, destacados e desenvolvidos pelos alunos da Escola Estadual de Ensino Fundamental e Médio Simon Bolivar, localizada no município de Guajará-Mirim/RO. Nessa escola, foram aplicados 21 mapas mentais, em alunos do $8 .^{\circ}$ ano do Ensino Fundamental ao $2 .^{\circ}$ ano do Ensino Médio, com faixa etária de 14 a 17 anos, sendo $62 \%$ do sexo feminino e $38 \%$ do sexo masculino.

A perspectiva primeira deste estudo baseou-se na identificação do que é a escola para os alunos, como ele a vê, qual o seu significado e impacto na vida, com o intuito de captar essa informação de forma espontânea e fidedigna, sem precisar de o aluno expressar-se oralmente. Para

\footnotetext{
${ }^{1}$ Acadêmica do Curso de Licenciatura em Pedagogia - 4. ${ }^{\circ}$ período pela Universidade Federal de Rondônia. E-mail: glaucianesanches@hotmail.com.

${ }^{2}$ Acadêmica do Curso de Licenciatura em Pedagogia - 4. ${ }^{\circ}$ período pela Universidade Federal de Rondônia. E-mail: rosenete.niederauer@gmail.com.

${ }^{3}$ Pedagoga pela Universidade Luterana do Brasil - ULBRA. Especialista em Supervisão, Orientação e Gestão Escolar pela Faculdade Santo André - FASA. Professional of Life Coaching pela Sociedade Latino Americana de Coaching - SLAC. Pesquisadora do Grupo de Pesquisa em Educação, Filosofia e Tecnologias GET/IFRO. Assistente de Alunos do Instituto Federal de Rondônia - Reitoria. Email: elaine.marcia@ifro.edu.br.
} 
tanto, os campos da Geografia Cultural deram sustentáculos às investigações; assim utilizou-se o Método dos Mapas Mentais da pesquisadora Dra. Salete Kozel, orientados pela Teoria das Representações Sociais de Serge Moscovici (2).

Para aplicação dessa metodologia, os alunos foram convidados a expressar, utilizando-se de desenhos, a pergunta norteadora: $\mathrm{O}$ que é a escola para você?, recebendo os materiais necessários para confecção dos desenhos. Após o desenvolvimento dessa atividade, os pesquisadores questionaram os alunos em relação ao significado dos desenhos e registraram suas respostas. Essas anotações serão consideradas na análise geral dos mapas.

As análises realizadas pelos pesquisadores, perante a visão panorâmica dos alunos por meio dos mapas mentais sobre a escola, nortearam esta pesquisa qualitativa no progresso deste recurso aplicado, que contribui para o desenvolvimento de aprendizagem. Trata-se de uma técnica simples, significativa e transformadora no auxílio escolar, pois observar, por seu intermédio, o que a escola representa para suas vidas, destacando, inclusive, os mapas que, em sua maioria, afirmam ser esta sua segunda casa e um lugar para se conquistar oportunidades.

\section{História e cultura}

Guajará-Mirim, está localizada no interior do Estado de Rondônia, na região norte do país. Foi criada no dia 12 de julho de 1928 e, conforme o Instituto Brasileiro de Geografia e Estatística, a "população estimada", no ano de 2018, "gira em torno de 45.783" (3) habitantes. Esta cidade faz fronteira com a Bolívia, separada pelo rio Mamoré, o que propicia o turismo local e também o comércio internacional.

Dois importantes marcos da história favoreceram a formação do povoado desta localidade, a saber: o primeiro e segundo ciclo da borracha, que viabilizou a migração de pessoal sobretudo da região nordeste, motivados pela perspectiva de viver uma vida melhor, longe da seca e da pobreza que assolava a região. Este evento impulsionou avanços significativos para o desenvolvimento do atual estado de Rondônia, visto que 
foram criadas as linhas telegráficas para integração da comunicação com as demais regiões desenvolvidas do país e foi constituído o transporte ferroviário no ano de 1907 a 1912, porém, desativado em 1972. Trata-se da Estrada de Ferro Madeira-Mamoré, que, por sua vez, fazia a ligação da Capital do Estado, Porto Velho, a Guajará- Mirim, com o objetivo primeiro de fazer o escoamento da borracha. A ferrovia foi de suma importância, pois trouxe visibilidade ao país, e assim fomentava o povoamento da comunidade. Consequentemente, esse fato contribuiu para a miscigenação de povos, sobretudo os das tribos indígenas e dos bolivianos, em decorrência de sua fronteira com a Bolívia.

A economia baseia-se em extrativismo vegetal, com a atividade madeireira, e o extrativismo florestal, com a extração de látex e drogas do sertão. Os ramos agrícola e pecuária podem ser considerados principiantes, visto ter a cidade $93 \%$ de reservas ambientais protegidas por lei, e, portanto, não se pode expandir numerosas áreas de desmate para a prática dessas atividades. Assim, a principal estrutura econômica ainda é o funcionalismo público e agricultura familiar. Na cultura, o folclore possui forte influência dos indígenas, com o festival dos bois Malhadinho e Flor do Campo e, na culinária, são bem marcantes as iguarias: vatapá, saltenha, bolo de macaxeira e tacacá (4).

\section{Organização do sistema escolar do país / município / departamento onde foram aplicados os mapas}

De acordo com a Constituição Federal de 1988, o sistema educacional brasileiro é regido pelas Leis n ${ }^{\circ} 9394$, de 1996, e pela Constituição de 1988, as quais estão em atividade, como Lei maior que regulamenta tal sistema. A estrutura de educação á assim organizada: educação básica (realizada em creches, até 3 anos); infantil (pré-escola de 4-6 anos); ensino fundamental (duração de nove anos), segundo a Lei 11.274 de 06/02/2006, sendo obrigatória e gratuita na escola pública, dando garantia de educação a todos; o médio (com duração de 3 anos) dá, ao educando, formação geral; há ainda o ensino regular, para portadores de necessi- 
dades especiais, e a educação de jovens e adultos, incluindo também o ensino de nível técnico, bem como a educação superior. Estabelece-se, assim, o sistema educacional, para o qual a Lei n 9.394/96 garante acesso democrático para todos, oferecendo definições políticas e mudanças significativas na educação básica do Brasil.

Em conformidade com as Leis federais, no que se refere ao Sistema Estadual de Ensino de Rondônia, destaca-se que, tanto o estado, bem como os municípios, conforme o artigo 188, da Constituição Estadual, são responsáveis e têm autonomia em organizar, de forma participativa, seus sistemas de ensino. Esse sistema estadual está assim organizado: 1- Rede de escolas: estaduais; municipais; privadas; 2 - Estrutura de Sustentação: Secretaria de Estado de Educação, Secretarias Municipais de Educação. O sistema municipal de Guajará-Mirim/RO, por sua vez, dispõe de suas aptidões e incumbências para o desenvolvimento da educação escolar. Criado em 10 de janeiro de 2007, pela Lei Municipal n 1178/08, compreende as escolas Municipais de Educação Infantil e de Ensino Fundamental; as Instituições de Educação Infantil Privada; a Secretaria Municipal de Educação (SEMED); O Conselho Municipal de Educação (CME), criado oficialmente no dia 15 de fevereiro de 2007, valendo-se da Lei Municipal n ${ }^{\circ} 1.177-$ GAB/PREF/07, sendo modificada pela Lei n 1.725 /GAB/ PREF/ 14.

Ademais, no município de Guajará-Mirim, destaca-se a Escola Estadual de Ensino Fundamental e Médio Simon Bolívar (EEEFM), onde foram aplicados os mapas mentais em 2014 (objetivo principal desta pesquisa), a qual, hoje, é a primeira escola em Guajará-Mirim, a funcionar o sistema de Ensino Integral. A escola foi fundada em 1950, sendo o terceiro estabelecimento de educação, objeto de estudo das fontes documentais. Localizada em área urbana, possui transporte escolar público, com modalidade regular fundamental e médio, e sua infraestrutura possui: biblioteca, laboratório de informática, laboratório de ciências, quadra de esporte, dispõe de internet, com banda larga, e 23 computadores acessíveis aos alunos.

Dessa forma, as organizações de cada conjuntura escolar, seja nos estados seja nos municípios, opera de acordo com as necessidades da região e, em consonância, com as Leis federais, estando acessível a múltiplas 
tendências educacionais, para que haja progresso e desenvolvimento qualitativo dos alunos.

\section{Análise dos mapas}

Os mapas geográficos trazem o norteamento necessário para a obtenção do resultado que se quer encontrar. Ao analisar esse segmento, o objetivo primeiro é conhecer e situar-se em determinada localidade em que se pretende atuar. Analogicamente, os mapas mentais, através da geografia humanista, possui esse objetivo, observando, portanto, o olhar do sujeito e do pesquisador. Com essa ferramenta, é possível extrair do indivíduo as ideias e perspectivas, e isto é evidenciado por signos, pois "O foco está no sentido que o sujeito apreende as coisas, assim, as imagens a princípio se formam na consciência individual e posteriormente podem ser representadas por meio de signos formando uma imagem" (5), e esses podem ser externados nos desenhos realizados no papel pela pessoa.

Identifica-se, nessas imagens, a personalidade, o que a criança está sentindo ou vivendo no contexto histórico, social e cultural, sendo o método pelo qual o indivíduo expõe as indagações que lhes são propostas por figuras, sinais, escrita, sejam internas ou externas, consciente ou inconscientemente, as experiências vividas, seu eu, os relacionamentos, a percepção de tudo que está ao seu redor, assim “ [...] como uma forma de linguagem referendada no sistema de relações onde estão imbricados valores, sentimentos, atitudes e vivências e essas imagens passam a ser entendidas como mapas mentais." (6), em que as influências e valores estão incidindo sobre esse sujeito, bem como as suas motivações e proposições acerca de determinado assunto, conforme sua singularidade.

Para o pesquisador, hipoteticamente, podem ser realizadas análises dos mapas, subsidiadas pela metodologia aplicada, respaldadas, sobretudo, nos estudos teóricos condizentes do mapa mental, para assim não incorrer no senso comum propriamente da subjetividade de cada investigador. "[...] o processo de construção ou decodificação de uma imagem passa por diferentes filtros e linguagens, particulares de cada indivíduo, que estabelece 
seus códigos de acordo com sua visão de mundo" (7). A propósito, a estes são proporcionados riquezas de conhecimento, aprendizado pelo outro, adquiridos pela leitura realizada.

Uma outra peculiaridade dos mapas mentais é que eles contribuem para a cognição durante sua execução, sem deixar de mencionar o diálogo, o qual é de suma importância nesse processo e que raramente existe nos âmbitos familiar, escolar ou social. Não obstante, pode ser encontrado dentro das expressões aplicadas nas ilustrações realizadas pelo sujeito, como forma de buscar ser compreendido, visto e valorizado.

Á vista disso, utilizam-se métodos sistematizados de análises práticas, ao permearem os mapas. Essa metodologia é baseada em quesitos criados por Salete Kozel, sob diferentes enfoques, considerando a complexidade existente em alguns aspectos, pois esses direcionam o pesquisador a extrair de forma eficiente cada detalhe da produção do indivíduo nos signos. Os elementos intrínsecos ao sujeito possuem variados aspectos a serem observados do mundo vivido. A saber, os quesitos idealizados pela autora são:

1 - Interpretação quanto à forma de representação dos elementos na imagem;

2 - Interpretação quanto à distribuição dos elementos na imagem;

3 - Interpretação quanto à especificidade dos ícones:

- Representação dos elementos da paisagem natural

- Representação dos elementos da paisagem construída

- Representação dos elementos móveis

- Representação dos elementos humanos

4 - Apresentação de outros aspectos ou particularidades (8).

Essa proposta desvela contextos inerentes da pessoa a ser pesquisada, sem a necessidade de o indivíduo evidenciar a comunicação mediante a oralidade e o que está sendo questionado; nesse sentido, o investigador capta as percepções dessas representações e os significados do universo interior e exterior, anteriormente encoberto. Observando as características de como o desenho foi projetado no papel e quais indicadores estão sendo sinalizados, inclusive é possível detectar as influências advindas da cultura, 
que certamente aparecerão na figura. Dessa forma, os mapas mentais viabilizam os encontros entre sujeito e pesquisadores, para uma abertura de relações transformadoras.

\subsection{Descrição dos elementos de análise}

Embora este artigo trate da análise de uma pequena amostragem dos mapas, faz-se necessária a exposição dos 21 trabalhos desenvolvidos na cidade de Guajará-Mirim/RO. Foi no decorrer da pré-análise desses mapas que ficou claro o significado da escola para os alunos, assim como as similaridades representadas, que incorporam "[...] os fatos cotidianos do mundo mais proximamente vivido como fatos a serem amplamente compreendidos, relacionados entre si [...]" (9), que é o enxergar a escola como uma segunda casa, uma porta aberta para um futuro melhor.

Figura 1 - Mapa 1

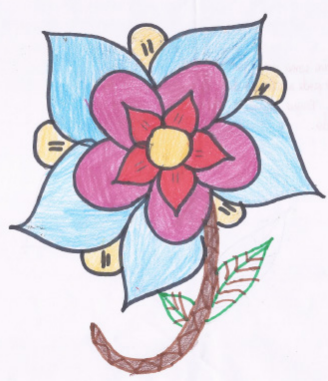

Figura 3 - Mapa 3

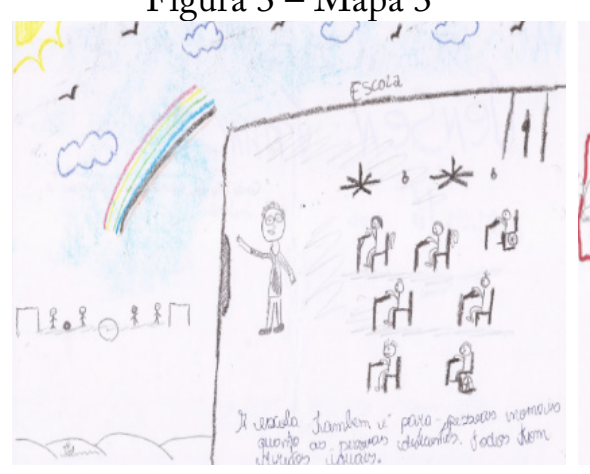

Figura 2-Mapa 2

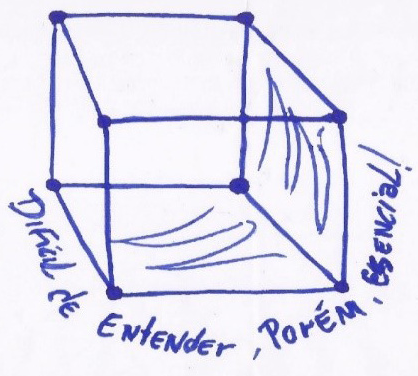

Figura 4-Mapa 4

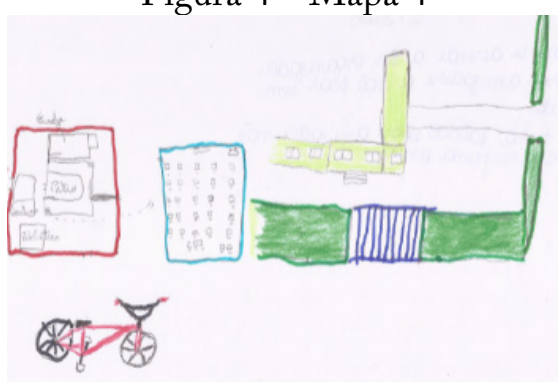


Figura 5 - Mapa 5

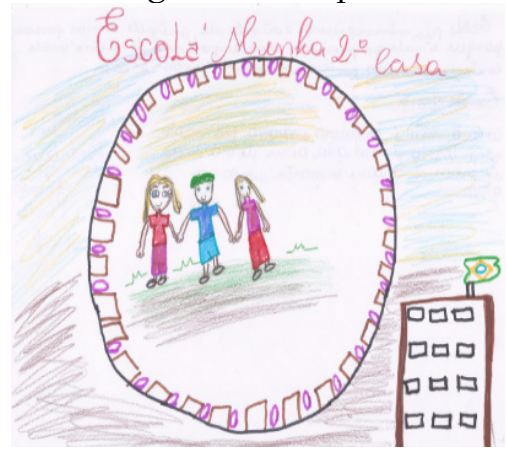

Figura 7 - Mapa 7

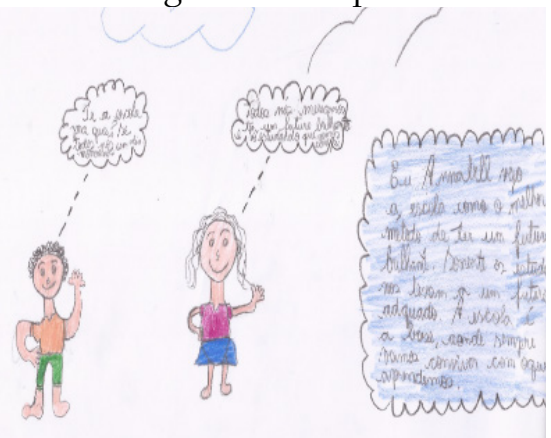

Figura 9-Mapa 9

UNIÃ́O + AMOR+EDUCACÃO $=6 x d a$ !

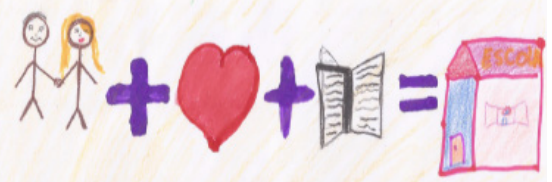

Figura 6-Mapa 6

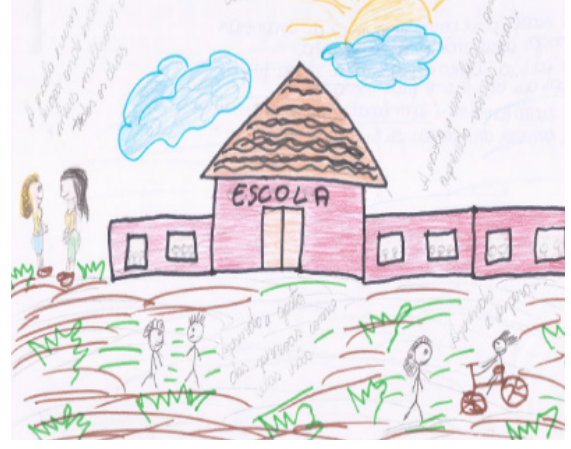

Figura 8-Mapa 8

$\checkmark$ que a a uscola para.

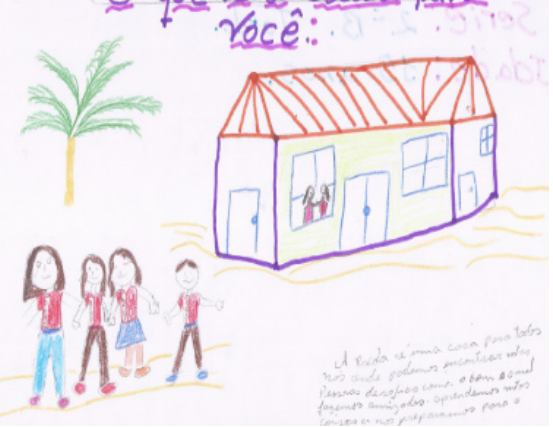

Figura 10 - Mapa 10

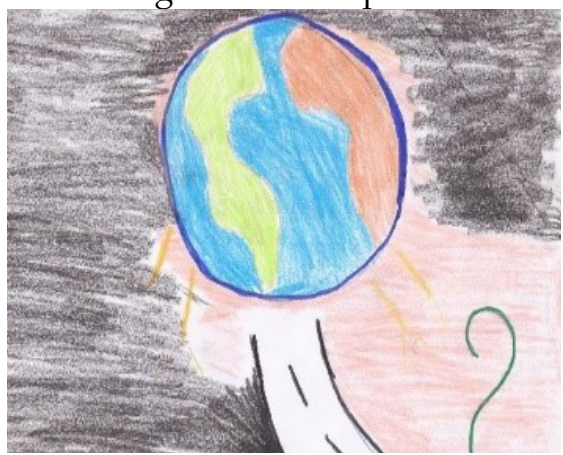


Figura 11 - Mapa 11

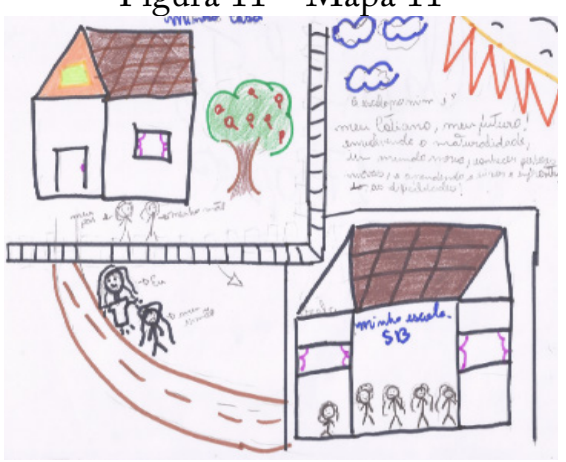

Figura 13 - Mapa 13

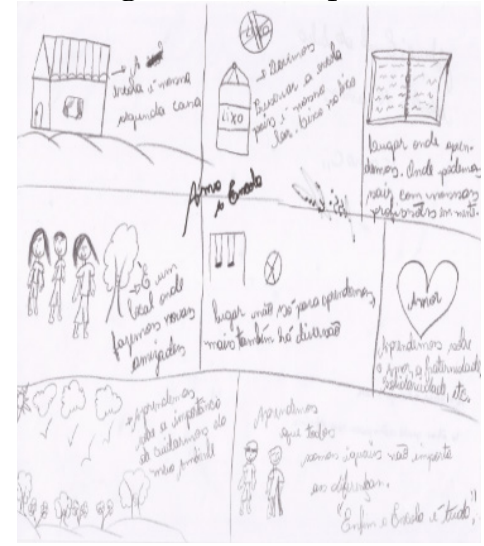

Figura 15 - Mapa 15

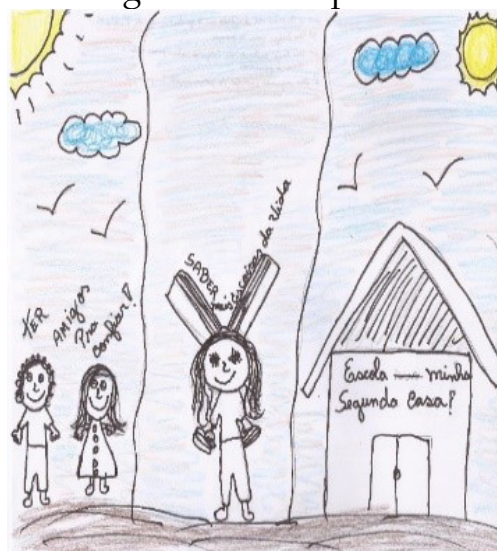

Figura 12 - Mapa 12

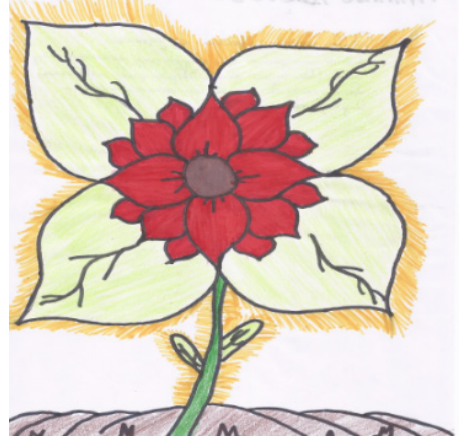

Figura 14 - Mapa 14

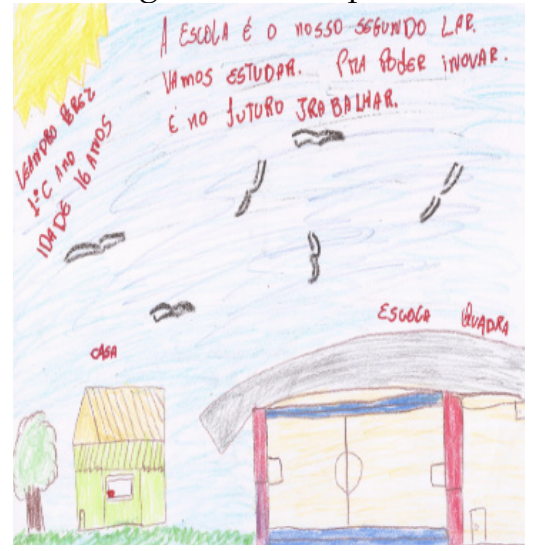

Figura 16 - Mapa 16

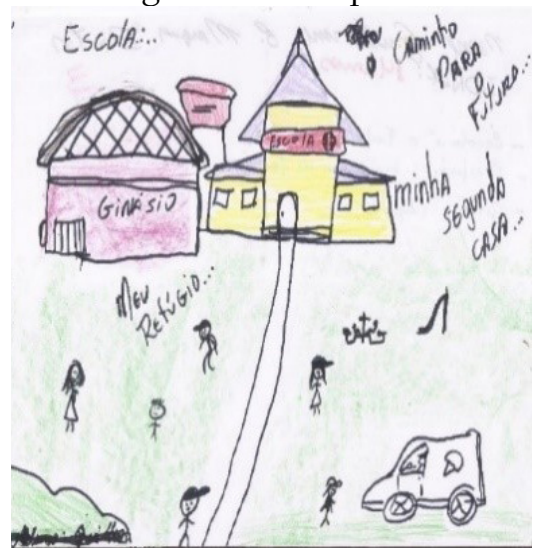


Figura 17 - Mapa 17

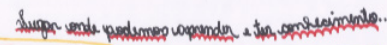

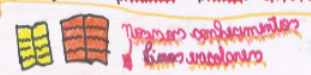

国用

요

Gnoda emintia Vida:

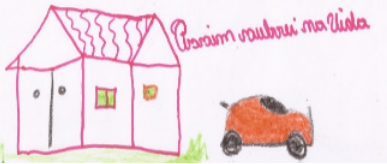

Figura 19 - Mapa 19

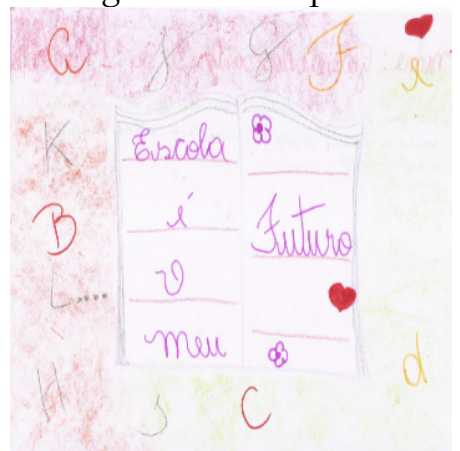

Figura 18 - Mapa 18

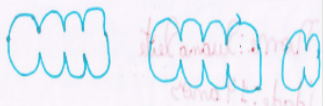

Ciescula pra mim sía minha 2 casa i squ que en aprendo coirsas nevoas.

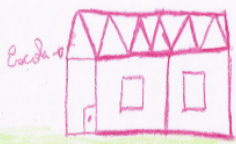

Figura 20 - Mapa 20

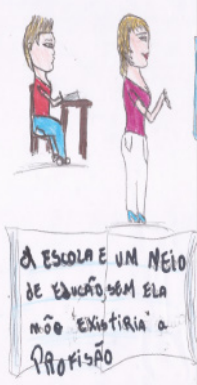

Figura 21 - Mapa 21

LOCal de aprendizado
ESCOLA Caminho
PARa um Futuro melhor
Minha SEgunda CASA


Apresenta-se, a seguir, uma interpretação sucinta dos mapas mentais, obedecendo os quesitos orientados por Salete Kozel:

4.1.1 Quesito 1 - interpretação quanto à forma de representação dos elementos na imagem

Dos vinte e um mapas mentais, onze são representados por ícone de desenho e complementação com palavras (fig. 2, 3, 6, 7, 8, 12, 3, 15, 17, 18, 20); cinco são representados de ícone desenho, complementação com palavras e representação de espacialização do fenômeno escola fFig. 4, 5, 10,11, e 16); um representado por letras soltas, palavras e ícone de desenho (fig. 19); dois são representados por palavras e complemento de ícone de desenho fFig. 9 e 21); e três são representados por apenas ícone desenho fFig. 1, 4 e 12).

Foi possível identificar que, na maior parte das figuras, foram representadas por combinações de ícones de desenhos, de letras formando palavras e frases, e, em algumas delas, as letras e frases fazem a complementação à imagem, e, em outras, as palavras fazem a complementação; e também houve aqueles em que não foram adicionados complementos de palavras na mesma lauda em que o desenho foi realizado.

Nomeando figuras: as frases mais constantes foram "a escola é minha $2^{\circ}$ casa" figuras $(5,6,13,15,16,18) ;$ "a escola é uma casa para todos nós [...]; “ figura (8); "a escola é meu segundo lar.” figura (14), "escola e minha vida", figura (17).

Identificando o lugar representado: representação do espaço físico da escola, seu formato, os espaços internos como a sala de aula, os espaços externos: o campinho de futebol, a quadra de esportes, o pátio da escola, a visão panorâmica de cima, de como a escola está projetada, o trajeto da casa, até a chegada à escola, figuras $(3,4,5,6,8,9,11,13,14,15,16,17$ e 18).

Descrevendo as expressões dos mapas, mantendo o linguajar próprio dos sujeitos, sem correção gramatical: "difícil é entender, porém, essencial!", fig. (2); "a escola também é para pessoas normais quanto as pessoas deficientes. Todos tem diretos iguais", fig. (3); "A escola e um lugar onde 
encontro meus melhores amigos todos os dias, a escola e um lugar onde aprendo várias coisas", fig. (6); "Eu Anabell vejo a escola como o melhor método de ter um futuro brilhante. Somente os estudos nos levam a um futuro adquado. A escola é a base, aonde sempre vamos conviver com o que aprendemos", fig. (7); "A escola é uma casa para todos nós onde podemos encontrar mtos pessoas desafios como o bom e o mal fazemos amizades. Aprendemos mts coisas a nos prepararmos para o nosso futuro”, fig. (8); “União + amor + educação = Escola! Fig. (9); “ a escola pra mim é? Meu cotidiano, meu futuro! Envolvendo a naturalidade, um mundo novo, conhecer pessoas novas, e aprendendo a vive e enfrentar as dificuldades", fig. (11); "lugar não só para aprendermos mais também há diversão" (13); "A escola é o nosso segundo lar. Vamos estudar. Pra poder inovar e no futuro trabalhar", fig. (14); "ter amigos pra confiar! Saber mais as coisas da vida", fig. (15); "meu refúgio... caminho para o futuro... minha segunda casa...", fig. (16); "lugar onde podemos aprender e ter conhecimento... Nossos conhecimentos livros escolares. Assim subirei na vida", fig. (17); "a escola pra mim é a minha $2^{\circ}$ casa. É aqui que eu aprendo coisas novas.”, fig. (18); escola é o meu futuro",fig. (19); “a escola e um meio de educação sem Ela não existiria a profisão", fig. (20); "local de aprendizado escola caminho para um futuro melhor minha segunda casa”, fig. (21).

Formando pequenos textos: majoritariamente as representações retratam o carinho e amor pela escola, externalizado pela escrita, complementando os símbolos que demonstram satisfação.

As mensagens transmitidas pelos desenhos foram complementadas por textos, tornando bem evidente o seu ponto de vista acerca da indagação do que é a escola para eles.

\subsubsection{Quesito 2 - interpretação quanto à distribuição dos elementos na imagem}

Em perspectiva: fig. 1, 2, 8, 11, 12, 13, 14, 15, 16 e 20; Vista aérea: fig. 2, 3, 4, 5, 10 e 16; Forma horizontal: fig. 4, 6, 7, 9, 13, 14, 15, 16, 18 e 21; Maneira dispersa: fig. 3, 11, 13, 14, 16, 17 e 19. 
4.1.3 Quesito 3 - interpretação quanto à especificidade dos ícones - Representação dos elementos: da paisagem natural; da paisagem construída; móveis e humanos.

Constata-se, nos 21 mapas aplicados e mostrados, que, na percepção da escola pelo aluno, "a paisagem não é somente uma porção física do espaço, é um conjunto de signos do passado e presente, que interagem de acordo daquele que a observa." (10). No Quesito 3, a representação dos elementos das paisagens naturais como flores, nuvem, pássaros, sol, arco-íris, solo, lago, água e pato, grama, árvore e céu, estão identificados nos seguintes mapas (fig. 1, 3, 5, 6, 7, 8, 10, 11, 12, 13, 14, 15,16, 17, 18).

Os elementos da paisagem construída manifestam-se no contexto de salas de aula, escolas, muro, portões, biblioteca, pátio, cantina, quadras, escada, corredores, prédios, janelas, portas, casas, caminho, parques, ginásio, caixa d'água... (fig. 3, 4, 5, 6, 8, 9, 10, 11, 13, 14, 15, 16, 17, 18, 21). Nos elementos móveis, observam-se bicicletas e carros nas figuras 3, 6,16 e 17 .

É relevante retratar os elementos humanos deste quesito, pois são as peças fundamentais para a realização da pesquisa, e neles encontramos os alunos, os quais contribuíram para a produção deste estudo, considerando seus desenhos, e, também, professores, pessoas, sem deixar de mencionar o motorista do carro (fig. 3, 5, 6, 7, 8, 9, 11, 13, 15, 16, 20).

\subsubsection{Quesito 4 - apresentação de outros aspectos ou particularidades}

A cidade de Guajará-Mirim é um "[...] município pequeno e tem sua economia baseada no funcionalismo público estadual e federal, turismo e pecuária" (11), apresentando, por isso, poucas oportunidades de trabalho. Diante disso, é possível destacar, em todos os mapas, ícones que representam os principais grupos temáticos, pelos quais a escola é vista como uma oportunidade de mudança, caminho para um futuro melhor; uma segunda casa, onde gosta de estar, como um refúgio; um local de constante aprender, lugar de união, amor e educação; um ambiente de aprendizagem, diversão e inclusão, lugar onde se faz novas amizades. 


\section{Análise fundamentada das temáticas subjacentes aos mapas}

Com a análise prévia de todos os mapas mentais aplicados, foi possível observar diversas afinidades no que tange à expressão de cada um, à semelhança dos desenhos e dos escritos explicitados por meio de frases afetivas, e até insatisfação, sentimento encoberto por entre as ilustrações demonstradas. As informações adicionais coletadas pelas pesquisadoras, no processo de aplicação dos mapas mentais, foram correlacionadas à análise exposta anteriormente, facilitando o entendimento quanto à interpretação dos mapas em relação ao significado da escola para o grupo de alunos envolvidos no processo.

Partindo desse olhar, foram selecionados quatro, dos vinte e um mapas mentais, para serem analisados:

5.1 Figura 2 - Mapa mental 2 - menino / 15 anos

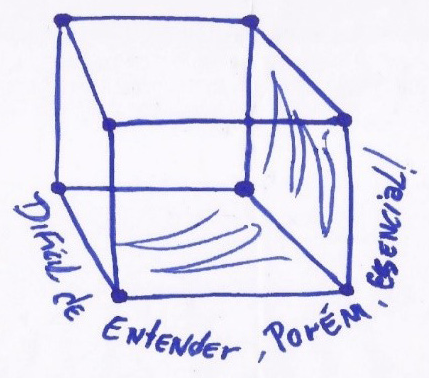

- O aluno retratou um único elemento, sendo um cubo em 3D, transparente, com eixos destacados, tendo a interpretação quanto à distribuição de imagem com representação em perspectiva.

- Em relação à interpretação quanto à forma de representação dos elementos na imagem, apresenta complementação, tendo utilizado representação das palavras "difícil de entender, porém, essencial!", dispostas em forma de "U" na base da figura.

- Em relação à interpretação quanto às especificidades dos ícones da paisagem natural, construída, móveis ou humanas, o aluno não retratou elementos humanos, nem paisagem construída que 
evidenciassem a presença da escola. Contudo, em anotações complementares à representação gráfica, no verso da figura, o aluno explica que: 'Escolbi esta imagem porque ela significa 'algo' complicado, assim como a escola, mas ela nos dá uma oportunidade de cada um ver a entrada, assim como a saida. No inicio pode parecer difícil, mas com um pouco de esforço é possivel, assim como a escola. Todos podem!"

- Esta figura representa a amplitude do significado da escola para o aluno, como um espaço que oferece oportunidades para todas as pessoas, embora em meio a dificuldades da transmissão e assimilação do saber, expressada por ele através da frase "[...] significa 'algo' complicado, assim como a escola[...]", é possível a superação. Assim, as oportunidades podem ser mais bem aproveitadas com o esforço de cada um.

\subsection{Figura 10 - Mapa mental 10 - menino / 16 anos}

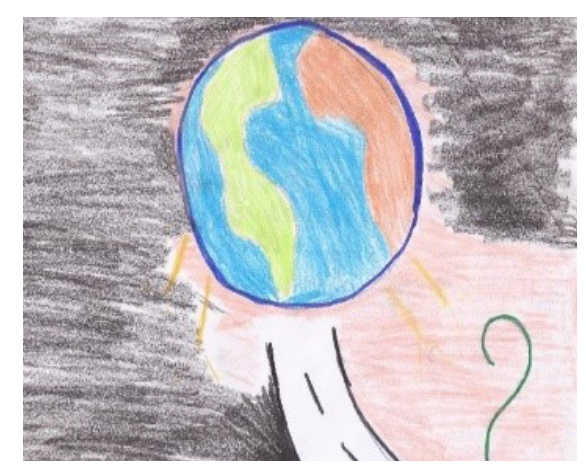

- Neste mapa, podemos observar a figura do planeta terra, representado em vista aérea e destacado em cores fortes, tendo riscos em um tom de dourado em sua base, como se fossem raios luminosos. Da frente do planeta, surge um caminho, que vai ao encontro de um ponto de interrogação. Por volta do planeta e na parte superior direita do caminho, está pintado de rosa claro, e o restante de todo o papel, em volta do desenho, está pintado de preto. 
- Quanto às especificidades dos ícones da paisagem natural, construída, móveis ou humanas, pode ser observada a paisagem natural, sendo o azul e o verde do planeta, a paisagem construída, evidenciada pela estrada asfaltada.

- Em texto complementar, no verso do desenho, o aluno expõe que: "A escola nada mais é que o caminho para o mundo de conhecimento aonde nos encontramos no turbilhão de dúvidas e da incerteza, e por isso precisamos desvendar um caminho entre as coisas boas e ruins em nossas vidas, fazendo então encontrar o mundo de conhecimentos absorvendo aprendizados e liçóes para a vida."

- Mais uma vez fica evidenciado neste mapa a visão da escola pelo aluno, como um ambiente de aprendizagem, uma oportunidade de mudança de vida, um passaporte para o conhecimento, a formação do aluno perante a sociedade, bem como as descobertas de infinitas possibilidades no tocante ao discernimento entre o bom e o ruim.

5.3 Figura 15 - mapa mental 15 - menina / idade não especificada

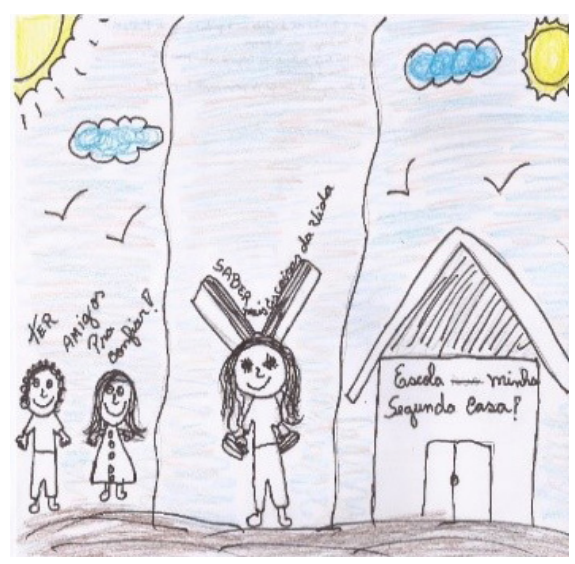

- Podemos observar nesta figura a divisão de três mensagens, sendo, na primeira (da direita para a esquerda) representada a estrutura da escola, tendo na parede, acima da porta, a frase: "Escola - minha segunda casa!". Também é representado um céu azul com nuvens, um sol e pássaros voando. Na segunda, aparece 
uma menina sorridente e com olhar expressivo, com um livro aberto surgindo de sua cabeça e, de dentro do livro, a frase: "Saber mais as coisas da vida". A menina está em um ambiente sem paisagem natural ou construída, apenas destacado o céu azul. Na terceira cena, observa-se um menino e uma menina, expressando alegria e com ares receptivos, em um ambiente com um grande sol disposto no canto superior esquerdo, nuvens e pássaros voando. Acima da figura do casal está a frase: "Ter amigos pra confiar!".

- Em relação à forma de representação dos elementos na imagem, podem-se observar ícones de desenho, complementação de palavras, representação de espacialização do fenômeno "escola" e do espaço físico.

- Quanto à interpretação de distribuição dos elementos na imagem, o mapa apresenta-se em perspectiva e forma horizontal.

- Sobre a especificação dos ícones, nota-se a representação de elementos das paisagens naturais, construídas, e elementos humanos.

- Analisando os outros aspectos e particularidades deste mapa, observamos que, independente das palavras complementares, fica clara a associação da escola com a casa pela aluna, uma vez que o desenho faz menção à sua segunda casa, exposta em um cenário alegre. Em relação à menina que tem o livro saindo de sua cabeça, a alegria em busca do conhecimento é nítida e, quanto ao casal, pode-se observar facilmente a afetividade entre eles, assim como a satisfação de se encontrar amigos na escola. Com isso, temos o significado da escola, para a aluna, como uma expectativa para o conhecimento, como ambiente de aprendizagem, local onde se faz novas amizades. 
5.4 Figura 16 - Mapa mental 16 - menino / 14 anos

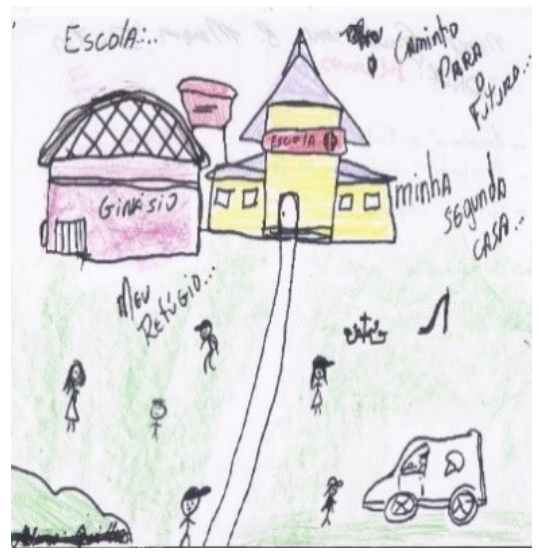

- Neste mapa, foi especificada, pelo aluno, a figura da escola, com detalhes em 3D, tendo ao seu lado esquerdo a representação do ginásio e, entre os dois, uma caixa d'água. Da escola sai um caminho que percorre toda a paisagem, tendo disposto do lado direito da escola um parquinho e, mais à frente, um carro de sorvete com um motorista dentro. Por todo o pátio há alunos dispostos, indo em direções diferentes, sendo meninos e meninas. Existem textos complementares identificando a escola e o ginásio e também expressões como: "Escola... caminho para o futuro", "Minha segunda casa", "Meu refúgio".

- Em relação à representação dos elementos na imagem, pode-se observar representação de espacialização do fenômeno escola, ícone desenho e complementação de palavras.

- Quanto à distribuição dos elementos na imagem, nota-se que o desenho está em forma horizontal e perspectiva, apresentando vista aérea, com os elementos distribuídos de maneira dispersa e isolados.

- Sobre a especificidade dos ícones, é possível observar elementos da paisagem natural, construída, a presença de elementos humanos e móvel. 
- Em análise de outros aspectos e particularidades do desenho, chama a atenção o formato da estrutura da imagem construída e sua dimensão. Quanto ao desenho da escola, embora o aluno relate que ela é vista como sua segunda casa, ele a retratou como a escola mesmo e não como uma casa, em relação aos outros mapas analisados. Apresenta a noção de um lugar agradável e atrativo, pela presença do parquinho e do carro de sorvete. Embora o aluno tenha expressado em palavras que a escola é seu refúgio e sua segunda casa, os elementos humanos representados encontram-se dispersos e isolados, sem nenhuma conexão ou expressão, representando introversão entre si. A leitura realizada é de que, provavelmente, o aluno não tenha amigos. Em texto complementar disposto no verso do desenho, o aluno expõe que "a escola é o futuro, o refúgio: problemas de fora, ginásio (esporte)". Todo este contexto revela o significado da escola para o aluno, que é um local que representa perspectivas para o futuro, demonstra satisfação em estar na escola, considerando-a refúgio para os problemas externos e seu interesse pelo esporte.

\section{Considerações finais}

O significado da escola para os alunos guajaramirenses da escola Simon Bolívar, de modo geral, está relacionado a aspectos positivos, embora no âmbito da escolaridade se depare com variáveis suscetíveis a desafios a serem enfrentados, seja no relacionamento com os estudos, professores, e colegas, seja, até mesmo, na realidade do que é esse lugar em termos estruturais, quando esta não possui espaços lúdicos de lazer desportivos, visto que toda essa conjuntura preenche o que chamamos de escola. Notadamente, a motivação para estar na escola é movida em meio a sonhos idealizados para o futuro, perspectivas de obter o conhecimento extra sala de aula, ou seja, aquisição do saber necessário para a vida e também termina por caracterizar um ambiente familiar rico de oportunidades e possibilidades de ser mais. Ao analisar os mapas, fica evidente a esperança de progresso que a escola 
representa para o alunado, exteriorizado no papel, seus pensamentos e, por que não, desabafos? $O$ entendimento de que a escolaridade é o caminho certo, para a formação do sujeito, foi revelado através dos signos, pois os alunos se referiam à escola com carinho, afeto e esperança de mudança de vida, mesmo com as lacunas que a escola possui em termos de estrutura física, transmissão e assimilação do saber.

A aplicação do mapa mental traz importantes contribuições para a pesquisa do campo educacional, visto que os alunos, ao realizarem o desenho, possuem toda liberdade de expressar efetivamente o que o está intrigando ou satisfazendo, sem influência de terceiros, sem medo do constrangimento, se comparado a exigências da fala verbal. Podem-se entender os mapas mentais como indicadores para o melhoramento do fenômeno a ser investigado, pois, diante do que foi desvelado, é possível compreender o aluno e abrir espaços de mudanças que beneficiem a todos os envolvidos. É perfeitamente possível fazer uso desse recurso em outras perspectivas e contemplar outros contextos, como a vivência familiar, a cultura de determinado povo, e verificar o que se quer investigar no coletivo ou individual, entre crianças, adultos e idosos, trazendo, portanto, prerrogativas ao estudo.

Nota-se o entusiasmo dos alunos de Guajará-Mirim perante o contexto escolar, ainda que a realidade da cidade encontre-se com poucas oportunidades e incentivos financeiros por parte do município, para otimizar a escolarização, considerando, também, majoritariamente, o estilo de vida singelo da modesta comunidade, em que prevalece ainda a afetividade típica do interior. Essas peculiaridades não são fatores de desmotivação para os estudantes dessa localidade, mas seriam tais particularidades a justificação para o contentamento deles, em ver a escola como uma esperança e caminho para o futuro? Tal questão justifica-se pelo fato de que, nos grandes centros, os mapas mentais revelaram verdades antagônicas, no qual o escolar, vivendo em condições instáveis, concernentes aos recursos que lhes são disponíveis, demonstrou demasiado dissabor. É perceptível a distinção entre as cidades; se, por um lado, acontece a harmonia de positividade do pensamento em Guajará-Mirim, no tocante ao olhar da escola pelo aluno, há a negatividade dos escolares paulistanos, em relação ao âmbito estudan- 
til. Entende-se que a cultura local e social intervém, diretamente, sobre essas percepções. Diante disso, é perfeitamente possível identificar mecanismos que viabilizem melhores condições de transmissão e apreensão do conhecimento, agora com a diagnose realizada, fazendo indagação como: o que acontece na cidade que faz com que esse paradigma se estabeleça, tanto num pequeno município, como na grande metrópole? O mapa mental traz essas discussões, a fim de encontrar práxis transformadoras para o resultado do fenômeno investigado: "a escola”.

\section{Referências}

1 SILVA, P.P. et al. Pedagogia na fronteira: linguagem e afetividade nas representações da escola por alunos haitianos e bolivianos. In: VIII mostra nacional de iniciação cientifica e tecnológica interdisciplinar, 2015, Santa Catarina. Anais. IFC, 2015. pág. 1.

2 . Santa Catarina. Anais. IFC, 2015. pág. 2.

3 IBGE. População Guajará-Mirim em 2018. Disponível em: https://cidades.ibge.gov.br/ brasil/ro/guajara-mirim/panorama. Acesso em 15/09/2018.

4 MATIAS, F. Formação Histórica de Rondônia e Econômica de Rondônia. Ed.3a . Porto Velho. 2010.

5 KOZEL, S. Representação do espaço sob a ótica, dos conceitos: mundo vivido e dialogismo. In: XVI Encontro Nacional dos Geógrafos, 2010, Porto Alegre. Anais. Porto Alegre: AGB, 2010. pág. 2.

6 . Porto Alegre. Anais. Porto Alegre: AGB, 2010. pág. 1.

7 FILHO, F. S. M. e OLIVEIRA, I.J. de. Apud KOZEL, Salete. Da percepção e cognição a representação: reconstruções teóricas da geografia cultural e humanista. São Paulo:Terceira Margem, Curitiba: NEER, 2007. pág. 37.

8 KOZEL, S. e GALVÃO. W. Representação e ensino de geografia contribuições teóricos -metodológicas. Ateliê Geográfico, Goiânia, v. 2, n³, dezembro. 2008. Pág.40.

9 _. Representação e ensino de geografia contribuições teóricos -metodológicas. Ateliê Geográfico, Goiânia, v. 2, n³, dezembro. 2008. Pág.46.

10 FILHO, F. S. M. e OLIVEIRA, I. J. de. A utilização de mapas mentais na percepção da paisagem da cultural da cidade de Goiás/GO. Revista de Cultura e Turismo, Goiás, $n^{\circ} 3$, outubro. 2013. pág. 36. 
11 SANTOS, Z. G. C. e PEREIRA, R. M. C. A cidade pelo olhar do imigrante: uma leitura de mapas mentais. In: V NEER, Mato Grosso. Anais. UFMT. pág. 4.

\section{Obras consultadas}

COLARES, A. A.; Colares, M. L. I. S. Fontes para Estudos Históricos da Educação Escolar na Região do Vale do Guaporé/RO. Disponível em: www.histedbr.fe.unicamp.br/ acer_histedbr/seminario/seminario8/_.../BlpEL1H7.doc. Acesso em: 22/08/18

DIÁRIO RO. Diários Municipais. 2017. Disponível em: http://www.radaroficial.com. br/d/6278518878240768. Acesso em: 22 ago.18

EDUCAÇÃO, Portal. Organização do sistema educacional brasileiro. Disponível em: https:/www.portaleducacao.com.br/conteudo/artigos/educacao/organizacao-do-sistema-educacional-brasileiro/34900. Acesso em: 14 ago.18

FURASTÉ, P. A. Normas Técnicas para Trabalho Científico: explicitação das normas da ABNT. 17. ed. Porto Alegre: Dáctilo Plus, 2015.

MOREIRA, C. Sistema Municipal de Ensino: diferente do "sistema educacional brasileiro”. Disponível em: https://cmoreira2.jusbrasil.com.br/artigos/424866508/sistema-municipal-de-ensino. Acesso em: 14 ago.18

SILVA, F. B. da. O Papel do Conselho Estadual de Educação no Sistema Estadual de Ensino de Rondônia. Maceió/AL, 2015. Disponível em: http://fncee.com.br/wp-content/uploads/2015/06/ROND\%C3\%94NIA-O-papel-do-Conselho-Estadual-de-Educa\%C3\%A7\%C3\%A3o-no-Sistema-Estadual-de-Ensino-de-Rond\%C3\%B4nia-1.pdf. Acesso em: 22 ago.18 


\section{ESPAÇO ESCOLAR E IDENTIDADE: ANÁLISE DE MAPA'S MENTAIS DE ALUNOS DE UMA ESCOLA MUNICIPAL EM PORTO VELHO/RO}

Solimária Pereira Lima'

Ednalva Oliveira Silva²

Geiza dos Santos Mendonça ${ }^{3}$

Iza Reis Gomes Ortiz

\section{Introdução}

Este artigo tem por objetivo analisar a percepção de alunos e alunas sobre o espaço formativo "escola" a partir de desenhos produzidos por elas, os quais chamaremos aqui de mapas mentais, ou seja, "uma forma de linguagem que retrata o espaço vivido representado em todas as suas nuances, cujos signos são construções sociais. Eles podem ser construídos por intermédio de imagens, sons, formas, odores, sabores, porém seu caráter significativo prescinde de uma forma de linguagem para ser comunicado" (KOZEL, 2009, p.1). Assim, nossa abordagem será uma análise dos mapas mentais construídos por alunos(as) haitianos(as), nos anos de 2014 e 2015, resultados de uma pesquisa de campo do projeto de pesquisa

\footnotetext{
${ }^{1}$ Graduada em Letras, Mestre em Letras. Técnica em Assuntos Educacionais do IFRO. Pesquisadora do GET/IFRO. E-mail: solimaria.lima@ifro.edu.br.

${ }^{2}$ Formada em Pedagogia pela Universidade Federal de Rondônia - UNIR e Psicologia pela Universidade Federal da Bahia - UFBA. Pós-graduada em Potenciais da Imagem: recursos multimidiáticos, fotografia, vídeo, computador, nas Ciências Humanas pela Universidade Federal da Bahia e em Coordenação pedagógica pela Universidade Federal de Rondônia - UNIR.

${ }^{3}$ Graduada como Tecnóloga em Gestão Pública/IFRO, Pesquisadora do Grupo de Pesquisa em Educação a Distância - GPED/IFRO, Departamento de Educação a Distância do IFRO/DEPEaD, Pesquisadora Colaboradora do Grupo de Pesquisa em Educação, Filosofia e Tecnologias - GET/IFRO GEOPEDAGOGIA/IFRO.

${ }^{4}$ Doutora em Sociedade e Cultura na Amazônia pela Universidade Federal do Amazonas - UFAM; Mestre em Letras: Linguagem e Identidade pela Universidade Federal do Acre - UFAC; Professora de Língua Portuguesa e Literatura do Instituto Federal de Rondônia IFRO.E-mail: iza.reis@ifro.edu.br
} 
Geopedagogia, realizado pelo Grupo de pesquisa em Educação, Filosofia e Tecnologias (GET), do Instituto Federal de Educação, Ciência e Tecnologia de Rondônia.

Trabalhando com Kozel (2009), nosso intuito é identificar as construções sociais, os sujeitos, os espaços, as cores, a realidade e a imaginação presentes ou não nos desenhos construídos a partir de uma pergunta motivacional: "O que é a escola para você?", buscando relacionar o conceito de escola com a identidade deles. Os alunos são haitianos matriculados em uma escola pertencente à rede municipal de ensino na cidade de Porto Velho, Rondônia.

Consideramos os mapas mentais instrumentos metodológicos que permitem aos produtores/alunos serem autores e construtores de seus próprios espaços, nesta pesquisa. São enunciados que suscitarão um diálogo entre os interlocutores, em que os alunos serão atores sujeitos de seus enunciados, de suas ideias, de suas representações sobre o ambiente escolar.

Segundo Kozel, os mapas mentais contemplam representações dos sujeitos em relação a um determinado espaço vivido. E as construções/ representações desse espaço são sociais, ou seja, refletem um contexto histórico, social, cultural, político e educacional. E analisar esses mapas pode possibilitar ao pesquisador interpretações, compreensões e percepções dos sujeitos construtores, diagnosticando situações para que a educação seja estudada e transformada para uma atuação mais realística e promotora da valorização do sujeito/aluno.

Este artigo ganha um caráter diferencial por apresentar dados de uma pesquisa realizada em um contexto histórico ímpar, momento da imigração de haitianos para o Brasil, devido ao abalo sísmico ocorrido em 2010. Na configuração escolar, encontramos alunos haitianos que, juntamente com seus familiares, encontraram como alternativa a saída de seus lares para o Brasil, numa tentativa de sobrevivência e em busca de nova possibilidade de vida em outros espaços. E a escola, como espaço formativo educacional, é um elemento imprescindível nessa reorganização de vida para esses estrangeiros. 
Em nossa análise, identificamos alguns pontos que relacionamos a essa mudança de espaço. Nos mapas mentais produzidos por haitianos, a questão de pertencimento é observada de forma clara, pois, para uma criança em desenvolvimento, pertencer a um lugar é essencial, seja na família, na escola, no bairro ou na cidade.

Nossa metodologia de apresentação de dados seguirá os seguintes passos: após a apresentação da história e cultura local, faremos uma breve explanação sobre o Sistema organizacional escolar brasileiro e de Porto Velho - Rondônia, e sobre como a Secretaria procedeu para recebimento de alunos haitianos. Em seguida, teremos uma configuração da Escola em que desenvolvemos a pesquisa. E, finalizando, faremos a apresentação dos desenhos e descrição, por meio das análises dos mapas, segundo o instrumental norteador.

\section{História e cultura local}

Buscando remontar as origens do município, constatou-se que o nome da capital do Estado de Rondônia, Porto Velho, está relacionado com a Guerra do Paraguai, ocorrida entre os anos de 1864 e 1870. Esse conflito ocorreu durante a segunda metade do século XIX, ainda no II Reinado, quando a nação estava organizada politicamente por uma Monarquia e tinha como Imperador Dom Pedro II, que governou o Brasil entre os anos de 1840-1889.

O Paraguai, além de outras intenções, ambicionava ampliar suas fronteiras, tomando posse de parte do território brasileiro localizado no centro-oeste, mais precisamente no Mato Grosso. Foi nesse contexto de conflito armado que Dom Pedro II e o comando militar resolveram instalar um contingente militar no ano de 1865, onde hoje estão os barracões do ponto inicial da Estrada de Ferro Madeira Mamoré, haja vista a fragilidade das fronteiras no extremo oeste do Brasil. Essa instalação permaneceu até o final da guerra do Paraguai, que ocorreu no ano de 1870, quando os militares se retiraram, pois não havia mais necessidade da permanência deles naquela localidade. Nesse ínterim, os trabalhado- 
res da região (seringueiros, caucheiros e caçadores) passaram a chamar a localidade de Ponto Velho dos Militares, mais tarde, Porto Velho dos Militares. (MENEZES, 1983).

O desenvolvimento da cidade de Porto Velho se deu em ritmo lento. A estrutura montada para atender às demandas da ferrovia Estrada de Ferro Madeira Mamoré trouxe consigo um grande número de trabalhadores, contribuindo assim com o processo de povoação. Porto Velho foi fundado pela empresa americana Madeira Mamoré Railway Company, em 4 de julho de 1907, durante a construção da Estrada de Ferro Madeira-Mamoré, comandada pelo magnata norte-americano Percival Farquhar. $\mathrm{O}$ povoado cresceu e aquela pequena localidade foi promovida legalmente como um município do Amazonas, com a Lei n ${ }^{\circ} 752$, do dia dois de outubro de 1914. Atualmente, o Município de Porto Velho possui 105 anos. O município de Porto velho foi transformado em capital do Estado de Rondônia no ano de 1943, quando foi criado o Território Federal do Guaporé.

Segundo Esron Penha de Menezes, "A cidade nasceu e cresceu a partir das instalações ferroviárias da Estrada de Ferro Madeira-Mamoré. Graças aos tantos ciclos econômicos que se seguiram (exploração de borracha e posteriormente de cassiterita e de ouro), o município foi se consolidando e acolhendo os migrantes que hoje formam a sua população". A população de Porto Velho é formada por um grande contingente de imigrantes. Cerca de $40 \%$ da população nasceu fora do estado.

É importante destacar que Porto Velho é uma cidade que historicamente foi formada com base em ciclos de ascensão: primeiro a construção da EFMM, que trouxe milhares de trabalhadores para efetivar a obra, e muitos deles permaneceram no município; tivemos o ciclo da borracha, que também foi um chamariz para o processo migratório e estrutural da região; após esse, tivemos ainda o ciclo da cassiterita e do ouro, que foram responsáveis pela vinda de centenas de pessoas, em sua maioria de estados brasileiros (como Ceará, Paraná, dentre outros) para o Estado de Rondônia, principalmente para o município de Porto Velho e, recentemente, consideramos como ciclo de ascensão a construção das hidrelétricas de Jirau e 
Santo Antônio, cujas obras foram iniciadas no ano de 2008 e inauguradas no ano 2016. Essas obras também foram responsáveis em trazer famílias de todo o Brasil, inclusive de outros países, como o Haiti.

Destacamos que o município de Porto Velho está localizado na Bacia do rio Amazonas, e o rio Madeira é o principal rio que banha o município, vindo do sul da Bolívia. Possivelmente, a localização estratégica e características hidrográficas do Rio Madeira contribuíram para a escolha da construção do complexo hidrelétrico.

Quanto à migração de estrangeiros, um quesito importante foi a construção da rodovia no Estado do Acre, que leva à saída para o pacífico - o que tem facilitado a entrada de migrantes principalmente para a região Norte.

A dinâmica com que ocorreu o processo migratório da força de trabalho para atuar no Complexo Hidrelétrico do Rio Madeira repercutiu em diferentes possibilidades de atuação. Diversos problemas e impactos de ordem ambiental, cultural, socioeconômica e um significativo deslocamento de mão-de-obra em busca de empregos e oportunidades de renda ocorreram com a construção das usinas hidrelétricas.

Quanto à migração das famílias dos estudantes haitianos, um fator desencadeador desse processo migratório foi, dentre outros problemas, um abalo sísmico ocorrido no Haiti no ano de 2010. Esse terremoto teve proporções catastróficas, alcançando a magnitude 7,0 na escala Richter. Cerca de três milhões de pessoas foram afetadas pelo sismo; esse acontecimento acabou por dizimar entre 100.000 a 200.000 pessoas, conforme Paula,(2013). Foi um desastre natural que desestruturou o país por completo.

$\mathrm{Na}$ tentativa de fugir das consequências desse desastre, atrelado a outros fatores como o possível ambiente favorável de grandes investimentos que estava acontecendo na Região Norte; as obras de infraestrutura no segmento energético; a possível efetivação da Ponte de Integração e 
Estrada do Pacífico, também conhecida como Rodovia Interoceânica ${ }^{5}$, em 2014; e os Jogos Olímpicos em 2016, motivaram os haitianos e as haitianas a escolherem o Brasil como alternativa para uma vida melhor. (ANA THOMAZ, 2013).

Com o desastre natural (terremoto ocorrido em janeiro de 2010), os desastres sociais resultantes da exploração econômica do Haiti e desgaste estrutural das instituições públicas haitianas, muitos haitianos e haitianas decidiram deixar seu país e emigrar para outros países, principalmente para o Brasil, a partir do final do ano de 2010, numa jornada repleta de dificuldades. (PAULA, 2013)

Segundo o autor (2013), além desses fatores estruturais, os haitianos e as haitianas vislumbravam o Brasil como um país de mercado econômico emergente, que, possivelmente, seria um fomentador de expectativas de obtenção de emprego e estabilidade, e acreditavam que, havendo crescimento, haveria demanda de força de trabalho. No entanto, o autor destaca que esse pensamento de trabalho fácil em muito foi frustrado. De início, o deslocamento dos haitianos e das haitianas até a chegada ao Brasil envolveu uma série de questões ilegais e violações de direitos humanos. Na chegada à fronteira do Peru com o Brasil, principal porta de entrada, em alguns períodos, os haitianos foram impedidos de entrar.

Nesse contexto, ocorria o auge da construção das Hidrelétricas em Rondônia. A dinâmica que implicou o processo migratório da força de trabalho para atuar no Complexo Hidrelétrico do Rio Madeira repercutia em diversas áreas.

Esse processo de migração em massa trouxe consigo as diversas demandas: escolas para os filhos e filhas dos trabalhadores, saúde pública, moradia, dentre outras. Juntamente com seus pais, algumas crianças vieram

\footnotetext{
${ }^{5}$ A Rodovia Interoceânica foi projetada para assegurar a ligação terrestre do oceano Atlântico brasileiro até o Oceano Pacífico peruano. É o maior e principal projeto de infraestrutura da América do Sul, por se tratar de um corredor terrestre para o fluxo de mercadorias. Favorece a integração sul-americana, a aproximação entre povos e culturas, favorece a circulação de pessoas, é dinamizador do turismo e facilitador do comércio bilateral no Brasil. Essa estrada garante o acesso dos produtos peruanos ao Oceano Atlântico e dos produtos brasileiros ao Oceano Pacífico. Tem favorecido a entrada de migrantes para a região Norte e, a partir daí, para outras regiões do Brasil. (ALMEIDA, 2013).
} 
do Haiti para o Brasil, especificamente, para a cidade de Porto Velho, no estado de Rondônia.

\section{A educação como direito fundamental}

A educação "é a ação exercida pelas gerações adultas sobre as gerações que não se encontram ainda preparadas para a vida social”, revela Durkheim, citado por Brandão (2007 p. 71).

Especialistas conceituados definiram a educação. Para Santos, citado por Sidónio Farias (2007, p. 2), em seu artigo intitulado Pedagogia, a educação é entendida como uma prática que "pretende levar ao desenvolvimento de todas as facetas da personalidade humana". Para Cohn, citado por Brandão (2007, p. 65), "é a influência deliberada e consciente exercida sobre o ser maleável e inculto, com o propósito de formá-lo”; e, ainda, para Kerschensteiner (apud Brandão, 2007, p. 64), "educação é um sentido de valorização individual, variável em extensão e profundidade para cada indivíduo e processado pelas riquezas culturais”.

Assim, em todas as sociedades o homem se vê envolvido com alguma forma de Educação, pois, através dela, busca preparar os indivíduos para enfrentarem a realidade social.

No Brasil, a Constituição Federal, em seu artigo $6^{\circ}$, eleva a Educação à categoria de direito social, considerando-a como essencial para a garantia do Princípio da Dignidade da Pessoa Humana e, nesse processo, a escola tem o papel de formar cidadãos, promovendo sua formação integral.

Em relação ao recebimento de alunos estrangeiros na rede estadual de ensino em Porto Velho, o Estado apresenta regulamentações específicas, considerando a realidade local, que tem como característica o recebimento em suas escolas de alunos imigrantes oriundos de outros países, em especial bolivianos e haitianos, em Porto Velho/RO.

A Resolução 150/2000, CEE/RO, fixa normas para matrícula, equivalência e validação de estudos, revalidação de certificados e diplomas de alunos oriundos de estabelecimentos escolares estrangeiros, e dá outras providências. 
A Norma prevê que alunos oriundos de escolas em país estrangeiros poderão se matricular, desde que cumpram algumas exigências, que são: documento escolar autenticado pelo Consulado Brasileiro e tradução oficial formalizada.

No entanto, em razão do abalo sísmico, a maioria dos haitianos não possuía documentação formalizada, e outros sequer possuíam documentos, que se perderam com o terremoto.

Após tentativa de resolução da situação e buscando efetivar a matrícula, a fim de oportunizar aos alunos o direito de frequentar a escola, a instituição resolveu proceder uma avaliação diagnóstica dos alunos, para posterior legalização da vida escolar das crianças, aos que não possuíam documentação completa.

A maioria das escolas na capital encontrava-se na mesma situação e, em razão de essa escola ter se sensibilizado com a causa - e recebido a maioria dos estrangeiros - ficou conhecida como a escola dos haitianos.

A Universidade Federal de Rondônia - UNIR, também entrou nesse processo de inclusão e, nesse ano de 2018, já recebeu os primeiros alunos haitianos em suas turmas de ensino superior, no curso de Filosofia.

\section{Relato de campo}

O projeto Geopedagogia, vinculado ao programa Institucional de pesquisa do Instituto Federal de Rondônia - IFRO, foi desenvolvido em escolas brasileiras, haitianas e bolivianas, através de uma ferramenta chamada mapas mentais, por meio dos quais foi feita a aplicação de uma oficina que envolvia alunos brasileiros, haitianos e bolivianos.

O objetivo do trabalho foi que as crianças fizessem uma representação sobre a escola onde elas estudavam. O projeto envolveu duas formas de trabalho de campo: o suporte teórico - metodológico da aplicação dos mapas e a pesquisa etnográfica.

A metodologia dos mapas mentais foi desenvolvido pela professora Salete Kozel, que afirma: 
Os mapas mentais são desenhos concebidos a partir das observações sensíveis, da experiência humana no lugar e não se baseiam em informações precisas e rigorosamente estabelecidas, porque, "a razão objetiva, [...] se refere à existência humana mesmo que esta não possa ser expressa em categorias de quantidade", (HOLZER, 2006, p. 202).

"A existência é intermediada por símbolos." (KOZEL, 2009)

A metodologia dos mapas mentais prevê a necessidade de reflexão sobre as imagens construídas, considerando as subjetividades e experiência sociocultural de cada indivíduo. A autora preconiza "que o processo de construção ou decodificação de uma imagem passa por diferentes filtros e linguagens, particulares de cada indivíduo, que estabelece seus códigos de acordo com sua visão de mundo" (KOZEL, 2007)

Com isso, evidencia-se a crescente ascensão do uso da metodologia de mapas mentais, pois este é uma ferramenta que ajuda a melhor entender a realidade sociocultural que se pretende analisar, uma vez que demonstram a real percepção dos pesquisados sobre determinado lugar.

Uma das escolas brasileiras, cujos alunos participaram deste projeto/ trabalho para a aplicação dos mapas mentais, foi uma escola localizada na região central na cidade de Porto Velho - RO, que no ano de 2014 acolhia alunos imigrantes.

A aplicação da metodologia mapas mentais na Escola ocorreu envolvendo diversas turmas, entre elas, as turmas que recebiam alunos imigrantes. O objetivo da aplicação dos mapas era que os alunos respondessem ao seguinte questionamento: $\mathrm{O}$ que é a escola para você?

Para a realização desse trabalho, os alunos receberam materiais para desenho e pintura (lápis, lápis de cor e papel), para que pudessem elaborar seu próprio mapa. Foi dessa forma que cada aluno criou seu desenho, mostrando o significado da escola. Durante a aplicação dos mapas, observamos que os alunos eram bastante dedicados e atenciosos, enquanto desenhavam e usavam bastantes cores, para simbolizar a importância da escola.

Cada criança demonstrou de forma diferente o que a escola representava para eles, e serão apresentados 6 (seis) mapas mentais produzidos 
por esses estudantes, para que seja possível constatar e verificar como os estudantes consideram a escola que frequentam e que representações foram criadas.

\section{Análise dos mapas}

Exporemos então as análise de mapas mentais apresentados por alunos do Ensino Fundamental, em que retratam suas percepções acerca da Escola. O desenho dos mapas foi produzido a partir do seguinte questionamento: O que é a escola para você?

Foram produzidos 22 (vinte e dois) mapas mentais, dos quais 6 (seis) serão analisados neste artigo.

Como, os alunos poderiam produzir livremente os mapas mentais a respeito da escola, não foi apresentado a eles nenhum roteiro ou esquema de mapa a ser seguido.

Após os alunos apresentarem seus mapas para a equipe de pesquisa, esta se dividiu em grupos e buscou saber, dos próprios alunos, o significado dos mapas desenhados, a fim de facilitar a compreensão por parte da equipe que iria analisar os mapas mentais, o que foi feito com base na metodologia Kozel.

Os mapas foram analisados das seguintes perspectivas:

a) Interpretação quanto à forma de representação dos elementos na imagem: letras, mapas, linhas, figuras geométricas, palavras etc.

b) Interpretação quanto à distribuição dos elementos na imagem: perspectivas na horizontal, de forma isolada, em perspectiva etc.

c) Interpretação quanto à especificidade dos ícones: representação dos elementos da paisagem natural; da paisagem construída; dos elementos móveis; dos elementos humanos etc.

d) Apresentação de outros aspectos ou particularidades: representações sobre a escola. 
Vejamos as análises:

Figura 1 - Mapa 8 - Produzido por um aluno do $5^{\circ}$ ano, 12 anos

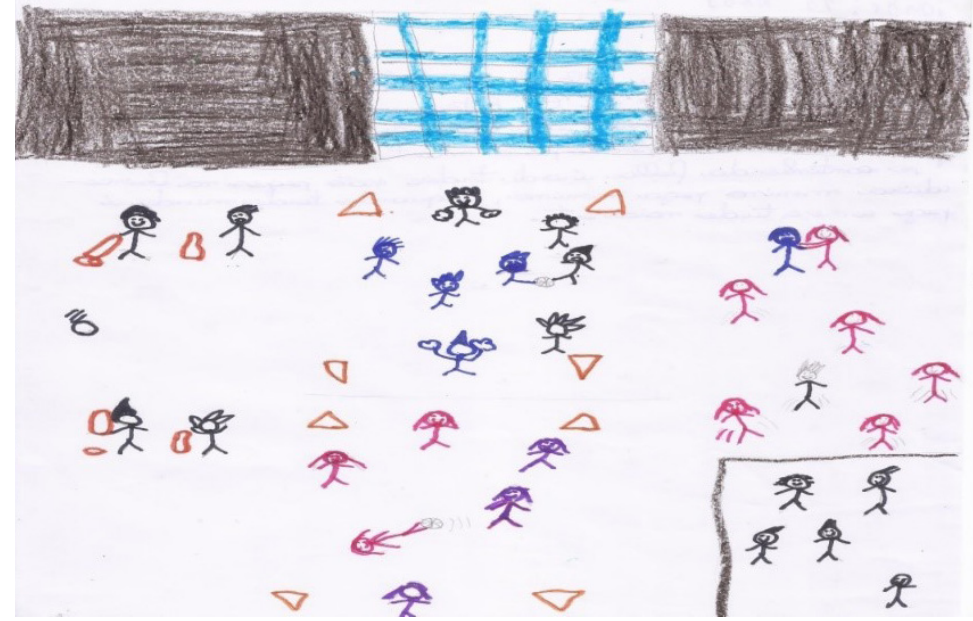

Fonte: Trabalho de campo Projeto Geopedagogia 2014-2015

O Mapa 8 teve a seguinte descrição:

Em relação a elementos naturais, o aluno não apresentou tais itens. Com relação aos elementos construídos, apresenta o muro e portão, devidamente trancados. No pátio da escola, pode-se observar a presença de várias crianças que se divertem com diversas brincadeiras.

O Mapa 8 foi produzido por um estudante do $5^{\circ}$ ano, com 12 anos de idade. Sobre a representação no mapa, o aluno explica que: "O desenho significa a aula de educação física. As pessoas são alunas da $5^{a}$ A e B, estão jogando futebol, pega e bets. De azul e preto é o muro do portão, para manter a escola segura."

O lugar representado é o pátio da escola durante uma aula de Educação Física, com a realização de várias brincadeiras; é clara a percepção que o aluno tem da escola como um local divertido, pois apresenta vários ambientes de interações e brincadeiras. $\mathrm{O}$ brincar tem um destaque especial nesse mapa, pois são representados os jogos de futebol, betes e pega-pega. Durante a aula, ocorrem 3 diferentes tipos de jogos, o que permite o envolvimento de várias crianças. 
Durante a busca pela interação entre os atores escolares, pode-se destacar que essa convivência e interação entre alunos pode ser sinalizada como uma busca de se auto afirmar e identificar.

No entanto, mesmo nesse clima de descontração é preciso observar que o aluno está preocupado com a segurança da escola, pois o muro é grande e ele deixa bem claro que o portão encontra-se fechado para segurança de todos. A preocupação com a segurança e o fechamento dos portões provavelmente se relaciona com situações de insegurança vividas anteriormente, possivelmente relacionado com o abalo sísmico vivido pelos haitianos.

Sobre a representatividade do lugar que contém as experiências do sujeito e é impregnado de histórias e símbolos, Kozel (2009, p. 211) afirma que: "o homem medeia as relações, constrói o lugar com as topofilias ou topofobias e forma elos afetivos com os membros do grupo cultural".

Apresentam-se muitas cores, com destaque para o visual colorido do desenho.

Sobre a representatividade das cores, TUAN (1980) afirma:

A sensibilidade humana para as cores manifesta-se em idade muito precoce. Até bebês de três meses de idade parecem ser capazes de fazer discriminações. As cores desempenham um papel importante nas emoções humanas, podem construir os primeiros símbolos do homem. As cores primárias designam emoções fortes. As crianças pequenas parecem ter pouco interesse pelas cores mistas ou impuras. (p. 29)

Nesse mapa, observa-se em destaque a presença do elemento humano, com a presença de muitas crianças que interagem entre si, sendo a interação e a brincadeira algo marcante no mapa.

$\mathrm{O}$ aluno representa um momento da brincadeira pega-pega, em que as crianças vão sendo pegas e devem se posicionar no quadrado do canto; quando todas forem pegas a brincadeira recomeça. A presença recorrente do elemento humano indica a preocupação do aluno com a convivência e interação, e a constatação de que a escola poder ser um local para criar laços. 
Nesse mapa não há presença de elementos da natureza.

Existe uma organização geométrica dos desenhos, onde se percebe a presença de formas quadradas e retangulares, além da distribuição dos alunos no espaço de forma agrupada.

Apresentam-se 3 blocos de organização: os que brincam de futebol, estão em um bloco; os que brincam de betes, estão em outro; e os que brincam de pega-pega estão no terceiro bloco. A organização em blocos e formas remete à estrutura de disposição da organização escolar.

Em relação ao espaço construído, observa-se a presença de um muro e um portão, que se encontra fechado. $\mathrm{O}$ muro e portão fechados podem representar a sensação de segurança que as crianças sentem ao estarem dentro da escola.

Uma diversidade de cores aparece no mapa: marrom, azul, preto, vermelho, laranja, com destaque para a cor marrom, que recobre o muro.

Figura 2 - Mapa 5 - Produzido por aluno do $3^{\circ}$ ano, 10 anos

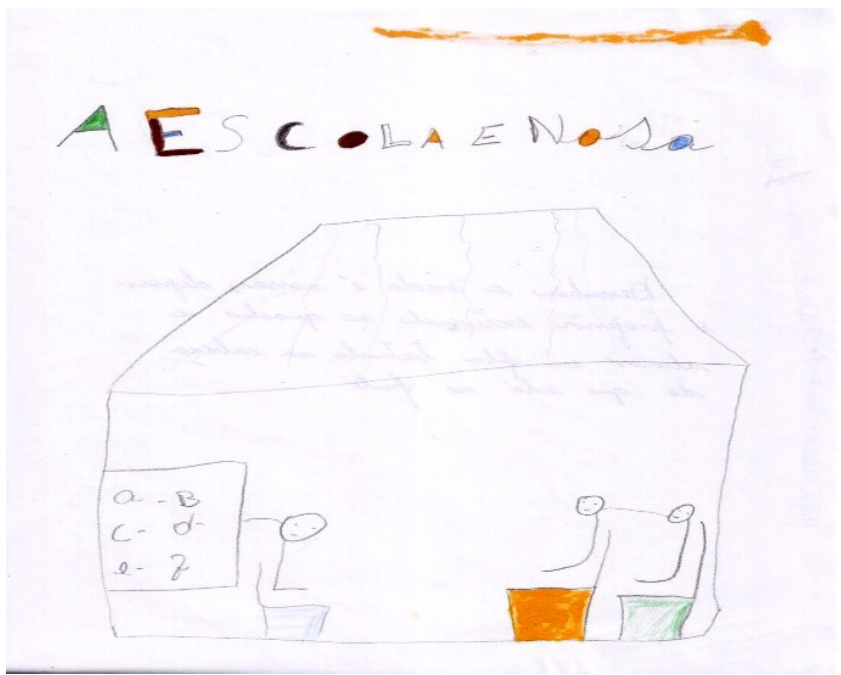

Fonte: Trabalho de campo Projeto Geopedagogia 2014-2015

No Mapa 5, o segundo a ser analisado, também destacamos a ausência de elementos naturais no desenho. O elemento construído é a escola, e temos os seguintes destaques em relação ao elemento humano que se encontra representado pelas crianças e professor. 
- Como elementos móveis, observamos a presença de cadeiras e quadro branco que compõem a cena.

Ao ser solicitado que esclarecesse o mapa, o aluno afirma que: "Desenhou a escola é nossa, depois o professor escrevendo no quadro e alunos em fila batendo na cabeça do que está na frente."

O Mapa 5 foi produzido por um estudante com 10 anos de idade do terceiro ano do ensino fundamental.

Nesse mapa, observamos a presença de elementos humanos que expressam a relação professor-aluno. O lugar representado é a sala de aula e o professor é desenhado no exercício docente, com destaque para os assentos, os quais são apresentados com cores. A apresentação da professora que está sentada e explicando o alfabeto também é evidenciada.

A posição física das carteiras em sala de aula e a estratégia didática docente do $\mathrm{ABC}$ apresenta um modelo tradicional de ensino, e pode-se inferir que o aluno encontra-se habituado a esse modelo, não havendo muita aproximação com formas alternativas de interação em sala de aula.

As expressões faciais, tanto de alunos quanto do professor, demonstram seriedade. Não há sorrisos. No entanto, observamos que nos assentos da escola e na frase "A escola é nosa" são utilizadas as cores. Os assentos são bases que sustentam tanto os estudantes quanto a professora. Nesses, observamos uma expressão inconsciente, relacionada ao sentimento de base, proteção, e o aluno usa o pronome 'nosa', buscando o sentimento de pertencimento, como meio de representar sua identidade.

A presença de elemento gráfico expressa que o aluno desejou reforçar alguma mensagem, a qual apresenta uma forte demanda para quem é imigrante ou que ainda não está incluído de forma satisfatória: "A escola é nosa". A ortografia em construção expressa mais que um processo de alfabetização em curso; demonstra o desejo de sentir-se incluído e a afirmação de uma compreensão da escola como espaço de interação social. O desenho possui formas grandes, mostrando segurança de quem o produziu. 
Figura 3 - Mapa 6 - Produzido por um aluno do $5^{\circ}$ ano, 11 anos.

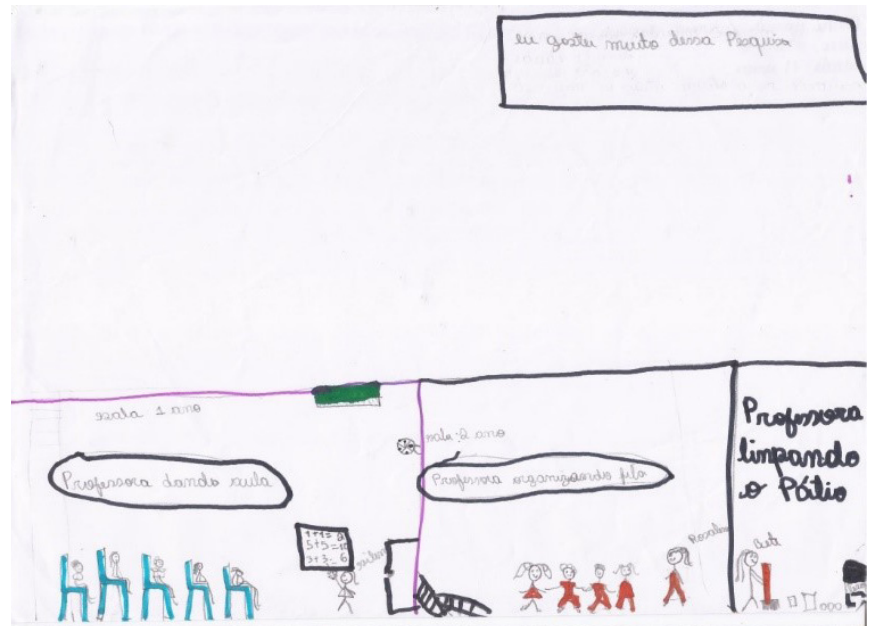

Fonte: Trabalho de campo Projeto Geopedagogia 2014-2015

Mapa produzido por uma estudante do $5^{\circ}$ ano do ensino fundamental, de 11 anos de idade.

$\mathrm{Na}$ figura do Mapa 6, observamos a presença de elementos humanos que expressam a relação professor-aluno. $\mathrm{O}$ lugar representado é composto por 3 ambientes diferentes da escola: no primeiro quadrante, a sala de aula, com o professor desenhado no exercício docente. No segundo quadrante, temos a professora e os alunos no corredor da escola; e, no terceiro quadrante, temos uma professora no pátio da escola juntando os lixos.

Observamos que essa preocupação em apresentar a escola toda dividida/organizada em blocos pode representar o próprio papel da escola para o aluno, que é de organização e aprendizado.

Tanto no segundo quanto no terceiro ambiente (quadrante), as expressões faciais dos alunos e das professoras demonstram expressões de sorrisos, discordando de um estudante no primeiro quadrante.

A ortografia apresentada demonstra a preocupação da estudante em mostrar funções exercidas pelas professoras na escola, e a professora limpando o pátio da escola pode indicar apreço e cuidado da professora para com o ambiente escolar. 
Há um destaque para a representatividade da figura professora, pois nos três quadrantes a estudante menciona três professoras diferentes, e nenhuma das três é a sua professora de sala de aula. Todas as professoras citadas são professoras de outras turmas e anos diferentes da aluna em questão. A figura repetida de diversas professoras nos mapas indica que o aluno valoriza muito esse papel do professor, pois o apresenta de forma recorrente.

A posição física das carteiras em sala de aula e a estratégia didática docente das continhas matemáticas apresentam um modelo tradicional de ensino. $\mathrm{O}$ aluno demonstra mais familiaridade com essa metodologia.

Dentre as três cores usadas pela estudante, há uma maior utilização da cor preta.

Com relação às cores, Tuan (1980, p. 29) apresenta a seguinte questão:

Os tons escuros estão associados à tristeza e impureza. Para a tribo Nupe, da Nigéria, o preto significa a feitiçaria, a maldade e presságios amedrontadores. Uma razão para a resposta negativa ao preto pode estar no horror infantil da noite, um período de isolamento, sonhos perturbadores e pesadelos, quando a invisibilidade da família encoraja a fantasia desenfreada. Há também o medo da cegueira.

Dessa forma, a predominância de cores escuras pode simbolizar o medo e horror a algo, mesmo que de forma implícita.

Perguntado sobre o significado do desenho, o aluno informa que: "são duas turmas diferentes e o pátio", e que "a professora limpa o pátio, organiza a fila dá aula”. 
Figura 4 - Mapa 15 - Produzido por um aluno do $5^{\circ}$ ano, com 11 anos de idade

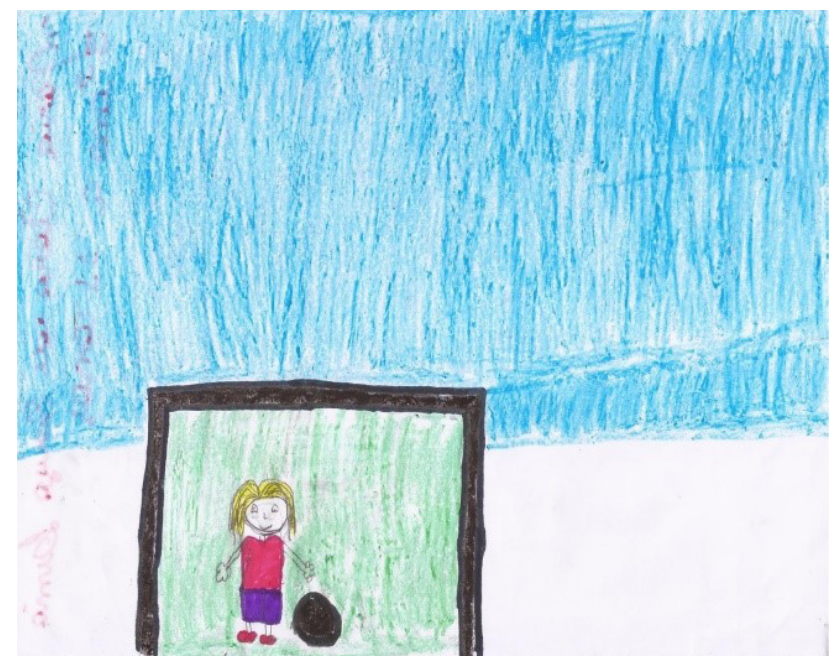

Fonte: Trabalho de campo Projeto Geopedagogia 2014-2015

Mapa produzido por um estudante de 11 anos, matriculado no $5^{\circ}$ ano.

$\mathrm{Na}$ figura do Mapa 15, vemos que existe a presença de elemento humano e elemento construído. No entanto, o elemento humano, uma criança, encontra-se sozinha em todo o mapa/desenho.

Apesar de a criança encontrar-se sozinha, ela demonstra uma expressão de felicidade, pois está fazendo algo de que gosta muito, que é jogar futebol. No entanto, o fato de a criança encontrar-se sozinha no ambiente escolar pode demonstrar solidão.

Observa-se a presença de uma bola e da trave, que são elementos móveis, pertencentes ao jogo apresentado. Os elementos móveis podem indicar a flexibilidade do aluno em relação ao ambiente escolar.

Em relação à paisagem natural, o céu retratado é muito azul e aparenta ser um dia lindo de calor. $\mathrm{O}$ sol forte e claro são indícios de um dia agradável.

Quanto à distribuição dos elementos na página, o desenho ocupa toda a folha e, considerando as formas geométricas, o desenho apresenta-se em quadrados bem definidos. 
Observando-se a disposição de cores, o desenho apresenta as cores azul, preto, verde, amarelo, rosa e violeta, com destaque para o azul do céu.

Sobre o uso da cor azul, (TUAN, 1980, p. 27) afirma que "O verde, o azul, e o azul-verde são conhecidas como cores recuadas, sugerem frieza. Um objeto pintado de azul é sempre julgado mais leve do que é." No mapa apresentado o azul simboliza o céu, que ocupa mais da metade da folha.

Indagado sobre o desenho representado no mapa, o aluno afirma: "significa que a escola é um ótimo lugar para jogar futebol, é o que mais gosto de fazer".

Nesse mapa, podemos afirmar que para o aluno a identidade/ referência que ele tem da escola é considera-la como local de diversão.

Figura 5 - Mapa 13 - Produzido por um aluno do $3^{\circ}$ ano, 13 anos

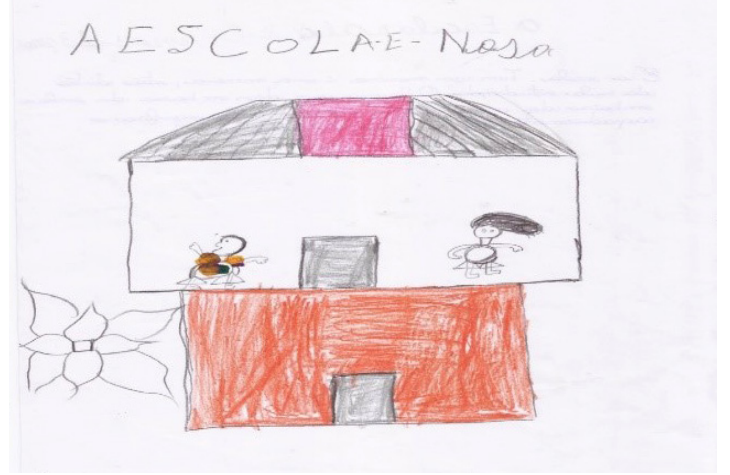

Fonte: Trabalho de campo Projeto Geopedagogia 2014-2015

O mapa apresenta as seguintes características em relação aos seus elementos: Naturais, o aluno apresenta o chão e uma flor. $\mathrm{O}$ elemento construído nesse mapa é a escola, que se encontra firmemente ancorada no chão. Com relação aos elementos humanos, observamos a presença de professor e criança, importantes atores no ambiente escolar.

O Mapa 13 foi produzido por um aluno de 11 anos, matriculado no $3^{\circ}$ ano.

Observa-se retratados, no presente mapa, elementos da natureza, representado por uma flor que, nesse contexto, pode significar demonstração de gratidão e felicidade pela escola. 
Como elemento construído, observa-se a apresentação da escola com porta e telhado bem definidos. Essa preocupação do aluno em ter o chão sob seus pés é uma forma de constatar que o aluno busca segurança.

Abaixo da escola, o aluno apresentou uma área marrom, que informou ser o chão, lugar em que a escola encontra-se bem fixada. Pode ser feita alusão ao fato de que o aluno precisa confirmar que a terra não sofrerá nenhum abalo sísmico, o que de fato ocorreu na sua terra natal, e foi um dos fatores que motivou a saída dos seus pais do país de origem, o Haiti.

Temos a presença de 2 crianças, sendo um menino e uma menina, que compõem o elemento humano no mapa.

Com relação ao feminino e masculino, apresentados de maneira clara no mapa, recorremos à análise de TUAN (1980, p. 65), que dispõe: "Masculino e feminino não são distinções arbitrárias. As diferenças fisiológicas entre homem e mulher são claramente especificáveis e pode-se esperar que estas diferenças afetem o modo de responder ao mundo.” Essa possibilidade não ficou despercebida ao aluno que desenhou o mapa, e as crianças foram representadas pelo masculino e feminino, o que possibilita distintas realidades a cada um.

E ainda o texto "a escola e nosa" que retrata a tentativa de afirmar o pertencimento ao local, além de apresentar a ortografia em processo de construção, confirmando sua nacionalidade imigrante, mas com desejo de firmar nesse novo local, considerando-o como seu.

Figura 6 - Mapa 20 - Produzido por um aluno do $3^{\circ}$ ano, 8 anos.

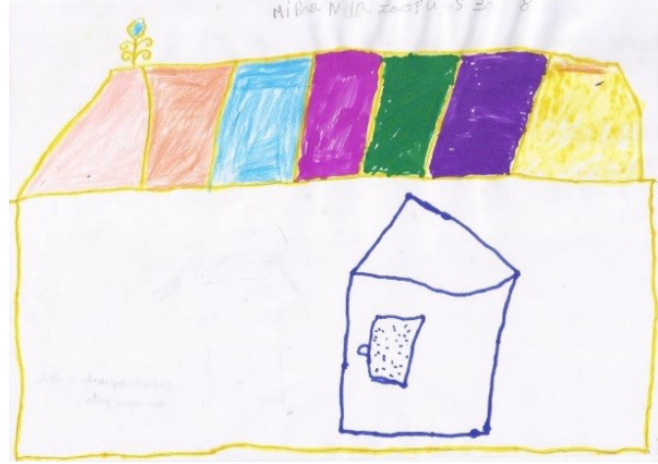

Fonte: Trabalho de campo Projeto Geopedagogia 2014-2015. 
Em relação ao Mapa 20, reproduzido na Figura 6, não há registro de elementos naturais, humanos, móveis.

O Mapa 20 foi produzido por uma estudante de idade não informada, do terceiro ano do ensino fundamental.

O lugar representado é a escola, e somente a parte física estrutural do prédio. Não há a presença de nenhuma figura humana no mapa em questão. Existe expressão de figura viva, talvez, na pequena flor que aparece em cima do telhado da escola. Figura essa existente apenas na visão da estudante, pois não há na escola nenhuma planta, flores, nem árvores.

A porta de entrada da escola é apresentada de forma diferente da real, pois a estudante apresenta a parte superior da porta de forma triangular, no entanto, na realidade, a porta da escola é retangular. Não é possível precisar se a porta está fechada ou aberta. Mesmo desuniforme, os traços da porta são fortes e em cor escura.

Somente no telhado da escola são utilizadas as cores. Esse telhado é destacado em variadas cores. É a cobertura, o que protege. Nessa construção, observamos uma expressão inconsciente relacionada ao sentimento de busca de proteção.

Ao explicar sobre o significado de seu mapa, a aluna respondeu: "O desenho representa a escola com uma porta”. Essa porta da escola pode ser interpretada de vários modos, podendo ser uma porta, uma solução, literalmente para alguém que busca auto afirmar sua identidade.

\section{Considerações finais}

Pensar a escola apenas como um espaço físico, que os alunos frequentam, de forma sistemática, sem maiores reflexões, é uma atitude a ser reformulada.

A escola é um lugar em que as crianças recebem orientações sobre o conhecimento formal e a preparação para torná-la um futuro cidadão.

Com a aplicação de mapas mentais, analisados através da metodologia KOZEL (2003), foi possível verificar o olhar dos alunos sobre esse 
processo e saber o que eles pensam sobre a escola, o que a escola significa para eles, como a escola é vista através do olhar do próprio estudante.

Essa prática se constitui de fundamental importância para fidedignidade da pesquisa, além de ser vista como referência para melhor saber atuar nas possíveis questões envolvendo os estudantes haitianos e brasileiros.

A expressão por meio dos mapas mentais possibilitou identificar muitos conteúdos, outrora não percebidos, pois os estudantes deixaram exteriorizar sentimentos e questões afetivas tanto do lugar quanto das pessoas. Puderam, também, se perceber, fazendo parte de uma construção física e afetiva. Ocorreu ainda a percepção da receptividade desse novo lar, de um sentimento de pertencimento necessário para se conviver num determinado espaço. Inclusive, surge do inconsciente e exteriorizam ao consciente a certeza de que podem ser agentes transformadores do espaço.

A problemática investigada buscou conhecer o que esses estudantes pensam da escola e quais são as representações sociais de estudantes haitianos e brasileiros sobre uma escola brasileira. Com base nessa problemática, utilizamos o Método Kozel para descrição e interpretação dos mapas mentais produzidos pelos estudantes. Os resultados indicaram diferentes representações sobre o lugar da escola em suas vidas, mas também sobre como se sentem diante dos desafios de estudar fora de seu país, sobre o tipo de acolhimento que tiveram e as relações de pertencimento e estranhamento, na referência aos estrangeiros.

Os mapas demonstram ainda que há um princípio de processo inclusivo, mas ainda com muitas dificuldades. A interação é expressa de diferentes maneiras, mas, de um modo geral, indicam o desejo do estudante estrangeiro de ser incluído na escola brasileira.

Acredita-se que alguns avanços estão ocorrendo, no entanto, enfatizamos que muitos ainda estão por vir para democratizar de forma eficaz esses ambientes, transformando os processos de ensino e de aprendizagem, respeitando as especificidades individuais.

A escola pode ser considerada uma alternativa na busca de autoafirmação de identidade. 
Face ao exposto, conclui-se que essa temática requer uma atenção especial por parte dos educadores. Nessa perspectiva, o artigo é finalizado, com a certeza de que muito ainda temos a pesquisar e com a expectativa de que esse tema tão vasto possa ganhar lugar de destaque no debate acadêmico, procurando trazer o contexto multicultural no qual as escolas estão inseridas.

\section{Referências}

ALMEIDA, C. A. de; SELEME, R.; CARDOSO, J., Neto (2013). Rodovia Transoceânica: uma alternativa logística para o escoamento das exportações da soja brasileira com destino à China.

ANA THOMAZ, D. Z. Migração haitiana para o Brasil pós-terremoto: indefinição normativa e implicações políticas. Primeiros Estudos. 2013.

BRANDÃO, Carlos Rodrigues. O que é Educação. São Paulo: Brasiliense, 2007.

BRASIL. Constituição. Brasília: Senado Federal, 1988.

BRASIL INFORME SOBRE A LEGISLAÇÃO MIGRATÓRIA E A REALIDADE DOS IMIGRANTES, São Paulo, dezembro de 2011.

PAULA, Elder de Andrade. (Des)envolvimento insustentável na Amazônia Ocidental. Rio Branco: Edufac, 2005.

PAULA, Elder de Andrade. Transgredindo fronteiras, Amazônia no espelho de Caliban. México, 2011. (mimeo).

PILETTI, Nelson. Estrutura e Funcionamento do Ensino Fundamental. 26. ed. São Paulo: Ática, 2003.

TUAN, Yi-Fu. Topofilia, um estudo da percepção, atitudes e valores do meio ambiente. São Paulo: DIFEL, 1980.

SOUSA, Domingas Luciene Feitosa. Espaço vivido e mapas mentais em escola ribeirinha Porto Velho, Rondônia. 2009. Dissertação (Mestrado em Geografia) Universidade Federal de Rondônia / UNIR, 2009.

LIMA, Angélica Macedo Lozano; KOZEL, Salete. Lugar e mapa mental: uma análise possível. Revista Geografia, Londrina, v. 18, n. 1,jan./jun. 2009 - Universidade Estadual de Londrina, Departamento de Geociências. Disponível em: http://www.uel.br/revistas/uel/ index.php/geografia/. Acesso em: 4 ago.2018.

LYNCH, Kevin. A imagem da cidade. São Paulo: Martins Fontes, 1999. 
MENEZES, Esron Penha de. Retalhos para a história de Rondônia. Porto Velho: Autor, 1983.

KOZEL, Salete; SILVA, Josué da Costa; GIL FILHO, Sylvio Fausto, (Orgs.). Da percepção e cognição a representação: reconstruções teóricas da geografia cultural e humanística. São Paulo: Terceira Margem, Curitiba, NEER, 2007

KOZEL, Salete. Comunicando e representando: Mapas como construções socioculturais. In: SEEMANN, Jörn (Org.). A aventura cartográfica: perspectivas, pesquisas e reflexões sobre a cartografia humana. Fortaleza: Expressão Gráfica e Editora, 2005.

KOZEL, Salete. As linguagens do cotidiano como representações: uma proposta metodológica possível. Disponível em: http://egal2009.easyplanners.info/area02/2088_KOZEL_ Salete.pdf . Acesso em: 11 de abril de 2018. 



\section{A ESCOLA NA PERSPECTIVA DE ESTUDANTES: UM OLHAR SOB A LENTE DE MAPAS MENTAIS}

Cláudia Gonçalves Barroso'

Luanna Freitas Johnson²

Thaís Alicea Brito ${ }^{3}$

\section{Introdução}

O que é a escola? Tal indagação suscita diferentes respostas, pois, dependendo do lugar de onde se fala, a representação sobre a escola pode tomar diferentes direções.

Apresentaremos aqui uma breve reflexão sobre representação da escola a partir de discussões suscitadas por Demerval Saviani e István Mészáros, os quais caminham para a direção que aponta a escola concebida como função transformadora da sociedade.

Em seguida, relataremos um recorte do Projeto "Geopedagogia: a escola em mapas mentais de estudantes brasileiros, haitianos e bolivianos", vinculado ao Programa Institucional de Pesquisa do Instituto Federal de Educação, Ciência e Tecnologia de Rondônia (IFRO). O objetivo da pesquisa foi conhecer representações sobre a escola de estudantes brasileiros, bolivianos e haitianos por meio de mapas mentais.

\footnotetext{
${ }^{1}$ Acadêmica do Curso de Pedagogia na Universidade Federal de Rondônia, Campus de Guajará-Mirim. Atuou como estagiária na docência do Programa Institucional de Bolsas de Iniciação à Docência (Pibid). Interessa-se por Orientação Educacional.

${ }^{2}$ Doutoranda em Educação (Dinter UEM/UNIR). Professora no Departamento Acadêmicos de Ciências da Educação na Universidade Federal de Rondônia - Campus de Guajará-Mirim.

${ }^{3}$ Acadêmica do Curso de Pedagogia na Universidade Federal de Rondônia, Campus de Guajará-Mirim. Atuou como bolsista do Programa Institucional de Bolsas de Iniciação à Docência (Pibid). Residente do Programa Residência Pedagógica. Interessa-se por Processos de Aprendizagem, Educação Especial e LIBRAS.
} 
Para atingir tal objetivo, utilizou-se o aporte teórico-metodológico da aplicação de mapas mentais, proposto pela pesquisadora Dra. Salete Kozel (UFPR). Destacaremos informações e reflexões construídas a partir dos mapas mentais aplicados a estudantes da cidade de Guajará-Mirim, Rondônia.

\section{Escola e perspectivas}

A proposta de compreender o que é a escola nos possibilita caminhos diferentes para análise. Podemos simplesmente partir do significado do termo escola, o qual deriva do latim schola, referindo-se ao estabelecimento onde se realiza qualquer gênero de instrução. É possível, ainda, fazer alusão ao ensino que se dá ou que se recebe, ao conjunto de docentes e discentes de um estabelecimento escolar, à doutrina, ao estilo de cada professor ensinar, enfim, uma instituição de ensino destinada a estudantes conduzidos pelo docente.

Para compreender o que é a escola de forma mais profunda, é necessário analisar os determinantes sociais, ou seja, deve-se pensar suas relações com as dimensões históricas, políticas, sociais e econômicas da sociedade.

Considerando o viés histórico, é possível situar as primeiras escolas no período colonial (século XV), surgidas com a chegada dos jesuítas que tinham como principal objetivo a catequização dos índios. A educação era ofertada aos indígenas em escolas improvisadas e visava principalmente à conversão destes à fé cristã. No entanto, no início da segunda metade do século XVII, é possível observar que a educação jesuítica era voltada apenas às elites econômicas coloniais (ROMANNELI, 2006).

Para FERREIRA JÚNIOR (2010), a educação jesuítica se constitui na matriz da educação brasileira, além de introduzir uma marca que parece bem atual ao cenário escolar: o elitismo e a exclusão. Segundo o autor, a escola já nasceu com o estigma de não ser para todos, pois, ao grande contingente da população colonial, era destinado o trabalho braçal e um pouco de instrução voltada para artes mecânicas. Aos homens da classe dominante era ofertada educação escolar de caráter propedêutico (estudos 
preparatórios para as artes liberais: Direito, Medicina e Engenharia), ou seja, a escola configurava-se como uma instituição que preparava o indivíduo para o exercício de um sacerdócio.

A configuração da escola nesse período possibilita identificar a separação de classes. Segundo Romanneli (2006), essa característica atravessou todo o período colonial e imperial, atingindo ainda o período republicano, sem apresentar nenhuma mudança estrutural, mesmo com o aumento da demanda social da educação, que obrigou a sociedade a ampliar a oferta escolar para admitir as camadas mais baixas da população.

Ao longo dos anos, diferentes teorias da educação foram se constituindo, porém, a representação da escola não parece ter acompanhado tais mudanças. Na percepção de Mészáros (2005), nos últimos 150 anos a escola serviu tanto para o propósito de fornecer conhecimento e mão de obra necessária à máquina produtiva, como para gerar e transmitir valores que legitimam os interesses dominantes. Para ele, as classes dominantes impõem uma educação para o trabalho alienante que tem como objetivo manter o homem dominado, seja pela internalização seja pela dominação estrutural e subordinação hierarquicamente imposta. Em sua concepção, os parâmetros reprodutivos do sistema capitalista são assegurados pela internalização.

Esse sistema de internalização precisa então ser confrontado em todas as suas dimensões e substituído por práticas educacionais que permitam aos educadores e estudantes suscitar mudanças para a construção de uma sociedade que não seja explorada pelo capital. A educação deve ir além do capital, possibilitando a transformação do trabalhador em um agente político, que pensa, que age e que usa a palavra como arma para transformar o mundo. É necessário romper com a lógica do capital na escola para, então, podermos vislumbrar a criação de uma alternativa educacional significativamente diferente.

Nesse mesmo sentido, Saviani (2012) ressalta que, apesar das reformas escolares ao longo dos tempos, o papel exercido pela escola tornou-se mais evidente: a reprodução da sociedade de classes e o reforço ao modo de produção capitalista. Assim, o conteúdo que a escola transmite é todo 
baseado em um conjunto de saber condizente com as necessidades da classe privilegiada. Conhecimentos estes que a classe dominada não tem acesso.

Apesar de haver um discurso da classe dominante que defende a superação da marginalidade pela escola, enfatizando a igualdade de oportunidades e fomentando a ideia de ascensão social, tais argumentos não passam de ilusões, afinal a escola apenas reproduz as relações sociais (SAVIANI, 1982).

Podemos identificar que tanto Mezsários quanto Saviani concebem a escola com função transformadora da sociedade. Para o primeiro, a escola deve orientar-se pela única perspectiva que ele considera viável: romper com a lógica do capital, visto que tal fato configura-se até mesmo no interesse da sobrevivência humana.

Para Saviani (2012), a escola se apresenta como um fator de marginalização e não como um instrumento de equalização social, pois converte os trabalhadores em marginais, à medida que intenta excluir dessa equalização todos aqueles que ingressam no sistema de ensino. Em sua perspectiva, a educação promoveria a transformação social ao confrontar a divisão de classes e a existência de interesses opostos.

\section{Abordagem metodológica}

Segundo Kozel (2005), as pessoas constroem sentidos sobre espaços ou coisas tanto pela atividade consciente quanto pelo conhecimento intuitivo, que perpassa suas expressões. Desse modo, os mapas mentais são instrumentos que possibilitam a construção de ideias, percepções e situações diversas, através da expressão gráfica, compreendendo as imagens como uma possibilidade de leitura dos valores humanos, uma vez que podem ser inseridos no contexto das representações que advêm do simbólico, de modo que perpassam por construções mentais decorrentes da apreensão de significados, que raramente são revelados pela razão.

Nessa perspectiva, os mapas mentais possibilitam apreender os sentidos sobre o espaço vivido e percebido, bem como a expressão cultural e social e todo o sistema de relações presentes nas vivências de cada ser humano. 
Assim, para realizarmos a pesquisa, recorremos à metodologia de mapas mentais, que consiste na representação, expressada por um desenho em uma folha de papel, acerca de determinada questão.

No trabalho que desenvolvemos, a questão posta aos estudantes brasileiros, haitianos e bolivianos foi: "O que é a escola para você" Para a realização da tarefa, foram disponibilizados aos estudantes alguns materiais de desenho, entre os quais: folha de papel, lápis de cor, canetas hidrográficas, lápis preto etc. $\mathrm{O}$ tempo estipulado para a confecção dos mapas mentais foi 50 minutos. A maioria dos estudantes desempenhou a atividade sem dificuldades, concluindo os desenhos mesmo antes do término do tempo disponível.

Foram aplicados mapas mentais nos três países. No Brasil, participaram da pesquisa estudantes de escolas situadas nos municípios de Porto Velho e Guajará-Mirim. Na Bolívia, os estudantes de uma escola na cidade de Guayaramerín e no Haiti, os colaboradores foram alunos de uma escola nos arredores de Porto Príncipe.

Apesar da dimensão da pesquisa, apresentaremos aqui apenas um recorte da aplicação dos mapas na cidade de Guajará-Mirim, que teve a participação de 21 estudantes com idade entre 14 e 16 anos que cursavam do $8^{\circ}$ ano do ensino fundamental ao $2^{\circ}$ ano ensino médio de uma escola pública. Do total de mapas elaborados, foram selecionados cinco por apresentarem características semelhantes de representação da escola.

A interpretação dos mapas mentais foi realizada de acordo com as fases propostas pela Metodologia Kozel (2009):

1 - Interpretação quanto à forma de representação dos elementos na imagem - este é o primeiro quesito a ser analisado quando se faz a leitura dos mapas, observando-se a diversidade de formas representativas. Os elementos propostos pela autora são os seguintes:

- Ícones: formas de representação gráficas através de desenhos;

- Letras: palavras complementando as representações gráficas;

- Mapas: forma de representação cartográfica que evidencia a espacialização do fenômeno representado; 
2 - Interpretação quanto à distribuição dos elementos na imagem - nesse quesito devem-se observar os seguintes aspectos:

- Representação da imagem em perspectiva

- Representação da imagem em forma horizontal

- Representação da imagem em forma circular

- Representação da imagem de maneira dispersa

- Representação de imagens isoladas

3 - Interpretação quanto à especificidade dos icones: esse item requer uma análise mais detalhada, pois evidencia aspectos mais complexos, visto que apresenta um universo permeado pelo simbólico em que perpassam vários elementos para a composição das imagens. Kozel (2005) indica os seguintes grupos de classificação

- Representação dos elementos da paisagem natural

- Representação dos elementos da paisagem construída

- Representação dos elementos móveis

- Representação dos elementos humanos

4 - Apresentaçôes de outros aspectos ou particularidades - nesse item a metodologia desenvolvida por Kozel propõe o levantamento e a análise de mensagens veiculadas pelos mapas mentais como textos a serem desvendados.

\section{A escola na perspectiva dos estudantes}

Apresentaremos a seguir a análise dos mapas mentais, os quais foram selecionados por evidenciarem, entre outros aspectos, ideias relacionadas à função da escola, o que nos possibilitou ainda estabelecer os seguintes grupos temáticos:

- Escola como perspectiva de futuro melhor e ascensão social

- Escola para capacitar para uma profissão

- Escola como espaço de interação

A Figura 1 foi elaborada por Rosa, uma adolescente de 14 anos, estudante do ensino fundamental. 
Quanto à forma de representação dos elementos na imagem, presentes na figura, foram encontrados ícones e letras com o intuito de expressar um diálogo, no qual ambos se complementam, de modo que auxilie na interpretação da figura. Pode-se dizer que, para Rosa, a escola tem papel fundamental na construção de um futuro, especificamente em relação à profissão. Com a distribuição dos elementos de forma horizontal, têm-se os elementos naturais que são os pássaros e as nuvens, e a presença de humanos interagindo. Dessa forma, o ambiente escolar é visto como um espaço de interação e vivências naturais. Para a aluna, a escola é o meio pelo qual garante um futuro, na perspectiva de "futuro brilhante", como ela expressa na mensagem "Eu Rosa vejo a escola como o melhor método de ter um futuro brilhante. Somente os estudos nos levam a um futuro adequado. A escola é a base, aonde sempre vamos conviver com o que aprendemos.".

\section{Figura 1 - Rosa, 14 anos}

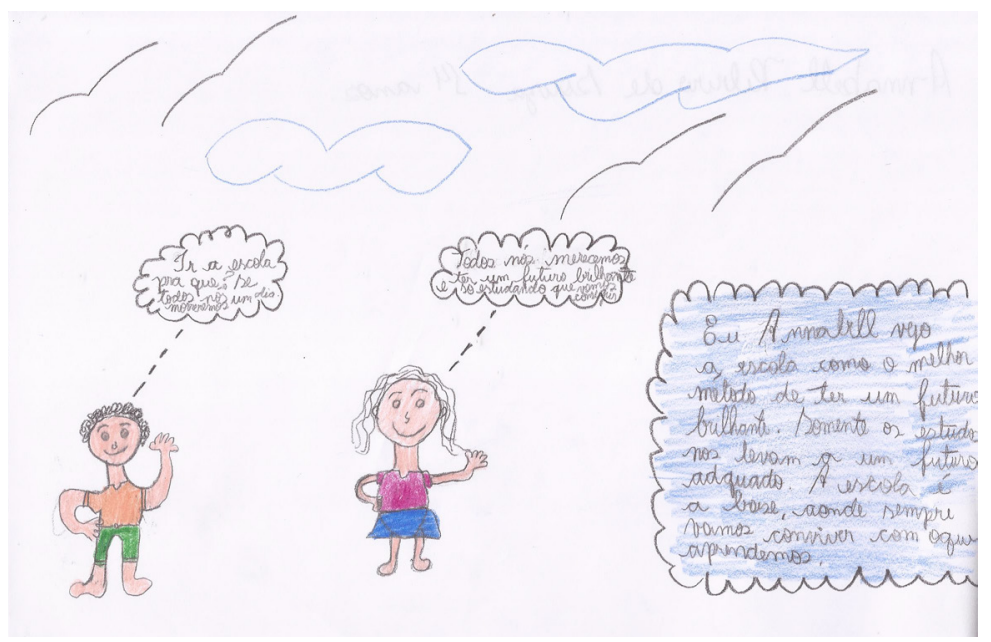

Fonte: Coleta de dados. Projeto Geopedagogia. CNPq, ciclo 2014-2015

$\mathrm{Na}$ representação elaborada por Girassol (Figura 2), uma adolescente de 16 anos, observa-se o predomínio de ícones, mas há presença de letras, com a intenção de propor maior facilidade de intepretação ao leitor. Quanto à distribuição, os elementos estão devidamente organizados e com vista aérea. Predominam elementos de paisagem natural como: árvore, nuvem, pássaros e ruas; construída como: casa e prédio escolar; e 
humanas como: mãe, pai, irmão e colegas de escola. A discente vê a escola como um espaço de múltiplas aprendizagens e preparação para o futuro, como afirma: "A escola pra mim é meu cotidiano, meu futuro! Envolvendo a naturalidade, um mundo novo, conhecer pessoas novas, e aprendendo a viver e enfrentar as dificuldades!". Assim, pode-se dizer que a escola para Girassol é um lugar de inúmeras experiências na qual ocorrem trocas e afetividade.

Figura 2 - Girassol, 16 anos

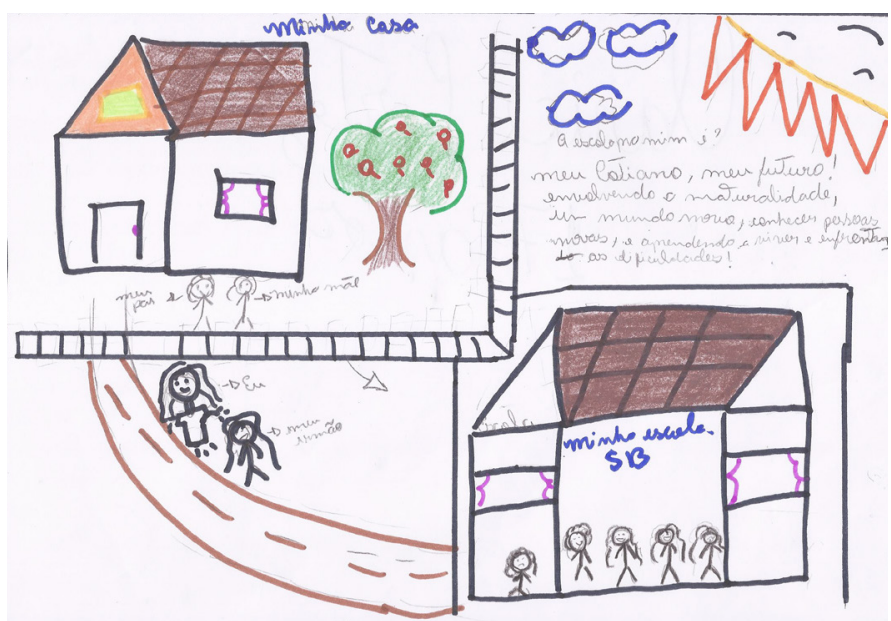

Fonte: Coleta de dados. Projeto Geopedagogia. CNPq, ciclo 2014-2015

A Figura 3 sugere a representação de um olhar e um sentimento mais profundo do espaço escolar. A estudante Violeta, de 16 anos, destaca os elementos de acordo com suas especificidades, não apenas ilustra, mas manifesta em sua fala a preocupação com a conservação da escola, que considera ser sua segunda casa e um lugar de aprendizagem, conjectura que, após a etapa escolar, poderá ter em mente uma profissão. Faz menção sobre a preservação da natureza, e as figuras de brinquedos, como o balanço, representam a escola como um espaço de diversão. Além disso, a participante cita a escola como um lugar de construção de amizades, de desenvolver afetividade, e deixa explícito o seu apoio à educação inclusiva. De forma simplificada, toda essa expressão ilustrada atende a perspectiva de evolução humana em todos os seus aspectos sociais. 
Figura 3 - Violeta, 16 anos

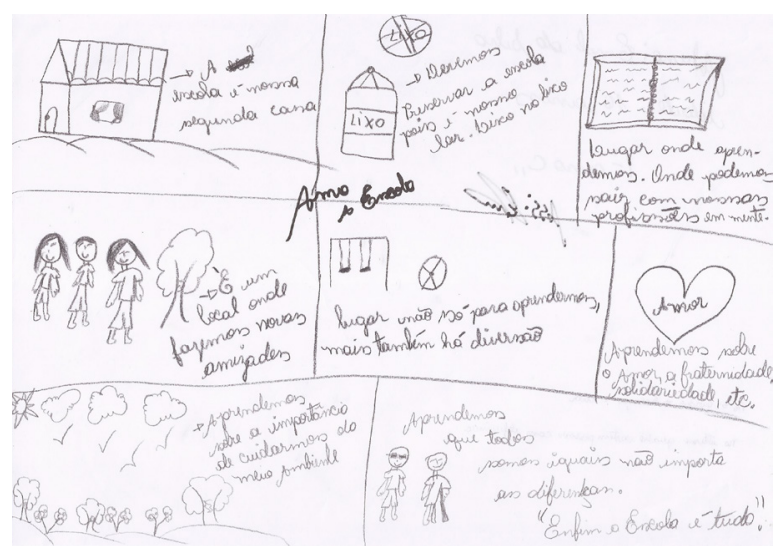

Fonte: Coleta de dados. Projeto Geopedagogia. CNPq, ciclo 2014-2015

Na produção de Margarida (Figura 4), 16 anos, é possível identificar dois momentos de análise. O primeiro representa os livros como sendo o intermediário entre a estudante e o conhecimento. $\mathrm{Na}$ fala, a escola é representada como parte principal da sua vida, por vê-la como o segundo espaço onde passa a maior parte do tempo. No segundo momento, temos a figura de uma paisagem natural, na qual se faz presente os elementos casa e carro. Evidentemente, esses elementos representam a estabilidade financeira relatada em sua fala sobre "subir na vida", predominando uma perspectiva de que, através da escola, futuramente é possível a ascensão social.

Figura 4 - Margarida, 16 anos

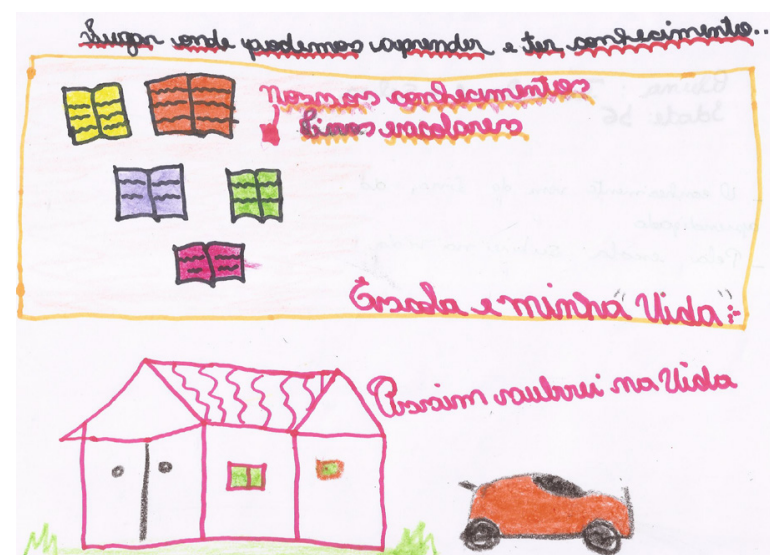

Fonte: Coleta de dados. Projeto Geopedagogia. CNPq, ciclo 2014-2015 
A representação de Cravo, 14 anos, apresenta apenas dois componentes, professor e aluno (Figura 5). Com exclusividade, o participante valoriza o professor como um mediador que transfere conhecimento, considerando a sua importância em sala de aula por estimular a aprendizagem. No destaque da fala do participante "a escola é um meio de educação, sem ela não existiria a profissão", a educação é vista como uma das vias para alcançar uma profissão e atender as demandas da inserção no mercado de trabalho.

Figura 5 - Cravo, 14 anos.

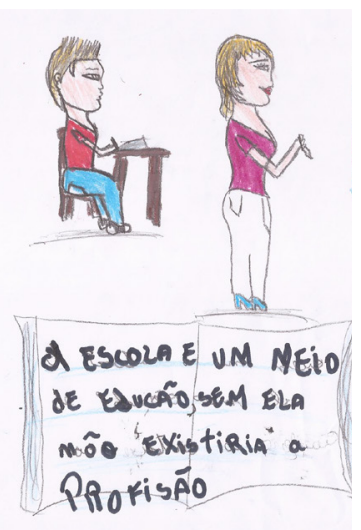

Fonte: Coleta de dados. Projeto Geopedagogia. CNPq, ciclo 2014-2015

Ao analisar os mapas, observa-se que a percepção dos estudantes acerca da escola ainda não difere da concepção que se tinha no século XVI: a preparação para exercer um ofício. Esses fatos estão bem explícitos, principalmente nas figuras 1,2 e 5, nas quais os mapas se referem à escola como aquela que irá prepará-los para uma profissão. É interessante observar, ainda, a presença da concepção da escola como um meio para a ascensão social, explicitada na Figura 1, como "futuro brilhante", e na Figura 4, como um meio de proporcionar estabilidade financeira mediante a possibilidade de "subir na vida".

De um modo geral, as respostas acerca do que é a escola parecem confirmar as afirmações de Saviani (1982; 2012) e Mészáros (2005) sobre a função da escola, que é a reprodução da sociedade de classes e o reforço ao modo de produção capitalista. 
Ainda que em algumas figuras seja possível identificar a concepção da escola relacionada à aprendizagem que se constitui mediada pelo professor (Figura 5), pelo livro (Figura 4), lugar de aprendizagem para a vida (Figura 3) e um lugar de múltiplas aprendizagens, inclusive para enfrentar as dificuldades da vida (Figura 2) é predominante a ideia de que o propósito do conhecimento adquirido na escola esteja a serviço da máquina produtiva.

Conforme discutido por Mészáros (2005), essa concepção do que é a escola se constitui pela internalização, pois as classes dominantes impõem uma educação para o trabalho alienante, que se mantém pela transmissão de valores que legitimam os interesses da classe dominante.

No entanto, é possível vislumbrar uma luz ao fim do túnel, ao identificar em algumas figuras a ideia da escola como um espaço de interação e de construção de relacionamentos, de formação do ser humano. A Figura 3 apresenta essa característica ao demonstrar preocupação com a conservação da escola e do meio, além de ser um lugar para todos, ao fazer alusão à educação inclusiva.

\section{Considerações finais}

Analisar a escola em contextos e perspectivas diferentes parece nos conduzir a dois caminhos: "o que a escola deveria ser" e outro "o que a escola é". Tais caminhos parecem surgir também quando a representação da escola vem de um dos seus principais atores: o estudante.

A análise dos mapas nos leva a perceber que muitos estudantes não buscam a escola com o intuito de crescer intelectualmente, de adquirir um saber a ser aplicado na transformação social, mas sim com o objetivo de ingressar no ensino superior ou técnico para obter uma profissão que possibilite a inserção no mercado de trabalho, além de estabilidade financeira e aquisição de bens materiais. A perspectiva sobre o que é a escola sugere que ela se constitui pela internalização de valores que legitimam os interesses e concepções do sistema capitalista. 
Diante disso, corre-se o risco de cada vez mais identificarmos analfabetos diplomados, cidadãos alienados submetidos a toda ideologia capitalista que, em vez de transformarem a sociedade, apenas reproduzem os parâmetros do sistema vigente.

\section{Referências}

FERREIRA JÚNIOR, A. História da Educação Brasileira: da Colônia ao século XX. São Carlos: EdUFSCar, 2010.

KOZEL, S. Comunicando e representando: Mapas como construções socioculturais. In: SEEMANN, Jörn (Org.). A aventura cartográfica: perspectivas, pesquisas e reflexões sobre a cartografia humana. Fortaleza: Expressão Gráfica e Editora, 2005.

KOZEL, S. As linguagens do cotidiano como representações do espaço: uma proposta metodológica possível. In: ENCUENTRO DE GEÓGRAFOS DA AMÉRICA LATINA: caminando en una américa latina en transformación, 2, 2009, Montevideo. Anais.... Montevideo: Universidad de la República, 2009, CD-ROM. ISBN: 978-9974-8002-8-1.

MÉSZÁROS, I. A Educação para além do capital. Tradução de Isa Tavares. São Paulo: Boitempo, 2005. 


\title{
7. A ESCOLA E O PROCESSO DE HUMANIZAÇÃO DO ESTUDANTE
}

\author{
Beatriz Lima Costa' \\ Iracema Neno Cecilio Tada² \\ Luanna Freitas Johnson ${ }^{3}$
}

\section{Introdução}

A Declaração Universal dos Direitos Humanos (1948) institui a educação como um direito de todos os cidadãos. Assim, a educação se configura como uma ferramenta mais eficaz para o desenvolvimento das habilidades pessoais de cada um e a garantia de uma vida digna.

Brasil, Bolívia e Haiti são países signatários da Declaração e apresentam em suas respectivas constituições os princípios nela postulados. Sendo assim, têm a educação como um direito de todos.

A Constituição da Bolívia (2009) declara que um dos objetivos e funções do país é a garantia ao cidadão de receber educação em todos os níveis de maneira universal, produtiva, gratuita, integral e intercultural, sem discriminação. No Haiti, a constituição de 1987 reconhece o direito ao progresso, informação, educação, saúde, trabalho e lazer para todos os cidadãos. A Constituição brasileira (1988) também proclama a educação como um direito de todos.

O reconhecimento da educação como um direito de todos e dever do Estado pode ser destacado como semelhança entre esses países. No entanto,

\footnotetext{
${ }^{1}$ Mestre em Psicologia pela Universidade Federal de Rondônia

${ }^{2}$ Doutora em Psicologia pela Universidade de São Paulo. Professora-associada do curso de Psicologia e do Programa de Pós-Graduação em Psicologia da Universidade Federal de Rondônia.

${ }^{3}$ Doutoranda em Educação (Dinter UEM/UNIR). Professora no Departamento Acadêmicos de Ciências da Educação na Universidade Federal de Rondônia - Campus de Guajará-Mirim.
} 
não é nosso objetivo tecer comparações e/ou análises sobre esse tema. Reportar-nos-emos a uma análise apenas da educação no cenário brasileiro, haja vista que, nos demais capítulos da presente obra, são apresentadas as peculiaridades da educação tanto na Bolívia quanto no Haiti. Dessa forma, convidamos o leitor a elaborar suas próprias reflexões comparativas sobre a educação entre os três países discutidos neste livro.

O artigo 205 da Constituição Federal Brasileira (1988) proclama que a educação visa ao pleno desenvolvimento da pessoa, seu preparo para o exercício da cidadania e sua qualificação para o trabalho. No entanto, em nossa prática em instituições escolares, é comum ouvirmos estudantes, pais e educadores destacarem a importância de frequentar a escola para ter sucesso na vida, valorizando a conquista do diploma para que a pessoa consiga, no futuro, um bom emprego e, consequentemente, a ascensão social. Tal compreensão nos remete a 170 anos atrás, quando a escola foi assim configurada pela classe trabalhadora "nos países capitalistas liberais, estáveis e prósperos”, como bem nos conta Maria Helena de Souza Patto (1996, p. 25).

Diante dessa realidade, questionamos: ter um diploma assegura a ascensão social em uma sociedade como a nossa, capitalista, desigual, com políticas educacionais que priorizam índices de matrícula e aprovação a qualquer custo, sem que o estudante de fato tenha se apropriado do saber escolar? Recorremos novamente a Patto (2005, p. 99) para denunciar a farsa da educação de bases capitalistas que insiste em assegurar a relação entre escolaridade e empregabilidade, desconsiderando que "é cada vez maior o número de analfabetos diplomados, não sem a ilusão de que conseguirão emprego e ascensão social".

A função da escola não é apoiar a ilusão vendida pelo sistema econômico capitalista, que mercantiliza a educação, incentiva formação relâmpago com a promessa de que o mercado de trabalho absorverá a mão de obra, dita qualificada. Sua função vai muito além disso, pois está diretamente responsável pela humanização do indivíduo por meio de uma prática pedagógica intencional, que deveria promover o desenvolvimento psíquico do estudante, tema que abordaremos neste capítulo. 


\section{A função da escola}

Reportando-nos a Duarte $(2004 ; 2007)$ temos que a função da escola é a socialização do saber escolar, ou seja, do conhecimento científico, produzido historicamente pelo homem, como a escrita, a leitura, a matemática, as Ciências Naturais e Sociais. Mas, para que a criança aprenda a ler e escrever, é preciso a elaboração de um currículo organizado em "atividades nucleares desenvolvidas pela escola”, como enfatiza Saviani (2003, p. 16), ao criticar o excesso de atividades extracurriculares, dissociadas das atividades curriculares, que vêm sendo desenvolvidas na escola, desvalorizando o acesso ao saber erudito que atenda as necessidades cognitivas do estudante.

Para tanto, os conteúdos curriculares devem estar organizados "na compreensão empírica dos fenômenos", objetivando o desenvolvimento do pensamento teórico, e não a memorização mecânica desprovida de significado e sentido para o estudante (ASBAHR, 2016, p. 176). Além disso, o ato de ensinar, como discute Facci (2007, p. 147), deve ser "uma ação planejada e consciente que influencia o desenvolvimento psicológico" do estudante, o desenvolvimento de suas funções psicológicas superiores como: a atenção voluntária, a memória lógica, a formação de conceitos, o raciocínio abstrato, entre outras funções fundamentais, para que o discente possa compreender criticamente a sociedade na qual se encontra inserido, não se sujeitando às relações de poder que o alienam.

Para que o ato pedagógico seja intencional, é importante que o professor, em parceria com a comunidade escolar, elabore, o projeto político-pedagógico da escola, pois esse importante documento, quando construído coletivamente, viabiliza a "transformação da realidade escolar na medida em que possibilita a discussão acerca dos problemas escolares e direciona as finalidades e ações educativas” (ASBAHR, 2006, p.81). $\mathrm{O}$ projeto, portanto, deveria ser construído, coletivamente, pelo corpo docente, comunidade, direção, pois é um momento que promove debate e reflexão sobre o fazer pedagógico, a construção da identidade da instituição de ensino, e a finalidade da escola e da educação na vida de seus alunos. 
Mas não podemos nos esquecer de que, no Brasil, os currículos nacionais apresentam uma perspectiva construtivista, perspectiva essa que desvaloriza o ato pedagógico intencional, colocando a figura do professor em segundo plano. Patto (2005, p.20) explana muito bem a desvalorização do educador ao destacar que "o construtivismo define o aluno como sujeito de seu desenvolvimento, como agente de seu processo de aprendizagem, como construtor do conhecimento". Essa concepção do estudante como o maior responsável por seu desenvolvimento e aprendizagem é cruel, mas se encaixa perfeitamente na sociedade capitalista da qual fazemos parte, contribuindo para uma compreensão equivocada quanto ao fracasso ou sucesso escolar, ao atribuir a exclusiva responsabilidade ao aluno, reforçando, assim, a competição que o mercado impõe, fazendo valer a divisão de classes e o fenômeno da meritocracia.

Além desse processo de alienação, as políticas educacionais brasileiras são elaboradas fora dos muros da escola, por parlamentares que muitas vezes não conhecem a realidade escolar. Patto $(2005$, p.26) relata que muitas ações são impostas à escola, de maneira vertical, sem a participação dos que vivem seu dia-a-dia e são tragados por novas diretrizes a cada mudança de governo, que "manipula sintomas, deixando intocadas suas causas estruturais", com os problemas da educação tratados superficialmente, sem buscar verdadeiramente uma solução que não culpabilize o estudante e promova educação de qualidade em prol do desenvolvimento humano e social.

Outro aspecto importante para se analisar no processo de implementação das políticas educacionais refere-se às propostas de formação continuada. A maioria das formações ofertadas a partir das instâncias superiores segue o modelo vertical e, não raro, apresentam modismos descartáveis ou teorias distantes da realidade vivida pelos educadores. Assim como as políticas públicas, as formações para professores são pensadas fora do contexto pessoal, cultural, histórico e socioeconômico do educador. Acerca desse ponto Souza (2006 p. 238) destaca que:

Observa-se, portanto, nas políticas públicas uma ausência de mecanismos que pudessem contar com a participação da experiência e 
da história profissional e política daqueles que fazem o dia-a-dia da escola, que lutam para sua construção, que optaram pela educação enquanto projeto político emancipatório e considerando as particularidades de bairros, municípios e contextos sociais.

Os efeitos desse processo, como analisa Patto (2008), decretam o adoecimento e a morte do educador, pois lhe furtam a autonomia e o sentido pessoal. Isso torna o trabalho pedagógico dificíl, pois, segundo Duarte (2007), pois, se o educador faz o seu trabalho de forma automática e alienada, reproduzirá nos estudantes essa mesma realidade. Portanto, a educação deve ser a chave para as mudanças sociais que desejamos, já que é por meio de uma pedagogia consciente, que tem seus objetivos traçados, que podemos fazer uma revolução.

Para Saviani (2009, p. 150), uma das questões que contribuem para o trabalho docente alienado é a realidade dos professores no Brasil, pois, geralmente recebem uma formação que prioriza os "conteúdos culturaiscognitivos", que secundarizam as exigências pedagógicas. Tal situação resulta em professores com muito conhecimento em suas áreas específicas, mas com pouca didática para ensinar.

Além disso, temos que considerar que a profissão de professor é desvalorizada em nosso país, razão pela qual devemos adicionar ao problema da formação docente "as questões do salário e da jornada de trabalho" (SAVIANI, 2009, p.153). O primeiro sempre baixo e a jornada excessiva resultam na falta de planejamento das aulas que, somada às péssimas condições de trabalho - salas superlotadas, muitas vezes apresentando problemas em sua infraestrutura - configuram "um grande sinal da desvalorização do trabalho do professor. $O$ trabalho, fator central da humanização, tornava-se assim elemento de degradação e sofrimento” (ASBAHR, 2006, p.107) que acaba por desestimular pessoas que um dia pensaram em se tornarem professores, e mesmo os que estão em exercício não sentem prazer em sua atividade profissional.

Porém, é necessário um olhar crítico para compreender que muitas questões políticas, sociais, econômicas, entre outras, atravessam o atual 
cenário de produção do fracasso que envolve a escola, não podendo culpabilizar o discente e o docente,

[...] não basta somente a força de vontade individual dos professores para a superação da alienação. Esta acontece em bases objetivas, que devem ser construídas na luta dos docentes e da sociedade civil em coletividade por uma educação pública de qualidade, o que inclui a criação de condições históricas para que o processo de superação da sociedade capitalista possa ser desencadeado. (ASBAHR, 2006, p. 112)

Saviani (2009, p.153) analisa que a nossa cultura capitalista ocidental prega que a educação desempenha uma "importância decisiva" em nossas vidas, ela que nos proporciona um emprego, uma posição produtiva na sociedade, gerando poder de compra, portanto, status, mas ao mesmo tempo as "políticas predominantes se pautam pela busca da redução de custos, cortando investimentos", ou seja, é um discurso contraditório. Entende-se a educação como pilar para uma sociedade humanizada, mas não se investe nela, por quê?

$\mathrm{Na}$ sociedade capitalista, se dividirmos de maneira grosseira, podemos dizer que aquele que explora e o que é explorado "defrontam-se no mercado proprietário aparentemente iguais, mas de fato desiguais, realizando, sob a aparência da liberdade, a escravização do trabalho ao capital" (SAVIANI, 2013, p.26). De fato, explorado e explorador pertencem a uma sociedade de classes, com interesses distintos, onde quanto menos consciência o trabalhador tiver, mais seguirá o que está posto, por não ter acesso a uma educação de qualidade para auxiliá-lo na reflexão para além do fazer cotidiano, não lhe possibilitando opor-se à submissão do opressor, para lutar contra o sistema e as políticas empregadas.

Diante desse desejo de mudança, Saviani (2013, p. 26) afirma que:

[...] a educação é um ato político significa dizer que a educação não está divorciada das características da sociedade; ao contrário, ela é determinada pela sociedade na qual está inserida. E, quando a sociedade é dividida em classes cujos interesses são antagônicos, a educação serve a 
interesses de uma ou de outra das classes fundamentais. Ora, no caso da pedagogia histórico-crítica, uma de suas características fundamentais é que ela se posiciona claramente a favor dos interesses dos trabalhadores, isto é, da classe fundamental dominada na sociedade capitalista. Daí, seu caráter de pedagogia contra hegemônica inserindo-se na luta pela transformação da sociedade atual.

É uma luta diária, que busca por meio da educação desalienar o aluno, para que ele se torne um cidadão consciente da importância da educação como peça fundamental para a luta, para que todos tenham acesso a uma educação gratuita de qualidade, que não esteja em função dos governos, apenas emplacando números de aprovação, que findam por maquiar a verdadeira situação nacional da precariedade de nossa educação.

Segundo Saviani (2016, p.238), “em matéria de educação, nós nos defrontamos, no Brasil, com um imenso déficit histórico que se arrasta já por pelo menos cem anos"; o autor faz essa afirmação diante da taxa de analfabetismo em relação à população total em 1890, e a mesma comparação tomando os dados do censo de 1991, mostrando que "o número absoluto de analfabetos quadruplicou".

Essa triste realidade se mantém em virtude de as políticas educacionais não serem a prioridade nos planos orçamentários, e, em sua maioria, apresentam caráter de reparação imediata, que é necessário, todavia é mais importante compreender que todo o sistema precisa de uma reestruturação. Mas essa reestruturação necessita contar com a participação daqueles que estão verdadeiramente inseridos no cotidiano escolar, os professores, a equipe técnica, a comunidade escolar.

\section{O que está por trás das políticas educacionais}

A realidade brasileira em relação à criação de políticas educacionais está diretamente relacionada com o cenário internacional, por depender do que é acertado em convenções e acordos em nosso mundo globalizado. Nessas negociações, o objetivo é a formação do chamado capital humano, uma mão de obra minimamente qualificada, sem formação que lhe permita 
questionar o sistema e a exploração à qual está submetido. Nesse sentido, Kassar (2011) destaca que incentivos fiscais de órgãos como o Banco Mundial para os países necessitados direcionam as políticas e os debates educacionais.

Blasco (2002) e Kassar (2011) denunciam os números apresentados pelo governo para garantir os investimentos, e isso quer dizer que o governo brasileiro não está buscando uma educação transformadora para a emancipação de nosso estudante, mas sim objetiva apenas cumprir as normas estipulas por entidades estrangeiras:

Há cerca de duas décadas, organismos multilaterais como o Banco Mundial (BM), a Organização das Nações Unidas para a Educação, a Ciência e a Cultura (UNESCO), a Organização Mundial de Comércio (OMC) e a Organização para Cooperação e o Desenvolvimento Econômico (OCDE) têm orientado as políticas educacionais nos países periféricos com o objetivo de responder, dentro dos limites do campo educacional e de sua possibilidade de alcance, à crise estrutural do capitalismo desencadeada nos anos de 1970, uma vez que a educação passou a ser vista não somente como uma importante fronteira econômica a ser explorada, mas também por sua funcionalidade aos grandes capitalistas em formar uma nova geração de trabalhadores que pudessem se adequar, em termos de conhecimentos e técnicas, às novas exigências produtivas e organizacionais. (MOTA JUNIOR; MAUÉS, 2014, p. 1139)

Portanto, as políticas educacionais estão intimamente ligadas a essas estratégias de suprir o mercado e às pressões do capital estrangeiro para apresentar números positivos, a qualquer custo.

Como exemplo de medidas tomadas para contornar o déficit na educação, temos a Lei no 11.114, de 16 de maio de 2005 (BRASIL, 2005) que "Altera os arts. 6o, 30, 32 e 87 da Lei no 9.394, de 20 de dezembro de 1996, com o objetivo de tornar obrigatório o início do ensino fundamental aos seis anos de idade", e a Lei no 11.274, de 6 de Fevereiro de 2006 (BRASIL, 2006) que "Altera a redação dos arts. 29, 30, 32 e 87 da Lei no 9.394, de 
20 de dezembro de 1996, que estabelece as diretrizes e bases da educação nacional, dispondo sobre a duração de 9 (nove) anos para o ensino fundamental, com matrícula obrigatória a partir dos 6 (seis) anos de idade”. Essas Leis incluíram a pré-escola como uma das etapas obrigatórias da educação básica, assim como incluíram o $9^{\circ}$ ano no ensino fundamental, determinando que as crianças com seis anos de idade iniciem a educação formal.

Segundo Martins e Facci (2016), a idade inicial para o ensino fundamental de seis anos acompanha a tendência mundial, mas o ensino precisa ser revisto, visto não ser a solução para os problemas da educação que as crianças comecem mais cedo, sem uma melhor integração entre a pré-escola e o ensino fundamental. É necessário que os educadores levem em consideração a atividade guia ${ }^{4}$ de cada período do desenvolvimento infantil para nortear sua prática pedagógica, a fim de que mudanças significativas ocorram no psiquismo do estudante. Tais mudanças só ocorrerão se o conhecimento erudito for apresentado com sentido, para ser apropriado pelo aluno.

Aquino e Albuquerque (2014, p. 67), ao desenvolverem uma pesquisa sobre o que os alunos do $2^{\circ}$ e $3^{\circ}$ ano do ensino fundamental pensam e sentem sobre a escola, verificaram que a maioria reportou positivamente sobre a hora do recreio. Quando questionadas sobre por que as crianças precisam ir para a escola, as respostas foram "aprender, ter expectativas para o futuro, brincar, benefícios da educação oferecidos pela escola, ter algo a fazer".

Em outra pesquisa realizada por Marques e Castanho (2011) com estudantes na faixa etária entre 10 e 13 anos, matriculados no Ensino Fundamental II de escolas públicas, com o objetivo de conhecer o sentido por eles atribuídos à escola, verificaram que a escola é importante, sendo promessa de um futuro digno, mas é vivida cotidianamente com aprendizagens não satisfatórias, aulas sem sentido, relações interpessoais desrespeitosas e sensação de cansaço, tanto por parte dos alunos quanto dos professores.

\footnotetext{
${ }^{4}$ Não iremos aqui discorrer sobre as atividades guia de cada período do desenvolvimento infantil, pois não é a finalidade deste capítulo. Para maiores informações sobre atividade guia, recomendamos a leitura de VIGOTSKII, L. S.; LURIA, A. R.; LEONTIEV, A. N. Linguagem, desenvolvimento e aprendizagem. 7.ed. São Paulo: Ícone, 2001.
} 
Tais resultados possibilitam perceber que, embora valorizada socialmente, a escola mostra dificuldades de cumprir o seu papel, ou seja, ela não dá conta de socializar o saber escolar para a humanização de seus estudantes.

Com relação ao ponto de vista sobre a escola e o processo de aprendizagem com alunos do ensino médio da rede pública, Fontes e Lima (2011) identificaram que os estudantes percebem a escola organizada de forma conteudista e descontextualizada de suas necessidades. O estudo possibilitou observar, ainda, que os alunos se autorresponsabilizam pelo processo de aprendizagem, atribuindo ao comportamento e às dificuldades pessoais os problemas escolares.

Podemos perceber que os estudantes - tanto dos anos iniciais quanto dos anos finais da educação básica brasileira - não entendem o verdadeiro sentido da escola em suas vidas, o que nos leva a configurar a instituição escolar como um espaço que culpabiliza, vitimiza e, por que não dizer, desumaniza o estudante.

\section{Considerações finais}

O panorama aqui traçado sobre a educação brasileira é preocupante por contribuir para embates em esferas diversas. No que tange às políticas educacionais, destaca-se a descontinuidade das ações propostas para o enfrentamento do fracasso escolar em cada troca de governo federal, estadual e municipal, propostas essas elaboradas por especialistas sem um diálogo com os profissionais que se encontram no cotidiano escolar, que têm muito a contribuir para a elaboração de estratégias que possam combater o fracasso escolar. Enquanto eles não forem ouvidos, políticas de correção de fluxo, mais educação, inclusão escolar, educação em tempo integral, entre outras, impostas, hierarquicamente, dificilmente contribuírão para o sucesso de nossa educação.

É preciso compreender que essas dificuldades não são do aluno, em função de supostos distúrbios de aprendizagem, e sim do nosso sistema educacional. Tal situação tem afetado negativamente, também, o professor, pois este é destituído da sua função - a de ensinar -, o que demonstra a 
desvalorização desse importante profissional que, além de não ter sua voz valorizada, não recebe remuneração digna de sua função.

Dessa forma, sem a compreensão dos propósitos da instituição escolar, a educação tem contribuído para a formação de indivíduos alienados, que buscam concluir o ensino médio (como também o ensino superior, que neste capítulo não foi abordado) a fim de ter um diploma, por acreditarem ser esse o passaporte para conseguirem um emprego que assegure sua ascensão social.

É preocupante a influência que as entidades internacionais desempenham no Brasil, com o incentivo financeiro internacional determinando as estratégias de educação adotadas pelo nosso governo. Essa postura reforça o status quo de uma sociedade de classes, pois busca a formação de mão de obra minimamente "qualificada", sem promover uma educação que forme cidadãos de fato humanizados. Podemos afirmar que tais parcerias têm sim contribuído para o sucateamento da educação brasileira, dificultando a realização de uma prática pedagógica intencional pelos docentes, com sentido e significado do conteúdo escolar, para seus alunos.

Para buscar uma solução para o cenário nacional é necessária uma reestruturação do sistema político e educacional, para que possamos obter resultados expressivos, passando pelas políticas educacionais e pela formação de professores, a fim de que possam atuar com uma prática intencional, que promova aprendizagem e mudanças na vida do estudante. É necessário, ainda, avançar no investimento em infraestrutra, resultando assim em uma educação pública de qualidade, que forme cidadãos críticos, capazes de aplicar os conteúdos científicos em seu dia-a-dia e de compreender seu papel no sistema capitalista e não se conformar com ele, assim transformando o que está posto, assumindo novas posturas e promovendo mudanças sociais mais igualitárias.

\section{Referências}

AQUINO, F. S. B.; ALBUQUERQUE, J. A.. O que pensam as crianças sobre a escola?. In: GUZZO, R. S. L. (Org.) Psicologia Escolar: desafios e bastidores na educação pública. Campinas, SP: Editora Alínea, 2014, p.55 - 84. 
ASBAHR, F. S. F. Idade escolar e atividade de estudo: educação, ensino e apropriação dos sistemas conceituais. In: MARTINS, L. M.; ABRANTES, A. A.; FACCI, M. G. D. (Orgs.) Periodização Histórico-Cultural do desenvolvimento psíquico: do nascimento à velhice. Campinas, SP: Autores Associados, 2016. p. 171-192.

ASBAHR, F. S. F. Sobre o Projeto político-Pedagógico: (im) possibilidades de construção. In: VÍÉGAS, L. S.; ANGELUCCI, C. B. (Orgs.) Políticas públicas em educação: uma análise crítica a partir da Psicologia Escolar. São Paulo, SP: Casa do Psicólogo, 2006. p. $77-115$.

BLASCO, C. M. Producción y circulación del conocimiento en el campo de la política educativa y la gestión en América Latina. Santafé de Bogotá: Universidad Nacional de Colombia; Programa RED. p. 1-37.2002. Disponível em: <http://www.humanas.unal.edu. co/iipe/PoliticaEdAL\%20UNIIPE.pdf>. Acesso em: 10 out. 2018.

BOLIVIA. Constitución Politíca del Estado (CPE), 2009. Disponível em: http://www. oas.org/DIL/ESP/Constitucion_Bolivia.pdf. Acesso em: 10 abr. 2019.

BRASIL. Constituição da República Federativa do Brasil, 1988. Disponível em: http:// www.planalto.gov.br/ccivil_03/Constituicao/Constituicao.htm. Acesso em: 10 abr. 2019.

Lei n. $11.114,16$ de maio de 2005. Altera os Arts. 6º 30,32 e 87 da Lei n. 9.394, de 20 de dezembro de 1996, com o objetivo de tornar obrigatório o início do ensino fundamental aos seis anos de idade. Diário Oficial da União, Brasília, DF, 17 maio 2005. Disponível em: http:/www.planalto.gov.br/ccivil_03/_Ato2004-2006/2005/Lei/L11114. htm. Acesso em: 10 abr.2019.

Lei n. 11.274, 6 de fevereiro de 2006. Altera a redação dos Arts. 29, 30, 32 e 87 da Lei n. 9.394, de 20 de dezembro de 1996, que estabelece as diretrizes e bases da educação nacional, dispondo sobre a duração de 9 (nove) anos para o ensino fundamental, com matrícula obrigatória a partir dos 6 (seis) anos de idade. Diário Oficial da União, Brasília, DF, 7 fev. 2006. Disponível em: http://www.planalto.gov.br/ccivil_03/_Ato20042006/2006/Lei/L11274.htm. Acesso em: 10 abr. 2019.

DECLARAÇÃO UNIVERSAL DOS DIREITOS HUMANOS. Assembleia Geral das Nações Unidas em Paris. 10 dez. 1948. Disponível em: https://nacoesunidas.org/wp-content/uploads/2018/10/DUDH.pdf. Acesso em: 10 abr.2019.

DUARTE, N. Educação escolar, teoria do cotidiano e a escola de Vigotski. Campinas, SP: Autores Associados, 2007.

DUARTE, N. Vigotski e o "aprender a aprender": crítica às aproximações neoliberais e pós-modernas da teoria Vigtskiana. Campinas, SP: Autores Associados, 2004.

FONTES, D. C. LIMA, V. A. A. A escola segundo alunos do ensino médio de Porto Velho-RO. Revista Semestral da Associação Brasileira de Psicologia Escolar e Educacional, SP. v. 15, n. 1, p. 71-79, 2011. Disponível em: http://www.scielo.br/pdf/pee/v15n1/08.pdf. Acesso em: 11 out. 2018. 
FACCI, M. G. D. “Professora, é verdade que ler e escrever é uma coisa fácil?”- Reflexões em torno do processo ensino-aprendizagem na perspectiva vigotskiana. In: MEIRA, M. E.; FACCI, M. G. D. (Orgs.) Psicologia Histórico-Cultural: contribuições para o encontro entre a subjetividade e a educação. São Paulo. SP: Casa do Psicólogo, 2007. p. 135-156.

HAITI. La Constitution de la République D’Haïti, 1987. Disponível em: http://www.oas. org/juridico/mla/fr/hti/fr_hti-int-txt-const.html. Acesso em: 10 abr. 2019.

KASSAR, M. de C. M. Educação especial na perspectiva da educação inclusiva: desafios da implantação de uma política nacional. Educar em revista, Curitiba, n. 41, p. 61-79, 2011. Disponível em: <http://www.scielo.br/pdf/er/n41/05.pdf〉. Acesso em: 10 out. 2018.

MARQUES, P. B.; CASTANHO, M. I. S. O que é a escola a partir do sentido construído por alunos. Revista Semestral da Associação Brasileira de Psicologia Escolar e Educacional, SP. v. 15, n. 1, p. 23-33, 2011. Disponível em: http://www.scielo.br/pdf/pee/ v15n1/03.pdf Acesso em: 11 out. 2018.

MARTINS, J. C.; FACCI, M. G. D. A transição da educação infantil para o ensino fundamental: das jogos de papéis sociais à atividade de estudo. In: MARTINS, Lígia Márcia; ABRANTES, Angelo Antonio; FACCI, Marilda Gonçalves Dias (Org.) Periodização histórico-cultural do desenvolvimento psíquico: do nascimento à velhice. Campinas: $\mathrm{Au}-$ tores Associados, 2016. p. 149-170.

MOTA JUNIOR, W. P. da; MAUES, O. C.. O Banco Mundial e as Políticas Educacionais Brasileiras. Educ. Real., Porto Alegre , v. 39, n. 4, p. 1137-1152, 2014. Disponível em: $<$ http://www.scielo.br/scielo.php?script=sci_arttext\&pid=S2175-62362014000400010\&lng=pt\&nrm=iso $>$. Acesso em 10 out. 2018.

PATTO, M. H. S. A produção do fracasso escolar: histórias de submissão e de rebeldia. São Paulo, SP: T.A. Queiroz, 1996.

PATTO, M. H. S. Exercícios de indignação: escritos de educação e psicologia. São Paulo, SP: Casa do Psicólogo, 2005.

PATTO, M. H. S. Políticas atuais de inclusão escolar: reflexão a partir de um recorte conceitual. In.: BUENO, J. G. S.; MENDES, G. M. L.; SANTOS, R. A. Deficiência e escolarização: novas perspectivas de análise. Araraquara, SP: Junqueira \& Marin, Brasília, DF: CAPES, 2008. p. 25-42

SAVIANI, D. A pedagogia histórico-crítica, as lutas de classe e a educação escolar. Germinal: Marxismo e Educação em Debate, Salvador, v. 5, n. 2, p. 25-46, 2013. Disponível em: https://portalseer.ufba.br/index.php/revistagerminal/article/view/9697/7085. Acesso em: 10 out. 2018.

SAVIANI, D. Da LDB (1996) ao novo PNE (2014-2024): por uma outra política educacional. Campinas, SP: Autores Associados, 2016. 
SAVIANI, D. Formação de professores: aspectos históricos e teóricos do problema do contexto brasileiro. Revista Brasileira de Educação, v. 14, n. 40, p. 152-180, 2009. Disponível em: http://www.scielo.br/pdf/rbedu/v14n40/v14n40a12. Acesso em: 1º out. 2018.

SAVIANI, D. Pedagogia Histórico-Crítica: primeiras aproximações. Campinas, SP: Autores Associados, 2003.

SOUZA, M. P. R. Políticas Públicas e Educação: desafios, dilemas e possibilidades. In: ANGELUCCI, C. B; VIÉGAS, L. S. (Orgs.) Políticas Públicas e Educação: uma análise crítica a partir da Psicologia Escolar. São Paulo, SP: Casa do Psicólogo, 2006. p. 229-243. 


\title{
8. A EDUCAÇÃO ESCOLAR DE ALUNOS IMIGRANTES EM DISSERTAÇÕES E TESES BRASILEIRAS E PORTUGUEŚAS: O DESAFIO DA INCLUSÃO DAS DIFERENÇAS
}

\author{
Lineu Norio Kohatsu ${ }^{7}$ \\ Maria da Conceição Pereira Ramos² \\ Natália Ramos ${ }^{3}$
}

\section{Alguns dados introdutórios}

Brasil e Portugal, embora países historicamente vinculados, apresentam, hoje, realidades sociais com aspectos quantitativos e qualitativos distintos e algumas similaridades, além da língua.

No ano de 2017, a população brasileira passou de 207 milhões de habitantes ${ }^{4}$, com $2.099 .955^{5}$ estrangeiros residindo no país; os portugueses representam o grupo mais numeroso, com $270.615^{6}$ registros; $92.220^{7}$ é o número de registros ativos de bolivianos ${ }^{8}$.

\footnotetext{
${ }^{1}$ Professor do Instituto de Psicologia - Universidade de São Paulo. email: lineu@usp.br

${ }^{2}$ Professora da Faculdade de Economia - Universidade do Porto e CEMRI.cramos@fep. up.pt

${ }^{3}$ Professora Associada da Universidade Aberta de Lisboa e CEMRI. natalia@uab.pt ${ }^{4}$ http://www.brasil.gov.br/cidadania-e-justica/2017/08/populacao-brasileira-passa-de-207-7-milhoes-em-2017. Acesso em 23 de janeiro de 2018.

${ }^{5}$ Dados referentes a 16/01/2018, obtidos através do Sistema Eletrônico do Serviço de Informação ao Cidadão (e-SIC) da Polícia Federal.

${ }^{6}$ Dados referentes a 03/05/2016, obtidos através do Sistema Eletrônico do Serviço de Informação ao Cidadão (e-SIC) da Polícia Federal.

${ }^{7}$ Dados referentes a 16/01/2018, obtidos através do Sistema Eletrônico do Serviço de Informação ao Cidadão (e-SIC) da Polícia Federal.

${ }^{8} \mathrm{Na}$ matéria "Bolivianos se tornam a segunda maior colônia de estrangeiros em SP", publicada pelo jornal Folha de São Paulo, em 16/06/2013, os dados apontam que entre 2000 e 2010 foi registrado um aumento de 173\%, passando de 6.578 para 17.960 bolivianos, somente na cidade de São Paulo. O Consulado da Bolívia considera que o número possa ser cinco vezes maior, se contados os imigrantes ilegais, termo usado na matéria.
} 
Em virtude da presença significativa de imigrantes bolivianos no Brasil, especialmente na cidade de São Paulo, escolhido como o principal destino no país, o interesse pela temática da imigração boliviana vem crescendo no âmbito acadêmico (SILVA, 2006; CYMBALISTA E XAVIER, 2007; SOUCHAUD, 2010; BAENINGER, 2012).

Embora o Brasil não seja considerado um país com um fluxo migratório significativo, se comparado a outros países ${ }^{9}$, a questão migratória ganhou notoriedade, resultando inclusive em mudanças importantes na legislação, como a revogação do Estatuto do Estrangeiro, Lei no 6.815/1980, após a sanção da Lei de Migração no 13.445/2017, orientada por princípios de direitos humanos universais, estabelecendo garantias contra a xenofobia, discriminação e criminalização; acolhimento humanitário; igualdade de tratamento; inclusão social e laboral; entre outras garantias ${ }^{10}$.

A presença dos imigrantes tem sido registrada também na educação. Segundo o censo escolar de $2017^{11}$, foram registradas 32.499 .772 matrículas na educação básica, sendo 3.864.463 na pré-escola; 12.076 .354 no ensino fundamental anos iniciais; 9.915.294 nos anos finais; 6.643.661 no ensino médio; $74.826^{12}$ matrículas na educação básica eram de estrangeiros. Os grupos mais numerosos são representados pelos estudantes de nacionalidade boliviana (9.757 matrículas), estado-unidense (9.029), portuguesa (7.435), japonesa (5.840), paraguaia (5.253), argentina (3.437), espanhola (3.285), entre outros.

\footnotetext{
${ }^{9}$ Segundo a matéria "O Brasil tem pouco imigrante", publicada pela UOL, em 18 de agosto de 2018. No entanto, a matéria informa, com base na estimativa da Polícia Federal, 750 mil estrangeiros no país, número inferior ao obtido junto à $\mathrm{PF}$, conforme citado inicialmente.

${ }^{10}$ Sem desconsiderar a importância da Lei de Migração, é importante destacar que algumas garantias já estavam previstas na Constituição Federal de 1988 e no Estatuto da Criança e do Adolescente - ECA, que nortearam, por exemplo, a Resolução no 10, de 2 de fevereiro de 1995, da Secretaria da Educação de São Paulo, que dispunha sobre a matrícula de alunos estrangeiros na rede estadual de ensino, garantindo o direito ao acesso à escola pública e gratuita e impedindo qualquer forma de discriminação.

${ }^{11}$ http://www.brasil.gov.br/educacao/2017/09/mec-divulga-dados-preliminares-do-censoescolar-de-2017 Acesso em 23 de janeiro de 2018,

${ }^{12}$ Dados fornecidos pelo INEP via o Serviço de Informação ao Cidadão.
} 
No estado de São Paulo, segundo dados da Secretaria Estadual da Educação ${ }^{13}$, atualmente estão matriculados nas escolas estaduais 9,5 mil alunos estrangeiros, representando um aumento de $66 \%$ em relação ao ano de 2010, que registrava 5,7 mil alunos. São Paulo, capital do Estado, é a região com maior número de alunos de outras nacionalidades (5.636 matrículas), sendo 58\% de nacionalidade boliviana (3.281). Segundo dados da Secretaria Municipal de Educação de São Paulo ${ }^{14}$, atualmente existem 4.067 alunos imigrantes na Rede Municipal de Ensino, sendo aproximadamente $78 \%$ de origem latino-americana, de 17 nacionalidades. Os grupos mais numerosos são de nacionalidade boliviana (2.633 matrículas), paraguaia (123 matrículas), argentina (118 matrículas) e peruana (110 matrículas).

Em relação a Portugal, a população residente ${ }^{15}$, em 2016, era pouco superior a 10 milhões, tendo, aproximadamente, 3,9\% de estrangeiros residentes. Embora tradicionalmente um país de emigração, nos últimos anos a imigração tem aumentado significativamente em Portugal, assim como tem ocorrido em outros países da União Europeia e da OCDE (Organização para a Cooperação e Desenvolvimento Econômico), demandando políticas de recepção e acolhimento dos imigrantes, inclusive no âmbito educacional (RAMOS, 2008, p. 32-34).

No ano letivo de $2016^{16}$, estavam matriculados nos três ciclos do Ensino Básico (1º ao $9^{\circ}$ ano) 1.013.397 alunos e no Ensino Secundário

\footnotetext{
${ }^{13} \mathrm{http}: / /$ www.educacao.sp.gov.br/noticias/cresce-em-66-numero-de-estudantes-nascidos -fora-do-brasil-na-rede-estadual-de-sp/

${ }^{14}$ Dados publicados no Comunicado no 560, de 3 de maio de 2016, no Diário Oficial da Cidade de São Paulo, de 4 de maio de 2016, p. 40. Há, no entanto, uma pequena diferença com relação aos dados obtidos por outra fonte oficial. Conforme dados fornecidos pelo Sistema Eletrônico do Serviço de Informação ao Cidadão da Prefeitura Municipal de São Paulo - Escola Online, em fevereiro de 2016 estavam matriculados 2.441 alunos de origem boliviana. $\mathrm{O}$ número ligeiramente abaixo talvez possa ser explicado pela diferença dos períodos.

${ }^{15} \mathrm{https} / /$ www.pordata.pt/Portugal/Quadro+Resumo/Portugal-230616. Acesso em $23 \mathrm{de}$ janeiro de 2018.

${ }^{16}$ Há dados de 2017 disponíveis no site. https://www.pordata.pt/Portugal/Alunos+matriculados+total+e+por+n\%C3\%ADvel+de+ensino-1002. Mas foram mantidos os dados de 2016 para serem cotejados com o número de alunos estrangeiros, que foram obtidos no mesmo ano em outra fonte.
} 
391.538 alunos $^{17}$. Desses, 36.618 matrículas eram de alunos de nacionalidade estrangeira, sendo 6.232,11.101 e 9760, respectivamente, matriculados no $1^{\circ}, 2^{\circ}$ e $3^{\circ}$ ciclos do Ensino Básico, e 9.525 matriculados no Ensino Secundário. Os maiores grupos são originários dos Países Africanos de Língua Oficial Portuguesa - PALOPs (32,6\%), seguidos pelos imigrantes da América do Sul (27,3\%), da União Europeia (17,6\%), países do Leste Europeu (11,9\%), Ásia (6,7\%) e outros (4\%), conforme dados do Ministério da Educação (citados por Oliveira e Gomes, 2017). Os quatro países de maior procedência dos alunos estrangeiros são o Brasil (26,5\%, correspondendo a 9.687 alunos), Cabo Verde, Guiné-Bissau e Angola.

A presença de alunos de diferentes nacionalidades, línguas e culturas tem representado grandes desafios aos sistemas educacionais (RAMOS, 2008, 2013) que, historicamente, tiveram a função de difundir a língua oficial e contribuir para a constituição de uma identidade nacional, condição necessária para garantir a coesão dos estados nacionais modernos (ZANOTTI, 1972; ENGUITA, 1989).

Em Portugal, a escolarização de alunos imigrantes e de minorias étnicas foi discutida por pesquisadoras de referência (CASA-NOVA, 2005; RAMOS, N., 2007, 2008) e tornou-se tema cada vez mais presente em dissertações e teses.

No Brasil, mais recentemente, algumas coletâneas sobre a temática imigração-educação começaram a ser publicadas (BAHIA; SANTOS, 2016; MAZZA; NORÕES, 2016; RODRIGUES, 2017). Observa-se ainda que a presença significativa de alunos de origem boliviana nas redes públicas de ensino tornou-se objeto de investigação, conforme se pode ver em alguns artigos publicados (MAGALHÃES; SCHILLING, 2012; OLIVEIRA, 2014; CARVALHO, 2015; FREITAS; SILVA, 2015; SILVA; PINEZI, 2015; silva e outros, s.d.).

Com o intuito de contribuir para a divulgação da produção acadêmica recentemente realizada em algumas universidades no Brasil e em

17 https://www.pordata.pt/Portugal/Alunos+matriculados+total+e+por+n\%C3\%A Dvel+de+ensino-1002. Acesso atualizado em 21 de outubro de 2018. 
Portugal, neste trabalho serão apresentadas algumas dissertações e teses que tiveram como tema central a educação escolar de alunos imigrantes ${ }^{18}$.

\section{Procedimentos}

O levantamento de dissertações e teses foi realizado a partir das seguintes bases:

No Brasil:

- Sistema Unificado de Bibliotecas da Universidade de São Paulo

- Sistema de Publicação Eletrônica de Teses e Dissertações da Biblioteca Digital da PUC-SP

Em Portugal:

- Repositório Aberto - Universidade Aberta de Lisboa

- Catálogo - Universidade do Porto

- Coleção de Teses do Observatório das Migrações - Alto Comissariado para as Migrações - ACM

O levantamento foi realizado a partir do termo "imigração", sendo selecionadas, pela leitura dos títulos e dos resumos, as pesquisas relacionadas à educação.

Posteriormente, para composição do corpus deste estudo, foram adotados como critérios de inclusão-exclusão:

a) pesquisas relacionadas à educação escolar de imigrantes e minorias étnicas (Portugal);

b) relacionadas ao período mais recente, excluindo-se, portanto, as pesquisas históricas (relacionadas ao século XIX até meados do século XX);

c) pesquisas com texto integral disponível em formato digital e acessível pela internet.

Foram selecionados para o corpus deste estudo 32 títulos (dissertações e teses), sendo 12 pesquisas brasileiras realizadas na USP e na PUC e 20 pesquisas portuguesas realizadas na Universidade Aberta (Lisboa e

\footnotetext{
${ }^{18} \mathrm{O}$ levantamento de dissertações e teses fez parte do projeto de pós-doutorado realizado na Faculdade de Economia da Universidade do Porto, sob supervisão da Profa. Maria da Conceição P. Ramos e cossupervisão da Profa. Natalia Ramos.
} 
Porto), Universidade do Porto, Universidade de Coimbra e Universidade Nova de Lisboa.

É importante esclarecer que, embora a proposta inicial tenha sido limitar a análise à produção acadêmica da Universidade de São Paulo, Universidade Aberta e Universidade do Porto, foram incluídas as produções da Pontifícia Universidade Católica de São Paulo, pela relevância da produção, e da Universidade de Coimbra e da Universidade Nova de Lisboa, por constarem nas bases consultadas para a busca e, sobretudo, também pela relevância da produção.

No Brasil, embora se reconheça a relevância da produção de outras universidades sobre o tema da imigração, foi necessário estabelecer a delimitação do universo de estudo no conjunto das referidas universidades para a viabilidade deste trabalho.

A partir da constituição do corpus, foi realizada a leitura das dissertações e teses que orientou a sistematização e análise dos dados observados. :

$\mathrm{Na}$ primeira parte serão apresentados os estudos brasileiros e, na sequência, os estudos realizados em Portugal. Posteriormente serão apresentadas algumas comparações entre a produção dos dois países.

\section{DISSERTAÇÕES E TESES BRASILEIRAS}

A partir dos títulos encontrados pelo Sistema Unificado de Bibliotecas da Universidade de São Paulo através dos termos 'imigração' (193 títulos) e 'imigrantes' (64 títulos), foram selecionados 17 títulos referentes à imigração e educação e, destes, selecionados seis estudos relacionados estritamente à educação escolar.

No levantamento de teses e dissertações realizado por meio do Sistema de Publicação Eletrônica de Teses e Dissertações da Biblioteca Digital da PUC-SP ${ }^{19}$, a partir do termo 'imigração', foram encontrados 162 títulos, sendo selecionados seis títulos relacionados à imigração e educação.

Das dissertações e teses brasileiras, portanto, foram selecionados 12 títulos para o corpus deste estudo, sendo seis estudos realizados na

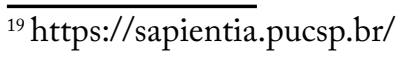


Universidade de São Paulo - USP (cinco dissertações de mestrado e uma tese de doutorado) e seis estudos realizados na Pontifícia Universidade Católica de São Paulo - PUCSP (cinco dissertações de mestrado e uma tese de doutorado).

Os estudos foram categorizados em seis grupos, tendo como critério o tema principal da investigação.

\section{a) Ensino e aprendizagem de português como língua estrangeira}

Quatro pesquisas investigaram o ensino e a aprendizagem da língua portuguesa por bolivianos. Três foram realizadas em escolas públicas, sendo duas em escolas de São Paulo (MANDALÁ, 2015; GABRIEL, 2016) e uma em escola no município de Guarulhos, região metropolitana de São Paulo (MOLINARI, 2016).

A pesquisa de Vieira (2010) foi a única realizada com adultos, fora do contexto de educação regular, tendo a prática docente da própria pesquisadora como objeto de investigação. A pesquisadora aponta a necessidade de discutir questões relacionadas a etnocentrismo, alteridade, preconceitos e xenofobia para sensibilizar professores e alunos, recomendando uma abordagem multicultural e atenção às características dos falantes de português e espanhol.

Mandalá (2015) analisou a produção textual de alunos do $8^{\circ}$ ano do ensino fundamental. Linguisticamente, buscou-se identificar o nível de domínio da escrita da língua portuguesa, verificar a visão de mundo e a imagem de si mesmos construídas por alunos brasileiros e bolivianos; situações de violência em que os alunos bolivianos são submetidos no ambiente escolar também foram discutidas. Foi possível constatar que alunos brasileiros e bolivianos atuam, linguística e culturalmente, ora de maneira distinta, ora de maneira similar. Para a pesquisadora, a perspectiva intercultural pode favorecer a interação e a dissolução de preconceitos.

Gabriel (2016) investigou as representações sociais dos professores de língua portuguesa e de aprendizes bolivianos em uma escola pública de São Paulo. A pesquisa destaca a complexidade do ensino de língua 
portuguesa e as dificuldades dos alunos estrangeiros, que não são percebidas ou ignoradas pelos "maus" professores, segundo a representação feita pelos alunos. Por outro lado, práticas com enfoque intercultural foram associadas à representação do "bom" professor pelos alunos.

$\mathrm{Na}$ tese de doutorado de Molinari (2016), a pesquisa foi realizada em duas escolas públicas de Guarulhos e investigou a escolarização e alfabetização de crianças bolivianas. Os resultados permitiram compreender a lacuna existente entre a política educacional e a escolarização e a alfabetização de imigrantes não falantes da língua portuguesa realizada pelas escolas.

\section{b) Interações entre imigrantes e brasileiros.}

Das três pesquisas encontradas, duas foram realizadas em escolas públicas de São Paulo (OLIVEIRA, 2013; ROSA, 2016) e uma em escola particular (SOARES, 2015).

A partir das observações realizadas nas salas dos $5^{\circ}, 6^{\circ}$ e $7^{\circ}$ anos do ensino fundamental, Oliveira (2013) destaca que a característica mais marcante nas interações entre alunos brasileiros e bolivianos foi o isolamento da maioria dos imigrantes, que pode ser entendido como recusa de contato por parte dos brasileiros e também acionado como mecanismo de defesa contra agressões verbais e físicas. Interações positivas também foram observadas, mas em número reduzido, frequentemente marcadas por posição de submissão por parte dos bolivianos.

A pesquisa de Soares (2015) investigou a relação entre alunos nacionais e imigrantes peruanos e chineses do ensino fundamental II e apontou baixa interatividade dos imigrantes em sala de aula, que preferiam agrupamentos com colegas da mesma nacionalidade. Fundamentada na revisão bibliográfica, a falta de sensibilidade dos professores em compreender o fenômeno migratório foi apresentada como justificativa.

Rosa (2016), ao investigar a inserção de alunos imigrantes africanos negros no ensino médio, apontou a inexistência de uma política pedagógica que garanta a valorização da cultura dos imigrantes, observando também manifestações de discriminação, preconceito e racismo no ambiente escolar, 
gerando conflitos na relação entre os alunos imigrantes, brasileiros, professores e funcionários da escola.

Deve-se chamar a atenção ao fato de que, nas três pesquisas que tiveram como foco de investigação alunos de diferentes origens (boliviana, peruana, chinesa e africana), a presença de preconceito, discriminação e racismo foram denunciadas.

\section{c) Participação da família}

Em relação à participação da família na escolarização dos estudantes imigrantes, foi encontrada somente a dissertação de Miyahira (2015). A pesquisa teve por objetivo analisar como os professores entendem a participação da família no desempenho escolar desses alunos. Dos resultados apresentados, é interessante destacar que, segundo os profissionais da escola, as famílias bolivianas são muito mais presentes e interessadas no processo escolar dos filhos do que as famílias nordestinas, vistas com muitas dificuldades e incapazes de educar e orientar. E, ainda, das hipóteses iniciais levantadas pelo pesquisador, a que se confirmou totalmente foi a de que os professores não levam em consideração a história e a cultura do aluno migrante-imigrante no seu trabalho pedagógico.

\section{d) Identidade étnica}

A dissertação de mestrado de Aoke (2015) teve um caráter mais histórico ao pesquisar sobre a escolarização da comunidade nipônica do Bairro Parateí, no município de Guararema, estado de São Paulo, no período de 1960 a 1980. A decisão de mantê-la no corpus deste estudo ocorreu em virtude de a dissertação ter como objetivo o estudo da trajetória de escolarização de imigrantes nipônicos e a presença de questões identitárias e culturais. A partir de fontes orais, relatos escritos e fotografias, um dos aspectos comprovados pela pesquisa foi o empenho da comunidade nipônica em manter a escola para seus filhos, demonstrando a importância da escolarização para as famílias e seus descendentes. 


\section{e) Educação profissional}

A pesquisa realizada por Silva (2015) em sua dissertação de mestrado aborda a educação profissional de imigrantes bolivianos em São Paulo, se diferenciando das demais que trataram da escolarização na educação básica.

\section{f) Educação como direito}

A pesquisa de Magalhães (2010) delimitou o estudo ao universo dos imigrantes bolivianos nas escolas públicas. Além da análise documental, a pesquisadora realizou entrevistas com estudantes, mães, pais, professores e funcionários de escolas públicas de São Paulo. O estudo apontou que as escolas pouco promovem a aprendizagem e apresentam relatos de preconceito, discriminação e violência, desafiando a promoção da educação como direito.

O estudo realizado por Waldman (2012) priorizou a discussão sobre o direito à educação escolar com base na análise da legislação nacional (Constituição Federal de 1988, Estatuto da Criança e do Adolescente, Estatuto do Estrangeiro, resoluções, deliberações e pareceres da Secretaria da Educação e Conselhos de Educação do Estado e do Município de São Paulo) e Convenções Internacionais. A partir da análise feita, o estudo apontou a necessidade da aprovação de uma nova Lei de Migrações que inclua a declaração do direito à educação escolar de todos os imigrantes no Brasil, fato que ocorreu somente no ano de 2017, ocasião em que a Lei de Migração Lei no 13.445/2017 foi sancionada pelo Presidente da República.

\section{Dissertações e teses sobre imigração e educação escolar realizadas em portugal}

O levantamento de dissertações e teses foi realizado por meio de consulta às bases de dados das bibliotecas da Universidade Aberta de Lisboa - Repositório Aberto, das bibliotecas da Universidade do Porto Catálogo e também à coleção de Teses do Observatório das Migrações - Alto Comissariado para as Migrações - ACM. 
A busca foi iniciada a partir do termo "imigração" e, pela leitura dos títulos e resumos, foram selecionados os trabalhos relacionados à educação escolar.

Para constituição do corpus da pesquisa, foram utilizados os mesmos critérios de inclusão-exclusão estabelecidos nos levantamentos das dissertações e teses brasileiras. Portanto, não foram incluídos os trabalhos que não tiveram a educação escolar como tema central e também as dissertações e teses com acesso restrito ao material integral.

A partir desses critérios, foram selecionados 20 títulos para análise.

Os estudos foram categorizados em oito grupos, tendo como critério o tema principal da investigação.

\section{a) Gestão, ações e estratégias da escola para promoção da integração dos imigrantes}

Quatro pesquisas foram inseridas neste grupo.

Araujo (2004) investigou a integração de alunos imigrantes no $1^{\circ}$ Ciclo do Ensino Básico. Segundo os professores e alunos, há boa integração e bom rendimento escolar. As mães do leste-europeu relataram a questão da língua como a principal dificuldade de integração em Portugal; já as mães brasileiras mencionaram manifestações de preconceito e discriminação.

Santos (2006) indagou sobre as estratégias da escola para apoiar o sucesso escolar das crianças ciganas. No estudo, a pesquisadora apontou que os alunos ciganos possuem, em geral, dificuldades escolares, especialmente com a língua portuguesa, e alto índice de absenteísmo.

Pontes (2006) investigou como são vividas as relações interétnicas e que ações e estratégias são implementadas por uma escola multicultural. Segundo a pesquisadora, para a maioria dos alunos, a diversidade étnico-cultural não se apresenta como problema, não sendo detectados indícios de discriminação entre eles.

Tavares (2016) propôs investigar a gestão de uma escola reconhecida por órgãos oficiais pela realização de boas práticas. Nas entrevistas com o diretor do agrupamento e com a coordenadora, foram mencionados a 
realização de atividades interculturais, cursos de português para alunos e adultos estrangeiros, projetos e intercâmbios internacionais e ações para o envolvimento das famílias.

Embora as pesquisas apontem a existência de gestão, ações e estratégias das escolas para promoção da integração como, por exemplo, o oferecimento de aulas de língua portuguesa aos imigrantes, ainda persistem tensões entre práticas tradicionais e pedagogias interculturais (ARAUJO, 2004), posições que tendem à assimilação e aos modelos monoculturais (SANTOS, 2006) e ausência de estratégias de apoio à integração das minorias étnicas (SANTOS, 2006; PONTES, 2006). Um ponto que se mostrou consensual entre os pesquisadores foi o pouco conhecimento (ARAUJO, 2004) e despreparo dos professores (PONTES, 2006) como obstáculos a serem superados (TAVARES, 2016), demandando a formação docente para a promoção da educação intercultural.

\section{b) Concepções, representações de alunos imigrantes, pais e professores}

Quatro estudos foram inseridos neste item.

Martins (2005) investigou a integração escolar de crianças imigrantes do leste-europeu e suas representações sobre as escolas portuguesas. Os alunos relataram a existência de aulas de apoio e de Língua Portuguesa, e $63 \%$ disseram ter amigos da mesma nacionalidade. Os pais reconheceram o apoio dado pela escola para supressão das dificuldades dos alunos, mas criticaram a falta de continuidade pedagógica provocada pela mobilidade dos professores.

Rocha (2006) propôs conhecer as concepções e atitudes dos professores perante crianças de diferentes grupos étnico-culturais. A pesquisa foi realizada junto a 125 professores do $1^{\circ}$ Ciclo do ensino público, e os resultados mostraram a necessidade de formação contínua no âmbito da interculturalidade.

Em seu estudo, Gabriel (2007) teve por objetivo investigar as concepções e práticas pedagógicas dos professores, as expectativas dos alunos ciganos sobre a escola e a interação que estabelecem com seus pares. Os 
resultados variam conforme a escola, mas em geral os alunos dizem gostar da escola e dos professores. Pelo discurso dos professores, o pesquisador concluiu que a maioria dos entrevistados admite não trazer a cultura cigana para a sala de aula e desenvolvê-la de forma integrada, permanecendo no modelo monocultural.

A pesquisa de Teófilo (2010) investigou as representações que os professores têm das turmas multiculturais, a que causas atribuem o in/sucesso dos alunos estrangeiros e como se posicionam em relação ao currículo e à Educação Intercultural. A pesquisadora constatou que as representações dos professores são positivas e revelam a conscientização da importância dos fatores culturais, porém, as práticas pedagógicas interculturais - currículo, metodologias, materiais - ainda são realizadas pontual e ocasionalmente.

Das quatro pesquisas, três apontaram a necessidade de formação docente na perspectiva intercultural (ROCHA, 2006; GABRIEL, 2007; TEÓFILO, 2010), tendo em vista as dificuldades dos professores em trabalharem com as diferenças culturais (GABRIEL, 2007), ou porque as práticas interculturais ainda são realizadas de modo pontual ou ocasionalmente (TEÓFILO, 2010).

\section{c) Atitudes em relação aos imigrantes: preconceito e discriminação}

Três trabalhos que discutiram atitudes, preconceitos e discriminação contra alunos imigrantes foram encontrados.

Silva (2007) investigou estereótipos e preconceitos dos alunos de nacionalidade portuguesa em face de alunos imigrantes oriundos do Brasil, Cabo Verde, Ucrânia e China. A hipótese que relaciona o grau de preconceito dos alunos com as variáveis como meios onde vivem (urbano-rural), idade, contato ou não com estrangeiros, nível socioeconômico, diversidade cultural da escola e gênero não foi confirmada. No entanto, confirmou-se a hipótese de que o preconceito/racismo manifesta-se essencialmente de forma sutil e não de forma flagrante.

Botas (2010) analisou as atitudes de crianças em relação ao endogrupo (portugueses) e ao exogrupos (cabo-verdianos, brasileiros e 
chineses). Os resultados apontaram que as crianças manifestaram favoritismo endogrupal, com mais adjetivos positivos atribuídos ao endogrupo do que aos exogrupos, confirmando a hipótese e corroborando investigações já realizadas. No entanto, de modo geral, houve uma avaliação positiva dos exogrupos, pois apenas um quarto dos participantes disse não gostar dos cabo-verdianos e dos chineses, apontando a seletividade na manifestação do preconceito. Os resultados indicam que o favoritismo pelo endogrupo não está diretamente relacionado com a depreciação do exogrupo, uma vez que os participantes não avaliaram negativamente os exogrupos. No entanto, a ausência de avaliação negativa não significa a ausência de preconceito, pois sua manifestação sutil é flagrada pela negação de traços positivos ao exogrupo.

A pesquisa de Robalinho (2016) teve por objetivo investigar as atitudes de jovens secundaristas portugueses em relação à imigração, buscando verificar manifestações de atitudes positivas ou negativas. Participaram do estudo 195 jovens portugueses, de 16 a 18 anos, estudantes do ensino secundário. Os resultados obtidos confirmaram as hipóteses de que os jovens apresentam atitudes positivas em relação à imigração, sendo as raparigas mais favoráveis do que os rapazes.

Deve-se destacar que duas pesquisas apontaram a manifestação sutil de preconceito contra imigrantes, aspecto que merece mais discussão.

\section{d) Implicações da parentalidade / expectativas}

Dois estudos encontrados investigam a importância da família na escolarização de crianças imigrantes.

Mirotshinik (2006) investigou as expectativas de pais do leste-europeu em relação à escolarização dos filhos nas escolas portuguesas. Embora apontem alguns aspectos negativos da escola portuguesa, como a indisciplina nas salas de aula e a fragilidade dos professores portugueses, os entrevistados avaliam a integração dos filhos de forma positiva; relatam que a maioria dos amigos dos filhos são imigrantes e reconhecem que é preciso vencer o isolamento e incentivar amizades com colegas portugueses. 
Independentemente da variável social, os entrevistados revelaram elevadas expectativas em relação aos projetos escolares dos filhos, como o ingresso na universidade.

Gonçalves (2009) investigou a relação entre o envolvimento dos pais e o sucesso escolar de alunos portugueses e originários dos PALOPs. Os resultados confirmaram algumas hipóteses, como melhores percursos escolares são apresentados pelos alunos portugueses em comparação aos colegas africanos; pais com nível socioeconômico mais elevado e com mais escolaridade demonstram maior envolvimento e participação na vida escolar dos filhos.

\section{e) Estudos comparativos}

Dois estudos que comparam os percursos escolares de diferentes grupos étnicos foram incluídos neste grupo.

Pires (2001) comparou o percurso escolar de jovens cabo-verdianos e jovens de origem hindu-indiana, e os resultados apontaram adaptação distinta entre os dois grupos. No caso dos cabo-verdianos, jovens de classe média raramente abandonam a escola, diferentemente dos jovens pobres; jovens de famílias com baixo capital humano vivendo em bairro degradado raramente alcançam o ensino superior. No caso dos hindus, o acesso ao ensino superior é exceção para as duas classes sociais, mas não devido às dificuldades no processo escolar e sim pela presença do fator étnico, que medeia o processo de adaptação escolar.

Casimiro (2006) comparou percursos escolares de descendentes de imigrantes de origem cabo-verdiana em Lisboa e Roderdão. Os dados apontaram que o insucesso escolar é um problema grave dos cabo-verdianos, especialmente em Portugal. Na escola portuguesa, com muitos alunos sem apoio específico, constam elevadas taxas de reprovação e desistência; a maior dificuldade é relacionada à língua portuguesa devido ao uso do crioulo em casa. Na Holanda, embora se registre insucesso escolar, só 3\% dos cabo-verdianos não terminam a escolaridade básica, verificando-se também melhor desempenho dos alunos em Roterdão. Medidas de apoio 
na escola holandesa facilitam a integração como: existência de um professor assistente que fala crioulo e acompanha a adaptação escolar no momento de ingresso do aluno; os pais são chamados a desempenhar papel ativo na orientação do aluno, no contato com professores e nas escolhas dos cursos; o programa escolar contempla um pouco da cultura de cada grupo étnico.

\section{f) Bibliotecas escolares}

Duas dissertações foram dedicadas ao estudo da biblioteca escolar como espaço de promoção do diálogo e da diversidade cultural.

Reis (2011) realiza um estudo sobre o papel da biblioteca e da leitura na promoção de valores como tolerância, solidariedade, cooperação e respeito pela diferença, presentes na educação intercultural, que orienta o sistema educativo português, reconhecendo e valorizando a diversidade como oportunidade e fonte de aprendizagem para todos. A pesquisadora constatou que a experiência realizada com alunos imigrantes do Brasil, Guiné e China possibilitou aos participantes identificarem e reconheceram as diferenças entre si e os outros, e aprenderam a aceitar a diversidade. Por meio da leitura e diálogo sobre as obras, os alunos puderam conhecer outras culturas e valorizá-las, manifestando atitude de tolerância e aceitação.

O estudo de FERREIRA (2012) propôs uma discussão sobre o papel das bibliotecas escolares diante dos desafios postos pela globalização. $\mathrm{O}$ estudo também apontou a biblioteca como um espaço de compartilhamento da cultura de origem, do seu papel como centro formativo e de articulação de todas as áreas de aprendizagem com toda a comunidade educativa.

\section{g) Aprendizagem de Português como Língua Estrangeira}

Sobre este tema foram encontrados apenas dois títulos, embora a discussão sobre o ensino e a aprendizagem da Língua Portuguesa como língua estrangeira tenha comparecido em outras pesquisas.

Cardoso (2005) propôs investigar as interferências linguísticas do cabo-verdiano no processo de aprendizagem do português. Os dados foram 
coletados em escolas portuguesas e em escolas cabo-verdianas. Os dados recolhidos apontam que os tipos de interferência linguística encontrados nos textos produzidos por alunos cabo-verdianos em Cabo Verde e em Portugal são os mesmos, mas em menor quantidade no segundo caso, por estarem mais expostos à língua portuguesa diariamente.

O estudo de Nascimento (2013) investigou a aprendizagem de uma segunda língua por estudantes estrangeiros de mestrado e doutorado em Portugal. O estudo contribuiu para ampliar a compreensão dos processos migratórios, que não são motivados apenas pela precariedade das condições socioeconômicas dos países de origem, mas devendo considerar também os projetos pessoais e as motivações subjetivas.

\section{h) Formação de profissionais para atuar junto a jovens imigrantes}

Embora a formação de profissionais, especialmente professores, tenha sido discutida em muitos trabalhos, foi encontrada somente a dissertação "O trabalho educativo com jovens descendentes de imigrantes e de minorias étnicas: competências profissionais, estratégias e políticas de capacitação", de Silva (2016), que trata da questão como tema central. Foram realizadas entrevistas com os profissionais visando conhecer as competências necessárias no trabalho com jovens descendentes de imigrantes e pertencentes a minorias étnicas.

\section{Algumas comparações entre os estudos realizados no Brasil e em Portugal}

Em relação à nacionalidade dos estudantes imigrantes, pelo que se pode observar, as dissertações e teses produzidas recentemente, tanto nas universidades brasileiras como nas portuguesas, estiveram focadas nos grupos de imigrantes numericamente mais expressivos nos respectivos países.

No Brasil, dos 12 estudos, nove tiveram como sujeitos estudantes bolivianos; um estudo sobre a comunidade nipônica, um estudo sobre peruanos e chineses e um estudo sobre estudantes africanos. A predominância de estudos recentes sobre estudantes bolivianos pode ser explicada 
pelo fato de representarem um dos grupos de imigrantes mais numerosos, principalmente no município de São Paulo.

Em Portugal, os grupos mais estudados foram: cabo-verdianos (oito estudos); brasileiros (sete); países do leste europeu (seis); chineses (cinco); ciganos $^{20}$ (dois)

Diferentemente das pesquisas brasileiras que focavam geralmente em um único grupo de imigrantes em cada investigação, a maioria das pesquisas portuguesas abordou conjuntamente imigrantes de diferentes nacionalidades, com exceção de alguns estudos que se dedicaram a um único grupo, como os cabo-verdianos, nos estudos de Cardoso (2005) e Casimiro (2006), e os ciganos, nas pesquisas de Gabriel (2007) e Santos (2006). Martins (2005) e Mirotshinik (2006) dedicaram seus estudos aos imigrantes do leste europeu, geralmente representados por imigrantes da Ucrânia, Rússia e Moldávia.

Em relação aos temas, alguns foram estudados tanto nas pesquisas brasileiras como nas portuguesas.

$\mathrm{O}$ ensino e a aprendizagem do português como língua estrangeira foi tema de quatro pesquisas brasileiras (MANDALÁ, 2015; GABRIEL, 2016; MOLINARI, 2016; VIEIRA, 2010) e duas pesquisas portuguesas (CARDOSO, 2005; NASCIMENTO, 2013). Comparando os estudos, nota-se que o oferecimento do ensino de português aos imigrantes que estudam nas escolas portuguesas, apoio inexistente aos imigrantes matriculados nas escolas brasileiras, é um dos aspectos que diferenciam as políticas educacionais em Portugal e no Brasil. É interessante notar que, mesmo a interculturalidade sendo uma diretriz na educação portuguesa, portanto contrária às posições assimilacionistas e às práticas pedagógicas monoculturais, a aprendizagem da língua oficial do país receptor é considerada condição indispensável para a integração dos imigrantes.

\footnotetext{
${ }^{20}$ Embora os ciganos não sejam imigrantes, são identificados como minoria étnica que demanda atenção especial na educação escolar. Os brasileiros, cabo-verdianos, ucranianos e romenos são as nacionalidades mais representativas dos estrangeiros com situação legalizada em Portugal (SEF).
} 
A interação entre os alunos estrangeiros e nacionais também foi tema de estudo de pesquisas brasileiras (PONTEDEIRO, 2013; ROSA, 2016; SOARES, 2015) e portuguesas (SILVA, 2007; BOTAS; ROBALINHO, 2016). A denúncia de manifestações de preconceito, discriminação, racismo, xenofobia mostra que a hostilidade ao estrangeiro, ainda que de forma camuflada e sutil (SILVA, 2007; BOTAS, 2010) está presente tanto nas escolas brasileiras como nas portuguesas. $\mathrm{O}$ fato de as manifestações não serem tão explícitas não significa que o preconceito seja mais brando, mas indica apenas a existência de um clima não favorável à discriminação mais aberta (ADORNO, FRENKEL-BRUNSWIK, LEVINSON, SANFORD, 2009), tal como existente em Portugal ou até recentemente no Brasil, diferentemente do que ocorre em países que adotam declaradamente políticas xenofóbicas e contrárias à imigração. Se concordarmos com Adorno e seus colaboradores (2009) que o preconceito decorre muito mais das necessidades psicológicas do indivíduo preconceituoso do que das características das minorias, apenas valorizar a cultura do estrangeiro pode trazer pouco resultado. No entanto, apesar dos limites do esclarecimento frente à irracionalidade dessas tendências psicológicas profundas, o enfrentamento da barbárie deve seguir como objetivo último da educação (ADORNO, 1995, p.119). Desse modo, seguir refletindo sobre as possibilidades da educação escolar em minimizar o preconceito e a discriminação deveria ser uma prioridade nas políticas educacionais fundadas na defesa incondicional dos direitos humanos.

Outro tema investigado nas pesquisas brasileiras e portuguesas foi a participação das famílias no estudo dos alunos imigrantes. A dissertação de Miyahira (2015) foi a única pesquisa brasileira em que o tema foi central, embora outros estudos tenham também abordado as famílias dos alunos imigrantes. A dissertação de Mirotshinik (2006) e a tese de Gonçalves (2009) foram as duas produções portuguesas em que o tema ganhou centralidade. No entanto, é importante ressaltar que a participação das famílias na escolarização dos alunos imigrantes foi muito discutida nos estudos portugueses, sendo apontada como um dos importantes fatores de sucesso/ insucesso escolar, juntamente às condições sociais, culturais e econômicas. 
Tal associação remete à teoria da carência cultural (PATTO, 2015) que, na década de 1970, orientou os estudos americanos sobre o fracasso escolar das minorias daquele país. Pelo menos no Brasil, esse modo preconceituoso e etnocêntrico de acusar as famílias das classes econômica e socialmente marginalizadas pelo fracasso escolar de seus filhos vem sendo denunciado por estudos críticos da educação e da psicologia (PATTO, 2015).

Em relação ao enquadramento teórico-conceitual, foi notável a centralidade do conceito de interculturalidade (RAMOS, 2007, 2009, 2008, 2011) na produção acadêmica portuguesa, sendo que o mesmo não foi observado nas pesquisas brasileiras. Apenas uma breve referência à abordagem multicultural ou ao enfoque / perspectiva intercultural foi encontrada nas pesquisas brasileiras que investigaram o ensino e a aprendizagem do português como língua não materna (VIEIRA, 2010; MANDALÁ, 2015; GABRIEL, 2016). Embora o conceito de interculturalidade não esteja presente nas pesquisas brasileiras sobre a educação de alunos imigrantes, o conceito é vertebral nos estudos sobre a educação dos povos originários no Brasil e outros países da América Latina, como a Bolívia, Argentina e Chile, principalmente no que tange as discussões sobre o ensino das línguas originárias nas escolas. Desse modo, é interessante notar que, em Portugal e outros países da Europa, a educação intercultural é proposta para integrar os estrangeiros à cultura dos países receptores, ao passo que, no Brasil e outros países da América Latina, a interculturalidade é defendida como política de preservação das identidades e culturas originárias.

Do ponto de vista metodológico, foi observado que nas pesquisas brasileiras prevaleceu o método de natureza qualitativa; em relação às pesquisas portuguesas foram utilizados métodos qualitativos, quantitativos e mistos (quali-quanti). A técnica de entrevista semiestruturada foi a mais utilizada tanto por pesquisadores brasileiros quanto pelos portugueses, que utilizaram também questionários e escalas como instrumentos para coleta de dados. Duas pesquisadoras (MANDALÁ, 2015; CARDOSO, 2005), uma brasileira e uma portuguesa, que se dedicaram ao estudo do ensino e aprendizagem do português como língua estrangeira, relataram a análise da produção textual dos alunos imigrantes (bolivianos e cabo-verdianos) como 
procedimento de investigação. $\mathrm{O}$ uso de fontes documentais foi bastante citado por pesquisadores/as brasileiros/as e portugueses/as, mas apenas uma pesquisadora brasileira (AOKE, 2015) relatou o uso de fotografia como fonte de pesquisa. Considerando que a maior parte das pesquisas em ambos os países foi realizada em escolas, a observação, seja participante ou etnográfica, foi também frequentemente utilizada.

\section{O desafio da inclusão escolar dos imigrantes: algumas considerações finais}

Em Portugal, no ano de 2016, 14\% era a taxa de abandono precoce de educação. Apesar dos avanços realizados pelo sistema educacional português, uma proporção significativa de jovens não alcança as competências básicas e reprovam na escola.E, ainda,jovens estrangeiros ou descendentes de imigrantes representam uma parcela significativa dos alunos com insucesso escolar (RAMOS, N., 2008, p.61), desempenho escolar inferior aos nacionais (OLIVEIRA; GOMES, 2017) e retidos (ABRANTES, 2016, p.27).

No Brasil, a exclusão escolar não ocorre somente com os alunos dos grupos minoritários, mas caracteriza-se historicamente como um problema estrutural a ser resolvido (PATTO, 2015). Na história da educação brasileira, várias reformas educacionais tiveram como objetivo a superação do fracasso escolar, mas o problema da escolarização persistiu, principalmente em relação aos alunos das classes populares.

$\mathrm{Na}$ década de 1990, sob forte influência das doutrinas neoliberais ditadas por organismos internacionais, reformas educacionais foram realizadas, mas sem o aumento necessário dos investimentos (FRIGOTTO; CIAVATTA, 2003). A universalização do acesso à educação escolar se restringiu ao ensino fundamental, sem garantir a permanência até o final da educação básica. Em 2010²1, somente 83,3\% dos jovens entre 15 e 17 anos frequentavam a escola; em 2015, mesmo com a tendência crescente

\footnotetext{
${ }^{21}$ Fonte IBGE/Censo Demográfio. Dados obtidos em: http://www.observatoriodopne.org. br/metas-pne/3-ensino-medio/indicadores Acesso em 23 de janeiro de 2018.
} 
de correção da defasagem idade-série, somente 62,7\% dos jovens de 15 a 17 anos estavam matriculados no ensino médio, etapa final da educação básica.

Brasil e Portugal apresentam realidades educacionais distintas, tanto em termos quantitativos como qualitativos, mas apresentam também desafios comuns, como a superação do insucesso e abandono escolar precoce, que demandam mudanças estruturais nos respectivos sistemas de educação.

Embora a imigração esteja presente desde o início da história do Brasil, a produção de pesquisas sobre o direito dos imigrantes à educação escolar é relativamente recente e ainda pouco expressiva. Tal como foi mostrado, as pesquisas encontradas abordam temáticas relacionadas aos desafios presentes na escolarização de imigrantes, apontando questões graves e preocupantes como as manifestações de preconceitos e discriminação. Considerando a prioridade do enfrentamento dessas manifestações, seria importante que mais pesquisadores pudessem investigar e aprofundar as possibilidades da educação escolar e das práticas pedagógicas curriculares contribuírem no enfrentamento do preconceito e da melhor inclusão escolar.

\section{Referências}

ABRANTES, P. A educação em Portugal. Princípios e fundamentos constitucionais. Sociologia,Problemas e Práticas, número especial, 2016, p.23-32.

ADORNO, T. W. Educação e emancipação. Rio de Janeiro: Paz e Terra, 1995.

ADORNO, T. W.; FRENKEL-BRUNSWIK, E.; LEVINSON, D. J.; SANFORD, R. N. Estúdios sobre la personalidad autoritária. In: ADORNO, T.W. Escritos sociológicos II. Madri: Ediciones Akal, 2009.

BAHIA, J. \& SANTOS, M. (Orgs.). Um olhar sobre as diferenças: a interface entre projetos educativos e migratórios. Livro eletrônico. São Leopoldo: Oikos, 2016.

BAENINGER, R. Imigração boliviana no Brasil. Campinas, SP: Nepo/Unicamp; Fapesp, CNPq, Unfpa, 2012.

BRASIL. Lei de Migração no 13.445, de 24 de maio de 2017.

CARVALHO, F. O. Território do significado: a cultura boliviana e a interculturalidade na rede municipal de São Paulo. Revista Diversitas. Dossiê Educação e Direitos Humanos, 2015, 4, 166-223. 
CASA-NOVA, M. J. Migrantes, diversidades e desigualdades no sistema educativo português: balanço e perspectivas. Ensaio: avaliação e políticas públicas em educação, 2005, v.13, n. 47 , p. 181-216.

CYMBALISTA, R; XAVIER, I. R. A comunidade boliviana em São Paulo: definindo padrões de territorialidade. Cadernos da metrópole, 2007, v. 17, p.119-133

ENGUITA, C.M. A face oculta da escola: educação e trabalho no capitalismo. Porto Alegre: Artes Médicas, 1998.

FREITAS, M. C. de; SILVA, A.P. Crianças bolivianas na educação infantil de São Paulo: adaptação, vulnerabilidades e tensões. Cadernos de Pesquisa, 2015, v.45, n.157, p.680-702.

FRIGOTTO, G.; CIAVATTA, M. Educação básica no Brasil na década de 1990: subordinação ativa e consentida à lógica do mercado. Educação \& Sociedade, Campinas, v.24, n.82, p.93-130, 2003. Disponível em: <http://www.cedes.unicamp.br>. Acesso em: 21 abr. 2008.

MAGALHÃES, G.M.; SCHILLING, F. Imigrantes da Bolívia na escola em São Paulo: fronteiras do direito à educação. Pro-Posições, 2012, v.23, n.67, p.43-63.

MAZZA, D.; NORÕES, K. (Orgs.) Educação e migrações internas e internacionais: um diálogo necessário. Jundiaí: Paco Editorial, 2016.

OLIVEIRA, G. C. de. A segunda geração de latino-americanos na cidade de São Paulo: a questão do idioma. Revista Interdisciplinar Mobilidade Humana - REMHU, 2014, v.42, p.213-230.

PATTO, M.H.S. A produção do fracasso escolar: histórias de submissão e rebeldia. São Paulo: Intermeios, 2015.

RAMOS, M. C. P. Impactos demográficos e sociais das migrações internacionais. In: RAMOS, N. (Org.). Saúde, migração e interculturalidade (p. 11-44). João Pessoa: Editora Universitária/UFPB, 2008.

RAMOS, M.C. Globalização e multiculturalismo. Revista Eletrônica Inter-Legere, n.13, p.75-101, jul./dez. 2013.

RAMOS, N. Sociedades multiculturais, interculturalidade e educação. Desafios pedagógicos, comunicacionais e políticos. Revista Portuguesa de Pedagogia, ano 41-3, p.223-244, 2007.

RAMOS, N. Crianças e famílias em contexto migratório e intercultural - desafios às práticas e políticas educacionais, sociais e de cidadania. In: RAMOS, N. (Org.). Educação, interculturalidade e cidadania (p. 53-72). Bucareste: Milena Press, 2008.

RAMOS, N. Diversidade cultural, educação e comunicação intercultural - políticas e estratégias de promoção do diálogo intercultural. Revista Educação em Questão, Natal, v. 34, n. 20 , p.9-32, jan./abr. 2009. 
RAMOS, N. Educar para a interculturalidade e cidadania: princípios e desafios. In: Alcoforado, L. e outros (Orgs.). Educação de adultos: políticas, práticas e investigação (p.189200). Coimbra: Imprensa da Universidade de Coimbra, 2011.

SILVA, S. A. da. Bolivianos em São Paulo: entre o sonho e a realidade. Estudos Avançados, 2006, v.20, n. 57, 157-170.

SILVA, J.; PINEZI, A. K. M. Educação e interculturalidade: um estudo etnográfico de alunos bolivianos na rede pública de ensino paulistana. COLÓQUIO INTERNACIONAL EDUCAÇÃO, CIDADANIA E EXCLUSÃO: didática e avaliação. Anais... 2015, 1, 1-6. Disponível em: http://www.editorarealize.com.br/revistas/ceduce/anais.php. acesso em 12maio2016.

SOUCHAUD, S. A imigração boliviana em São Paulo. Em A. P. Ferreira e cols. (Org.). A experiência migrante: entre deslocamentos e reconstruções. (p.267-290). Rio de Janeiro, RJ: Garamound, 2010.

OLIVEIRA, C. R. \& GOMES, N. Estudantes estrangeiros nos diferentes níveis de ensino. Boletim Estatístico OM, n.3. Coleção Imigração em Números (coord. C. R. Oliveira), Observatório das Migrações. 2017. Disponível em: http://www.om.acm.gov.pt?publicacoes-om/colecao-imigração-emnuemros/boletins-estatistico.

ZANOTTI, L. J. Etapas históricas de la política educativa. Buenos Aires: Editorial Universitária de Buenos Aires, 1972.

\section{Dissertações e teses consultadas no Brasil e em Portugal}

ARAUJO, S.A. Contributos para uma educação para a cidadania: professores e alunos em contexto intercultural. 2004. Dissertação (Mestrado em Relações Interculturais). Universidade Aberta, Porto, 2004.

AOKE, A.H. A escolarização da comunidade nipônica do Bairro Parateí (1960-1980). 2015. Dissertação (Mestrado em Educação). Pontifícia Universidade Católica de São Paulo, São Paulo, 2015.

BOTAS, S. da C.C. Atitudes de crianças em relação aos grupos nacionais. 2010. Dissertação (Mestrado em Relações Interculturais). Universidade Aberta, Lisboa, 2010.

CARDOSO, A.J.G. As interferências linguísticas do caboverdiano no processo de aprendizagem do português. 2005. Dissertação (Mestrado em Relações Interculturais). Universidade Aberta, Lisboa, 2005.

CASIMIRO, E. Percursos escolares de descendentes de imigrantes de origem cabo-verdiana em Lisboa e Roderdão. 2006. Dissertação (Mestrado em Relações Interculturais). Universidade Aberta, 2006. 
FERREIRA C.C.S. Bibliotecas Escolares e Promoção do Diálogo Intercultural: um projeto de investigação-ação num agrupamento de escolas do ensino básico. 2012. Dissertação (Mestrado em Gestão da Informação e Bibliotecas Escolares). Universidade Aberta, Lisboa, 2012.

GABRIEL, A.K.L. Jogo de espelhos: representações sociais de professores de língua portuguesa e de aprendizes bolivianos em contexto multicultural na rede pública de ensino. 2016. Dissertação (Mestrado). Faculdade de Educação. Universidade de São Paulo, São Paulo, 2016.

GABRIEL, F.M.S. O multiculturalismo na escola: o caso dos alunos de etnia cigana. 2007. Dissertação (Mestrado em Relações Interculturais). Universidade Aberta, Lisboa. 2007.

GONÇALVES, L.M.C.R. Escola e imigração na cidade: implicações da parentalidade em adolescentes de diferentes grupos étnicos. 2009. Tese (Doutorado em Ciências da Educação). Universidade Aberta, Porto, 2009.

MAGALHÃES, G.M. Fronteiras do direito humano à educação: um estudo sobre os imigrantes bolivianos nas escolas públicas de São Paulo. 2010. Dissertação (Mestrado). Faculdade de Educação. Universidade de São Paulo, São Paulo, 2010.

MANDALÁ, P. de S. Aspectos fonético-fonológicos e culturais da produção textual de alunos brasileiros e bolivianos de uma escola pública paulistana. 2015. Dissertação (Mestrado em Filologia e Língua Portuguesa). Faculdade de Filosofia, Letras e Ciências Humanas. Universidade de São Paulo, São Paulo, 2015.

MARTINS, A.J.S.A escola e a escolarização em Portugal: representações dos imigrantes da Europa de Leste. 2005. Dissertação (Mestrado em Relações Interculturais). Universidade Aberta, Lisboa, 2005.

MIROTSHINIK, V. Integração e escola em populações imigrantes da ex-URSS. 2006. Dissertação (Mestrado em Ciências da Educação). Universidade Nova de Lisboa, Lisboa, 2006.

MIYAHIRA, E. Relação entre professor e família: um estudo sobre alunos bolivianos e nordestinos na escola pública. 2015. Dissertação (Mestrado em Educação). Pontifícia Universidade Católica de São Paulo, São Paulo, 2015.

MOLINARI, S.G.S. Imigração e alfabetização: alunos bolivianos no município de Guarulhos. 2016. Tese (Doutorado em Educação). Pontifícia Universidade Católica de São Paulo, São Paulo, 2016.

NASCIMENTO, A.I. Migração estudantil e a aprendizagem de uma segunda língua: estudantes estrangeiros em Portugal e suas representações pessoais e socioculturais. 2013. Dissertação (Mestrado em Ciências da Educação). Faculdade de Psicologia e Ciências da Educação. Universidade do Porto, Porto. 2013. 
PIRES, S. A segunda geração de imigrantes em Portugal e a diferenciação do percurso escolar - jovens de origem cabo-verdiana versus jovens de origem hindu-indiana. 2001. Dissertação (Mestrado em Sociologia). Faculdade de Economia. Universidade de Coimbra, Coimbra, 2001.

PONTEDEIRO. L.R. Encontros e confrontos na escola: um estudo sobre as relações sociais entre alunos brasileiros e bolivianos em São Paulo. 2013. Dissertação (Mestrado em Educação). Pontifícia Universidade Católica de São Paulo, São Paulo, 2013.

PONTES, M.J.F.N. A diversidade étnico-cultural na escola. A educação intercultural no ensino básico. 2006. Dissertação (Mestrado em Ciências Sociais e Políticas). Universidade Aberta, Lisboa, 2006.

REIS, T.C.A. A Biblioteca Escolar e a diversidade cultural: a leitura como meio de conhecimento e promoção da diversidade cultural. 2011. Dissertação (Mestrado em Gestão da Informação e Bibliotecas Escolares). Universidade Aberta, Lisboa, 2011.

ROBALINHO, T.F.D. Atitudes em relação à imigração: um estudo com jovens estudantes do ensino secundário. 2016. Dissertação (Mestrado em Psicologia). Faculdade de Psicologia e Ciências da Educação. Universidade do Porto, Porto, 2016.

ROCHA, C.E.F.da. A escola e a diversidade étnica e cultural. 2006. Dissertação (Mestrado em Relações Interculturais). Universidade Aberta, Porto, 2006.

ROSA, E. dos S. A inserção de alunos imigrantes africanos negros na rede estadual de ensino na cidade de São Paulo (2014-2016). 2016. Dissertação (Mestrado em Educação). Pontifícia Universidade Católica de São Paulo, São Paulo, 2016.

SANTOS, M.C.F.E.B.dos. A minoria cigana na comunidade bairreirense: o caso da escolaridade das crianças da Quinta da Mina. Análise dos Processos de inclusão/exclusão. 2006. Dissertação (Mestrado em Relações Interculturais). Universidade Aberta, Lisboa, 2006.

SILVA, B.C.P. da. Trabalho decente, divisão do trabalho e integração regional: educação profissional para imigrantes bolivianos em São Paulo. 2015. Dissertação (Mestrado). PROLAM. Universidade de São Paulo, São Paulo, 2015.

SILVA, C.I.S. Preconceitos etnoculturais: meio rural e meio urbano - contributo para a educação intercultural. 2007. Dissertação (Mestrado em Relações Interculturais). Universidade Aberta, Lisboa, 2007.

SILVA, D.F.S. O trabalho educativo com jovens descendentes de imigrantes e de minorias étnicas: competências profissionais, estratégias e políticas de capacitação. 2016. Dissertação (Mestrado em Ciências da Educação). Faculdade de Psicologia e Ciências da Educação.Universidade do Porto, Porto, 2016.

SOARES, C. de F. Imigrantes e nacionais: um estudo sobre as relações sociais em sala de aula. 2015. Dissertação (Mestrado em Educação). Pontifícia Universidade Católica de São Paulo, São Paulo, 2015. 
TAVARES, P.F.O. A gestão da escola na promoção da interculturalidade no agrupamento. 2016. Dissertação (Mestrado em Administração e Gestão Educacional). Universidade Aberta, Lisboa, 2016.

TEÓFILO, T.M.F.I. Representações e práticas de professores dos $2^{\circ}$ e $3^{\circ} \mathrm{CEB}$ em turmas multiculturais: contributos para um elogio da transformação. 2012. Dissertação (Mestrado em Relações Interculturais). Universidade Aberta, Lisboa, 2012.

VIEIRA, M.E. Ensino e aprendizagem de português língua estrangeira. Uma aproximação sociocultural. 2010. Tese (Doutorado). Faculdade de Educação. Universidade de São Paulo, São Paulo, 2010.

WALDMAN, T. C. O acesso à educação escolar de imigrantes em São Paulo: a trajetória de um direito. 2012. Dissertação (Mestrado). Faculdade de Direito. Universidade de São Paulo, São Paulo, 2012. 



\section{Sobre as organizadoras}

\section{Rosa Martins Costa Pereira}

Pedagoga. Especialista em Metodologia do Ensino Superior e em Gestão Escolar. Mestre e Doutora em Geografia. Pesquisadora do Grupo de Pesquisa em Educação, Filosofia e Tecnologias GET/IFRO, no qual coordena o núcleo de estudo de Educação e Migração. Técnica em Assuntos Educacionais do Instituto Federal de Rondônia - Reitoria.

Email: rosa.martins@ifro.edu.br

\section{Solimária Pereira Lima (Organizadora/Autora)}

Mestre em Letras pela Universidade Federal de Rondônia. Especialista em Língua Portuguesa e Literatura Brasileira pela UCAM. Licenciada em Letras pela UNIR. Técnica em Assuntos Educacionais no IFRO e Advogada, Pesquisadora do GET (Grupo de Pesquisa em Educação, Filosofia e Tecnologia).

Email: solimaria.lima@ifro.edu.br

\section{Zuíla Guimarães Cova dos Santos}

Doutora em Geografia pela Universidade Federal do Paraná - UFPR. Mestre em Ciências da Linguagem pela Universidade Federal de Rondônia - UNIR. Professora do Departamento de Ciências da Educação - UNIR. Desenvolve pesquisa na área da educação, escolas em área de fronteira internacional, cultura, formação de professores e migrações.

E-mail: zuilagc@gmail.com 



\section{Sobre os/as autores/as}

Gislaina Rayana Freitas dos Santos - Formada em Pedagogia. Graduanda em Serviço Social. Pós-graduada em Metodologia do Ensino Superior em EaD pela FAEL. Pós-graduanda em História e Cultura Afro-brasileira e Africana. Mestranda em Educação pelo Programa de Pós-graduação Stricto Sensu em Educação - Mestrado Acadêmico em Educação pela UNIR.

Beatriz Lima Costa - Graduada em psicologia pela Universidade Federal de Roraima. Mestre em Psicologia pela Universidade Federal de Rondônia com pesquisas na área de psicologia escolar e processos educativos.

Luanna Freitas Johnson - Psicóloga. Professora no Departamento Acadêmico de Ciências da Educação na Universidade Federal de Rondônia - Campus de Guajará Mirim. Mestre em Psicologia (UNIR). Doutoranda em Educação (UEM/UNIR).

Iracema Neno Cecilio Tada - Doutora em Psicologia pela Universidade de São Paulo. Mestre em Psicologia pela Universidade de Brasília. Graduada em Psicologia pela Universidade de São Paulo. Professora-associada do curso de Psicologia e do Programa de Pós-Graduação em Psicologia da Universidade Federal de Rondônia. Líder do Grupo de Pesquisa "Centro de Pesquisa em Formação da Pessoa”. Membro da Associação Brasileira de Psicologia Escolar e Educacional e do GT "Psicologia e Políticas Educacionais” da Associação Nacional de Pesquisa e Pós-Graduação em Psicologia. E-mail: iracematada@gmail.com

Ednalva Oliveira Silva - Formada em Pedagogia pela Universidade Federal de Rondônia - UNIR e Psicologia pela Universidade Federal da Bahia - UFBA. Pós-graduada em Potenciais da Imagem: recursos multimidiáticos, fotografia, vídeo, computador, em Ciências Humanas pela Universidade Federal da Bahia e em coordenação pedagógica pela Universidade Federal de Rondônia - UNIR. 
Geiza dos Santos Mendonça - Graduada como Tecnóloga em Gestão Pública/IFRO. Pesquisadora do Grupo de Pesquisa em Educação a Distância - GPED/IFRO. Departamento de Educação a Distância do IFRO/ DEPEaD. Pesquisadora Colaboradora do Grupo de Pesquisa em Educação, Filosofia e Tecnologias - GET/IFRO GEOPEDAGOGIA/IFRO.

Iza Reis Gomes Ortiz - Doutora em Sociedade e Cultura na Amazônia pela Universidade Federal do Amazonas - UFAM. Mestre em Letras: Linguagem e Identidade pela Universidade Federal do Acre - UFAC. Professora de Língua Portuguesa e Literatura do Instituto Federal de Rondônia - IFRO. E-mail: iza.reis@ifro.edu.br

Glauciane Sanches da Silva - Bacharela em Gestão Ambiental pela Universidade Federal de Rondônia. Acadêmica do Curso de Licenciatura em Pedagogia $-4^{\circ}$ período pela Universidade Federal de Rondônia.

Rosenete Salvatierra Marinho Niederauer - Acadêmica do Curso de Licenciatura em Pedagogia - $4^{\circ}$ período pela Universidade Federal de Rondônia.

Elaine Márcia Souza Rosa - Pedagoga pela Universidade Luterana do Brasil - ULBRA. Especialista em Supervisão, Orientação e Gestão Escolar pela Faculdade Santo André - FASA. Professional of Life Coaching pela Sociedade Latino Americana de Coaching - SLAC. Pesquisadora do Grupo de Pesquisa em Educação, Filosofia e Tecnologias GET/IFRO. Assistente de Alunos do Instituto Federal de Rondônia - Reitoria. Email: elaine.marcia@ifro.edu.br

Cláudia Gonçalves Barroso - Acadêmica do Curso de Pedagogia na Universidade Federal de Rondônia - Campus de Guajará-Mirim. Atuou como estagiária na docência do Programa Institucional de Bolsas de Iniciação à Docência (Pibid). Interessa-se por Orientação Educacional.

Luanna Freitas Johnson - Psicóloga. Professora no Departamento Acadêmico de Ciências da Educação na Universidade Federal de Rondônia - Campus de Guajará Mirim. Mestre em Psicologia (UNIR). Doutoranda em Educação (UEM/UNIR). 
Thaís Alicea Brito - Acadêmica do Curso de Pedagogia na Universidade Federal de Rondônia - Campus de Guajará-Mirim. Atuou como bolsista do Programa Institucional de Bolsas de Iniciação à Docência (Pibid). Residente do Programa Residência Pedagógica. Interessa-se por Processos de Aprendizagem, Educação Especial e LIBRAS.

Irisneide Moraes da Silva Araújo - Graduada em Pedagogia, licenciatura plena pela Universidade Federal de Rondônia - UNIR. Pós-graduada em Supervisão, Orientação e Gestão Escolar com ênfase Psicologia Educacional. Psicopedagogia Clínica e Institucional.

Zuíla Guimarães Cova dos Santos - Doutora em Geografia pela Universidade Federal do Paraná - UFPR. Mestre em Ciências da Linguagem pela Universidade Federal de Rondônia - UNIR. Professora do Departamento de Ciências da Educação - UNIR. Desenvolve pesquisa na área da educação, escolas em área de fronteira internacional, cultura, formação de professores e migrações.

Rosa Martins Costa Pereira - Pedagoga. Especialista em Metodologia do Ensino Superior e em Gestão Escolar. Mestre e Doutora em Geografia. Pesquisadora do Grupo de Pesquisa em Educação, Filosofia e Tecnologias GET/IFRO, no qual coordena o núcleo de estudo de Educação e Migração. Técnica em Assuntos Educacionais do Instituto Federal de Rondônia Reitoria.E-mail: rosa.martins@ifro.edu.br

Cledenice Blackman - Licenciada e Bacharela em História. Bacharela em Biblioteconomia. Mestra em História e Estudos Culturais e Doutoranda em Educação pela Universidade Estadual Paulista “Júlio de Mesquita Filho” - UNESP/Marília, sob a orientação da Prof a Dra. Tânia Suely Antonelli Marcelino Brabo. Bibliotecária do Instituto Federal de Educação, Ciência e Tecnologia de Rondônia - IFRO. Pesquisadora do Grupo de Pesquisa em Educação, Filosofia e Tecnologias - GET/IFRO.

E-mail: cledenice.blackman@ifro.edu.br 
Patrícia Pereira da Silva - Tecnóloga em Gestão Pública e licencianda em Letras Português e suas Respectivas Literaturas. Pesquisadora do Grupo de Pesquisa em Educação, Filosofia e Tecnologias GET/IFRO.

E-mail: patthypds@gmail.com

Samuel Dorvillus - Pedagogo e Especialista em Ensino de Língua Inglesa e Francesa pela Escola Normal dês Gonaives Saint-Pierre Claver-Artibonite. Graduado em Tecnologia de Gestão de Recursos Humanos/ UNIRON. Especialista em Gestão de Pessoas e Psicologia Organizacional. Pesquisador do Grupo de Pesquisa em Educação, Filosofia e Tecnologias GET/IFRO.

E-mail: dorvillussamuel@gmail.com

Budiene Martins da Silva - Licenciado em Letras/Inglês. Especialista em Metodologia do Ensino Superior. Graduação em andamento em Letras/ Francês. Pesquisador do Grupo de Pesquisa em Educação, Filosofia e Tecnologias GET/IFRO.

E-mail: buddy_martins@yahoo.com.br

Natália Ramos - Professora Associada da Universidade Aberta (UAb), Lisboa, Portugal, onde é docente na Graduação e Pós-Graduação. Coordenadora Científica do Centro de Estudos das Migrações e das Relações Interculturais/CEMRI/UAb. Investigadora Responsável do Grupo de Investigação Saúde, Cultura e Desenvolvimento. Doutora e Pós Doutora em Psicologia Clínica e Intercultural, Universidade de Paris V, Sorbonne e especializada em Aconselhamento Psicológico pela mesma Universidade. Formação especializada em Antropologia Fílmica, Escola Prática de Altos Estudos, Sorbonne, Paris. Psicóloga. Tem publicado, investigado e coordenado projetos de pesquisa nacionais e internacionais e orientado investigações de Mestrado, Doutorado e Pós Doutorado, em particular sobre questões interculturais, migratórias, educacionais, psicossociais, clínicas e de saúde.

E-mail: Maria.Ramos@uab.pt 
Maria da Conceição Pereira Ramos - Doutora e Mestre em Ciência Económica- Economia dos Recursos Humanos, pela Universidade de Paris I, Sorbonne, França. Professora da Faculdade de Economia (FEP) da Universidade do Porto (UP), Portugal. Investigadora do Centro de Estudos das Migrações e das Relações Interculturais (CEMRI/UAb). Coordenadora de Programas Europeus de Mobilidade e Formação. Membro do Conselho Editorial de Revistas de Educação. Pesquisa e docência (graduação e pós-graduação) nas áreas das migrações internacionais, educação, trabalho, saúde, interculturalidade, políticas sociais, desenvolvimento sustentável. E-mail: cramos@fep.up.pt

Lineu Norio Kohatsu - Mestre e Doutor pelo Programa de Pós-Graduação em Psicologia Escolar e do Desenvolvimento Humano do Instituto de Psicologia da Universidade de São Paulo (USP). Realizou pós-doutorado na Faculdade de Economia (FEP) da Universidade do Porto (UP), Portugal.É docente do Departamento de Psicologia da Aprendizagem, do Desenvolvimento e da Personalidade do Instituto de Psicologia-USP. Integra o grupo de pesquisa Migrações e Identidade/Centro de Estudos Rurais e Urbanos (CERU) (diretório CNPq) da Faculdade de Filosofia, Letras e Ciências Humanas/USP. É pesquisador do Programa Ano Sabático do Instituto de Estudos Avançados - IEA/USP. Realiza estudos sobre educação, imigração, xenofobia e sobre o uso de fotografia e vídeo em pesquisas.

E-mail: lineu@usp.br 
